UC-MRLF



(n)

C 2 B I 4003 


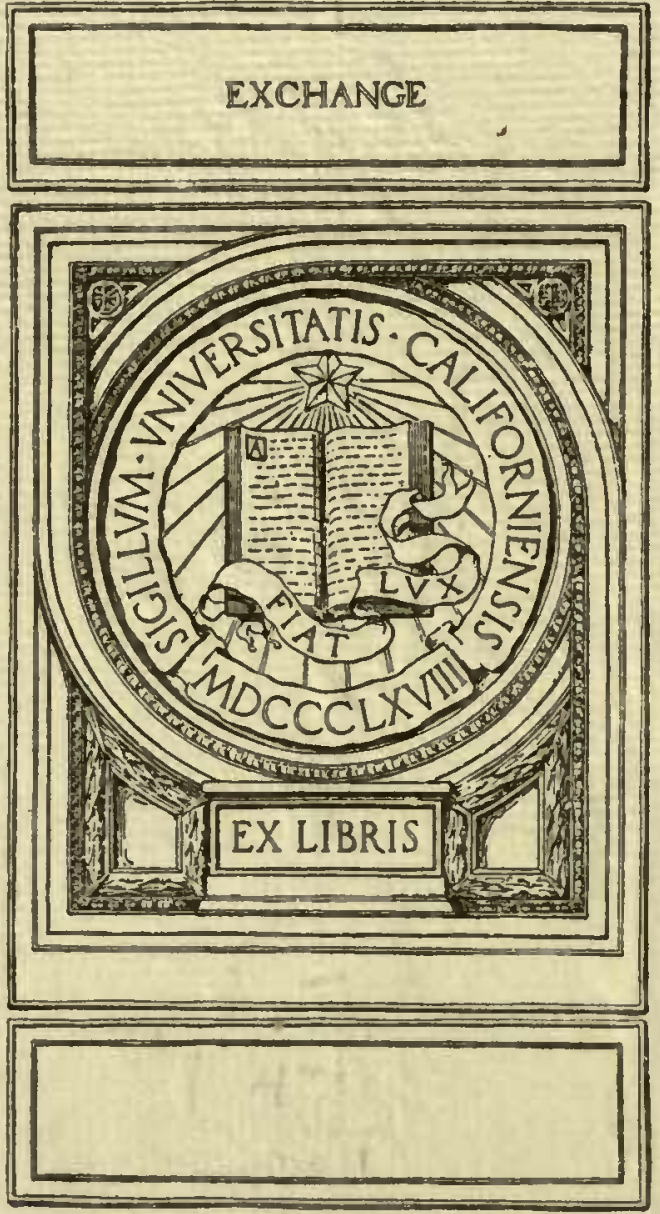






\section{MEMOIRS}

\section{OF THE \\ NEW YORK STATE MUSEUM}

VOL. I. N0. 1. OCT., 1889

\section{THE DEVELOPNENT' OF SOME SLLURIAN BRACHIOPODA \\ WITH EIGHT PLATES \\ BY}

ALBANY

UNIVERSITY OF THE STATE OF NEW YORK

1889 



\section{TABLE OF CONTENTS}

TITLE PAGE,

TABLE OF CONTENTS,

INTRODUCTION, : . . . . . . . . . . . . . . $5^{-12}$

DISCUSSIONS OF THE SPECIES, . . . . . . . . ${ }^{1}{ }^{2}-95$

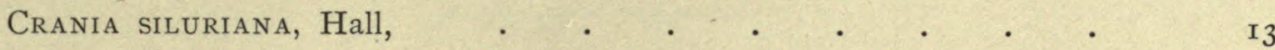

Orthis Elegantula, Dalman, . . . . . . . . $13^{-17}$

ORTHIS HYBRIDA, Sowerby, . . . . . . . . . .

Strophomena RHOMboidalis, Wilckens, . . . . . . $18-22$

Streptorhynchus subplanum, Conrad, . . . . . . ${ }^{23} 3^{-25}$

Strophonella striata, Hall, . . . . . . . . $25^{-29}$

Streptis waldronensis, Miller and Dyer, . . . . . 30-31

Eichwaldia Reticulata, Hall, . . . . . . . . $3^{1-32}$

Anastrophia internascens, Hall, . . . . . . . $32-34$

Rhynchonella acinds, Hall, . . . . . . . . . $35-36$

Rhynchonella neglecta, Hall, . . . . . . . . 37-39

Rhynchonella whitit, Hall, . . . . . . . . 39-42

Rhynchonella indianensis, Hall, . . . . . . . $44^{2-47}$

Rhynchotreta cuneata, (Dalman) var. americana, Hall, . . . 47-5I

Atrypa Reticularis, Linnæus, . . . . . . . $55^{\mathrm{I}-55}$

Retzia evax, Hall, . . . . . . . . . $55-6 \mathrm{I}$

Retzia sobrina, sp. n., . . . . . . . . . 6 i -64

Celospira disparilis, Hall, . . . . . . . . . $64-67$

Meristella rectirostra, Hall, . . . . . . . . $67-69$

Meristina nitida, Hall, . . . . . . . . . . $70-72$

Whitfieldia maria, Hall, . . . . . . . . $73-75$

Spirifer crispus, Hisinger, . . . . . . . . . $75-77$

Spirifer Crispus, var, Simplex, Hall, . . . . . . $\quad 75-77$

Spirifer bicostatus, (Vanuxem) var. petilus, Hall, . . $\quad 75-77$

Spirifer Radiatus, Sowerby, . . . . . . . . . $77-8 \mathrm{I}$

SUMMARY OF DEVELOPMENTAL CHANGES, . . . . . . . . $\quad 83-95$

PLATES AND EXPLANATIONS, . . . . . . . . . I-VIII 97 



\section{THE DEVELOPMENT OF SOME SHLURIAN BRACHIOPODA}

By John M. Clarke and Charles E. Beecher*

\section{INTRODUCTION}

The fossil faunas of our rock systems rarely furnish material for tracing the individual development of any of the contained species. Much will doubtless be done toward ascertaining such development when large collections from suitable localities have been studied with this object in view, and when the number of new species discovered and described each year approaches a minimum. We have a comparatively full and satisfactory account of the development of the individual organism in several species of trilobites, as given in the works of Barrande, Walcott, Ford and Matthew; Hyatt, Branco, Mojsisovics and others have demonstrated the developmental characters of many of the fossil cephalopods, and Verworn has elicited similar facts from certain extinct species of ostracoda. Farther than this but little has been attempted, although the field is a most extensive, important, and inviting one.

As a general rule, the treatment of fossil organisms has rested mainly

* The order of the names of the authors of this paper is without significance. The work was equally divided and jointly reviewed. 
with geologists having more or less of a zoölogical training, and the principal aim has been to present the faunal aspects of each horizon for the purpose of chronological identification. This process has frequently become so involved with the imperfect description of species, that the systematic zoölogist or paleontologist is unable to make any use of a large proportion of the species as a means of studying their taxonomic relations or their structural affinities with each other and with recent forms.

Each revision of a group of fossil animals has resulted in the establishment of numerous specific and generic synonyms. Many of these are owing, of necessity, to the imperfection of the material, and many names which are finally relegated as synonyms, have been created under a misconception of the full significance of age, sex, habitat and condition of preservation. Additional confusion often results from the inclusion, in a generic or specific description, of characters which pertain not alone to a normal individual, but interspersed with certain normal adult features are those belonging to various stages of morphological development and peculiarities arising from accident, disease and impoverished conditions.

In the case of rare species, or of meager material belonging to common forms, it is to be noticed that assertions regarding specific and generic characters are usually very positive; while, with an abundance of specimens representing many stages of growth and the extremes of individual variation, the descriptions are qualified, the latitude of genera and species is extended, and the points of relationship with allied forms are multiplied, thus binding a group of organisms into comparative uniformity, without anomalous differences such as often occur where the dividing lines are rigidly drawn.

During the years $1878-79$, the collection of fossils made from the Niagara group at Waldron, Indiana, for the New York State Museum, was studied and arranged by one of the writers. This is probably the largest collection yet brought together from that celebrated locality, and 
some conception of its size may be obtained from the fact that, when received, it weighed about seven tons. At the time mentioned, all the mature specimens were selected and specifically separated. Many immature forms were also reserved and used in arranging the series prepared for exhibition in the State Museum. It was designed to represent in the arrangement, each species by a series of specimens showing the gradations of size and form from mature individuals down to as young and small specimens as could be found. Abnormal examples, also, were reserved and grouped with them. It was the intention of the writers to accompany this memoir with photographic illustrations of these series, representing each species here discussed, but it has not been found wholly feasible, and the illustrations are largely restricted to the presentation of the immature and adult conditions of growth, with the exception of the several series which are given on plate 8 .

The product obtained from washing the slabs, was preserved and passed through sieves to assort the material into different grades of fineness. It was found that these washings contained a great number of partially developed shells, and it is from them that the extremely young brachiopods, treated of in the present paper, have been derived. The writers have carefully examined all the residue of these washings and have picked out about fifty thousand specimens, most of which are less than five millimeters in length, and many have a length of not more than one millimeter. After all the imperfect and badly preserved individuals were rejected, there still remained more than fifteen thousand inchoate individuals.

The sediments at Waldron consist of fine calcareous shales, weathering into clays. A stratum of Niagara limestone overlies the shales at this locality, but none of the fossils derived from this limestone have been used in the preparation of the present paper, and so far as known, it has a comparatively different fauna and does not furnish such material as is here 
described. The calcareous matter in the shales consists almost entirely of fossils and fragments of fossils, principally branches of corals and bryozoa, segments of crinoid columns, and broken crinoid plates. The brachiopoda are all calcareous and the original shell structure is more or less preserved, depending upon the absence or presence of pyrite.

The occurrence in such great numbers of immature shells in these deposits may be explained by the luxuriant fauna which flourished in this Niagara basin, by the quiet seas of this region and by the rapid sedimentation of the shales. The richness of the material is shown by the great profusion of specimens representing the sponges, corals, crinoids, bryozoa, brachiopods, gastropods, annelids and crustaceans, comprising altogether about one hundred and fifty'species. The lamellibranchs and cephalopods were also doubtless abundant, but the conditions existing for the preservation of their remains were not favorable, probably on account of the composition of their shells, and but sixteen species have been noted. That the fauna was protected from excessive storms and the action of sea currents, is evinced by the usual perfection of the fossils. Some of the crinoids are unbroken and remain attached by their roots, retaining their arms in place ; also, large colonies of delicate branching corals and bryozoa still preserve their unity. The specimens were rapidly buried in the soft calcareous mud and show none of the eroding or disintegrating action of the water, such as would have been produced had they lain for any considerable period unprotected on the sea bottom. It is true that many specimens are incrusted with bryozoa, annelids, cranias and other fixed and incrusting forms, but the majority of these seem to have flourished during the life of their hosts.

Besides the embryonic brachiopoda occurring in these shales, there are other classes represented by immature forms, notably the gastropoda and crinoidea. These, with the brachiopoda, embrace almost all the young forms found. The small gastropods are of little interest, on account of the 
limited number of species, and because they undergo no important modification in their subsequent growth, and merely represent the apical portion of mature individuals. Among the crinoids, the modifications of form and structure from the embryo state to maturity are more profound and essential, although the material is not sufficiently complete to furnish any very important results.

It is necessary to state that nearly all our observations on the development of the brachiopoda are based upon the study of the material derived from a single locality, and some of the minor deductions may not apply, in every case, to the individuals of the same species found in other regions. The writers have also refrained, except when essential to the proper exposition of a species, from entering into details of synonymy or generic controversy as to the correct reference of the species. This course is considered advisable, from a desire not to introduce any discussions alien to the descriptions of the developmental changes in these organisms. Aside from this, it is believed that a number of important facts are here added to the knowledge of the brachiopoda, and that many of them will be found to be of general application. The investigation has also resulted in elucidating several obscure and anomalous features of the shell and of the cardinal area, which appear in their proper place in the description of the species and in the general summary.

The following list includes all the species of brachiopoda which, up to this time, have been described from the shales at Waldron, Indiana, and comprises forty-two species and varieties, ascribed to twenty-four genera. It also shows whether material has been obtained which furnishes data for tracing the developmental changes.

The majority of the species which have afforded no young specimens are rare forms even in their adult state. Among the actually abundant species of which there are no means accessible of tracing the life-history, Rhynchonella stricklandi is a noticeable example, and it is really the only 
common species which has afforded no young shells. Whitfieldia maria, another abundant form, furnishes a series which is notably incomplete, as the youngest individual observed, which can with certainty be referred to it, has a length of $6 \mathrm{~mm}$. Likewise, the inarticulate species have yielded alnost no immature specimens.

List of the Brachiopoda occurring in the Niagara shales at WALDRON, INDIANA

Crania silutiana, Hall, . . . . . One embryo.

Crania setifera, Hall, . . . . . No young shells obtained.

Crania spinigera, Hall, . . . . " . " " "

Lingula gibbosa, Hall, . . . . . " “ “

Pholidops ovalis, Hall, . . . . " . "

Orthis hybrida, Sowerby, . . . Numerous inchoate specimens.

Orthis elegantula, Dalman, . . . . " . " .

Orthis subnodosa, Hall, . . . . No young shells obtained.

Orthis biloba, Linnæus, . . . . " " " "

Streptorhynchus tenue, Hall, . - . . " " " "

Streptorhynchus subplanum, Conrad, . . Full series, showing development.

Strophomena rhomboidalis, Wilckens, . " "

Strophodonta profunda, Hall, . . . No young shells obtained.

Strophonella striata, Hall, . . . . Full series, showing development.

Strophonella semifasciata, Hall, . . . . No young shells obtained.

Leptena transversalis, Dalman, . . " " " .

Streptis waldronensis, Miller and Dyer, . One embryo.

Chonetes nova-scotica, Hall, . . . No young shells ubtained.

Chonetes unduluta, Hall, .

Eichwaldia reticulata, Hall,

Young shells not rare.

Pentamerus fornicatus, var., Hall, . . No young shells obtained.

Anastrophia internascens, Hall, . . Young shells not rare.

Rhynchonella neglecta, Hall, . . . Young shells very abundant.

Rhynchonella acinus, Hall, . . " " " "

Rhynchonella indianensis, Hall, . . . " " " " "

Rhynchonilla whitiz, Hall, . . . " " "

Rhynchonella stricklandi, Sowerby, . . Mature form abundant; no young shells obtained.

Rhynchotreta cuneata, Dalman, . . Young shells common. 


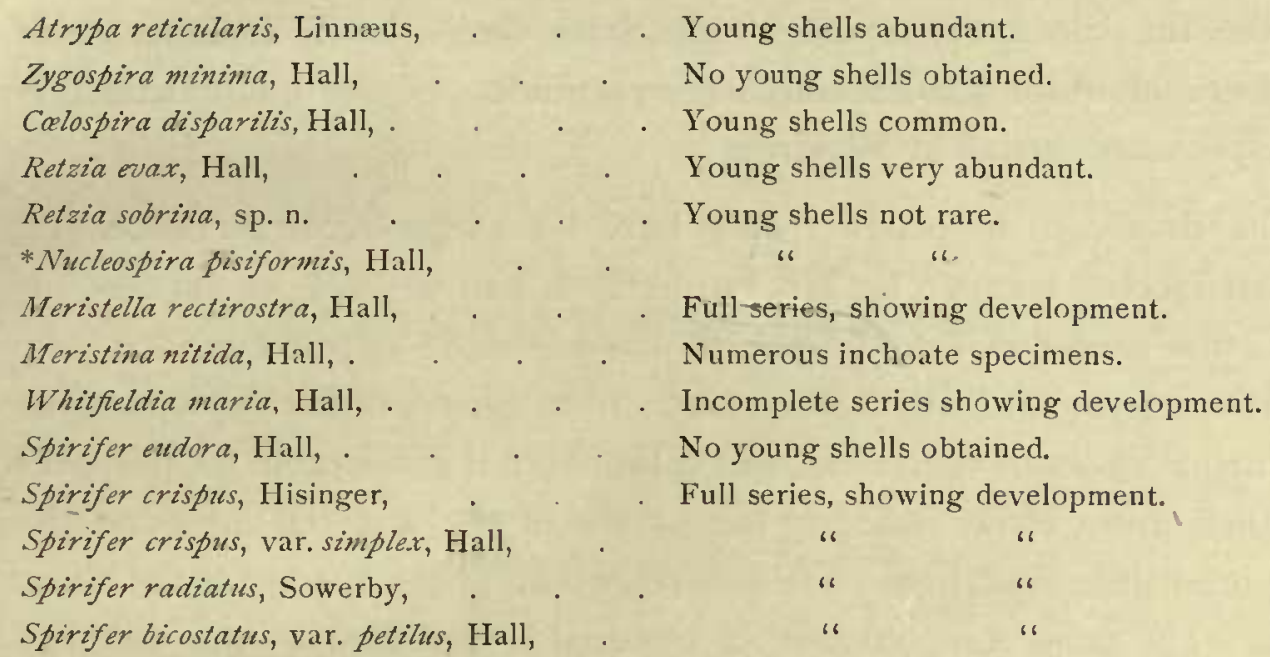

The method of illustration which has been adopted is one which seems most readily to furnish a means for comparison of characters. The embryonic shells are represented as enlarged, usually to the size of an adult, and accompanying the enlargements are natural size representations of the final result of normal growth. Where the mature forms have been too minute to show satisfactorily the details of structure, both the developmental stages and full grown shell have been enlarged to a convenient size. Thus the incipient stages and mature specific form are presented together. In the delineation of special features, such as the hinge, we have sometimes enlarged the earlier phases to a size corresponding with the same structure in the mature form, or have increased all on a uniform scale, so that both the particular characters and their comparative size are presented.

The enlarged drawings have been made by the writers, principally from the microscope; the camera lucida was employed to ensure accuracy in outline. The illustrations of the mature specimens are largely taken from the Twenty-eighth Annual Report of the New York State Museum

* The mature characters of this species are assumed so early, that the youngest forms observed show no important differences from the adult. On this account, no discussion of its characters is given in the ensuing pages. 
and from the Eleventh Report of the State Geologist of Indiana, which may be consulted for a more ample representation of the adult characters of the species occurring at Waldron.

The drawings on plates $\mathrm{I}$ to 7 have been reproduced on stone, in a most satisfactory manner, by Mr. Philip Ast, and we wish to express our appreciation of the skill and labor he has bestowed upon the work. The illustrations given on plate 8 were made from photographic reproductions of the actual series of specimens, and, although not serviceable for purposes of detailed study, show distinctly the nature of the material used and the almost insensible gradations obtained, representing the life-history of these species. The same completeness of material is furnished by the majority of forms described in the following pages.

The arrangement of the subject-matter in the discussions of the species may not seem to be in accordance with the usual method employed in tracing the life-history of organisms. In this case we are dealing with fossil organisms and, in order to insure accuracy of results, it is necessary to begin with the known and established facts and gradually descend to to minute and strange forms, thereby connecting the extremes of growth. Under the caption, "Developmental Changes," we have, however, endeavored to trace the history of each feature of the shell, from its inception to maturity. 


\title{
DISCUSSIONS OF THE SPECIES
}

\author{
Crania siluriana, Hall, i 863
}

Plate I, Figs. I, 2

\footnotetext{
- Hall. Twenty-eighth Ann. Rept. N. Y. State Mus. Nat. Hist., p. 148, pl. 21, figs. 3-7. 1879.

_- - Hall. Eleventh Ann. Rept. State Geol. Indiana, p. 282, pl. 21, figs. 3-7. 1882.
}

But a single embryo of this species has been found in all the material examined. It is of an incipient stage of growth, measuring but $1 \mathrm{~mm}$. in height, and $1.5 \mathrm{~mm}$. across the aperture. Compared with the mature form, the average size of which is about $9 \times 20 \mathrm{~mm}$., it shows a relatively greater elevation and a more regularly conical form. Otherwise, all the few essential characters of the adult shell are present at this early age.

\section{Orthis elegantula, Dalman, i 827 \\ Plate I, Figs. 3-II}

- - Hall. Twenty-eighth Rept. N. Y. State Mus. Nat. Hist., p. 150 , pl. 21, figs. 11-17. 1879.

— - Hall. Eleventh Ann. Rept. State Geol. Indiana, p. 285, pl. 21, figs. 11-17. 1882.

Both the species of Orthis occurring at Waldron (O. elegantula and O. hybrida) are very abundant. In the later stages of growth, the former species is readily distinguished from the latter by its flatter and shallower dorsal valve and deeper ventral valve, features which usually hold good for purposes of discrimination; but in extremely early stages of growth, the nearly equivalve form of the shell makes the separation of the species very 
difficult, perhaps even impossible. Between the dimensions of $.5 \times .75 \mathrm{~mm}$. and $18.5 \times 18 \mathrm{~mm}$. (which is a little in excess of average mature size), we have found every gradation in size and development. The minute shell which serves as a starting point for the series may quite as well be taken as the incipient shell of Orthis hybrida, as both its valves have the same depth, while the cardinal areas and beaks show the same character of development. As there can be no doubt of this fact, it becomes impossible to determine whether a given embryo, could it have grown to maturity, would have developed into $O$. hybrida or O. elegantula. Until the embryos reach a size of 2 or $2.5 \mathrm{~mm}$. in length, their specific value is undeterminable, and the specific individuality of $O$. elegantula can be established only with the increasing depth of the ventral valve from this point upward toward adolescence.

Unless our observations are at fault, and they have been made with great care, evidence here is very positive, that the diagnostic characters of species of this genus may not be assumed until the earlier stages of the existence of the shell have passed.. Indications of similar character are found among the species of Rhynchonella and Spirifer. The importance of the fact is apparent and its significance will be appreciated.

\section{SPECIFIC CHARACTERS}

Mature Form (plate 1, figs. 10-12a). Outline subcircular; hinge line short, about one-half the width of the shell, straight.

Ventral valve elevated along the dorsum, which is arched and slopes more rapidly toward the lateral than toward the anterior margin ; greatest width below the hinge-line, about half-way down the valve. Beak full, arched, incurved, and projecting over the cardinal area sufficiently to conceal the foramen. Cardinal area broadly triangular, low, incurved; foramen triangular; deltidial plates absent.

Dorsal valve shallow, nearly flat, slightly rounded over the umbo, but depressed toward the margins. A sharply defined sinus starts near the 
apex, but by widening with the growth of the shell, it becomes nearly obsolete before reaching the margins. Cardinal line straight ; cardinal area narrow, elongate triangular; beak inconspicuous. Foramen triangular and filled by a tripartite cardinal process which passes into, without filling the foramen of the opposite valve.

Surface of the shell closely covered by fine thread-like strix which increase by intercalation; concentric growth-lines rare, except near the margin where they appear as wrinkles.

- Incipient Form (plate 1 , figs. $3,3^{a}$ ). The initial shell of our series, measuring $.5 \mathrm{~mm}$. in length and $.75 \mathrm{~mm}$. in width, has valves of equal depth and convexity. The length of the hinge-line nearly equals the greatest width of the shell. The cardinal area is high, and equally elevated on each valve. Beaks erect; foramina large, triangular, open and marginate. On the ventral valve is a single median stria, representing the dorsum of the mature shell, accompanied by one and indications of a second on each of the lateral areas, making three (i. e., five) strix on the valve. On the dorsal valve a low and wide median depression is apparent, bounded by two central strix, these being accompanied by two accessory pairs upon the latera, making six strix in all. It is very probable that this form represents the actual initial stage in the development of the shell, and if this is the case, the inception of the plications on the surface, which become so numerous at maturity from (from one hundred to one hundred and thirty on each valve), is synchronous with the formation of the rudimentary shell, while in the pauciplicate species here discussed they appear to be of secondary growth.

\section{DEVELOPMENTAL CHANGES}

General Form and Outline. In the growth of the shell a change becomes manifest in its outline and relative proportions. The young stages have the width greater than the length, but the more rapid axial growth of the shell reverses these proportions in maturity. Moreover in the incipient stages, the valves, as already noticed, are of nearly equal depth and con. 
vexity. In the next stage, the depth of the ventral valve has noticeably increased over that of the dorsal, and, as in the latter valve the median sinus has become distinctly developed, the difference in this respect becomes emphasized. The divergence of the valves in convexity becomes increased until maturity, and this growth is accompanied in the ventral valve by a correspondingly increasing incurvature of the beak.

Beaks. In the incipient shell, the beaks are erect and distant, but not prominent. By the development of the broad sinus on the dorsal valve, the beak of this valve becomes relatively less prominent and apparently more closely appressed to the cardinal line. On the opposite valve, every increase in convexity is accompanied by a corresponding increase in the incurvature of the beak, and as the shell approaches maturity, the incurvature becomes so great, that it has been necessary, in the drawings which are here given showing the features of the cardinal area, to represent the beak as broken away.

Foramen. The earliest stages of growth show a remarkable feature in the triangular, marginate, subequal fissures on the valves. This character may prove of a high taxonomic value, as it clearly indicates the relationship, in this respect, of Orthis to the Linguloids, and places the genus near the inarticulata. The foramen upon the ventral valve is, in every stage of development, open and free for the protrusion of the pedicle. Deltidial plates are absent in every stage of growth. In a secondary stage, a cardinal process begins to form in the apex of the dorsal foramen, soon widening and becoming tripartite. As age increases, this process is projected into the ventral foramen, never quite filling it, always leaving room for the protrusion of the pedicle. In immature conditions the cardinal process is attached to the shell only at the apex of the foramen, but with maturity it comes in contact with the sides of the foramen, and at this stage entirely fills the dorsal aperture. With the increasing incurvature of the ventral beak and cardinal area, the apertures of the two valves 
change their mutual angle, constantly lessening it as growth advances.

Plications. As noticed above, the earliest stages of growth observed show the strix to be already developed on the shell, five on the ventral and six on the dorsal valve. These plications are rapidly multiplied by interstitial addition, and in maturity number from one hundred to one hundred and thirty on each valve.

\section{Orthis hybrida, Sowerby, i 839}

Plate I, Figs. I3-18

$-\frac{\text { Hall. Twenty-eighth Ann. Rept. N. Y. State Mus. Nat. Hist., p. 149, pl. 21, figs. }}{\text { 18-25. I879. }}$
- Hall. Eleventh Ann. Rept. State Geol. Indiana, p. 285, pl. 21, figs. 18-25. 1882. Orthis hybrida passes through primary developmental stages which are essentially identical with those already described for $O$. elegantula. Sufficient has been said in that connection in regard to the similarity and probable identity of the earlier embryonic stages of the shell of both species, the origin of the entire specific difference which is so apparent in the later and mature periods of development lying in the unequal growth of the valves in convexity. This increase is relatively greater in the dorsal valve of $O$. hybrida than in that of $O$. elegantula, and less in the ventral valve of the former than in that of the latter species. Thus O. hybrida is a more discoid, lenticular shell, showing but slight evidence of a median fold and sinus and carrying on its surface at maturity just about as many plications or striæ as its associate.

There is an obese variation from the normal form of $\dot{0}$. hybrida, which was noticed by Professor HALL (loc. cit.), and this appears early in the development of the species, with a size of $3.5 \mathrm{~mm}$. in length and $4.5 \mathrm{~mm}$. in width, and reaches a maximum growth with dimensions of $\mathrm{I} 4 \times \mathrm{I} 3 \mathrm{~mm}$. This variation is due to internal thickening and increase in convexity, and is accompanied by abundant concentric growth-lines which are as 
rare in the normal form as in $O$. clegantula. Our representative series of this species affords variations between the following limits of size: $.5 \mathrm{~mm}$. length $\times .75 \mathrm{~mm}$. width (minimum), and $\mathrm{i} 7 \mathrm{~mm}$. length $\times 20 \mathrm{~mm}$. width (maximum).

\section{Strophomena RHoMboidalis, Wilckens, I 769 \\ Plate II, Figs. I-13}

- Hall. Twenty-eighth Ann. Rept. N. Y. State Mus. Nat. Hist., p. 151, pl. 22, figs.
4-10. I879.

This well known species, although extremely abundant in the mature state, is correspondingly rare in its undeveloped condition. The young specimens which have been found are nearly all more or less broken, and it is evident that while young, the shell was thin and delicate, consequently few of their remains have been preserved. The series which has been selected is, however, very complete in its representation of the distinct phases of growth through which the individuals pass in their development from youth to maturity. The initial form, without radiating striæ; the second phase, a shell radiatingly striate, without undulations; the third state, striated and concentrically undulated, but without the angular geniculation of the valves in front; and the last phase, with the full form and characters of maturity, offer a series of changes, not often traceable in Silurian brachiopods.

The development of the characters of the hinge-area is also very sat. isfactorily demonstrated and affords some interesting points of comparison with certain forms of Streptorhynchus and Strophonella. These features are noticed at the end of the description of the species. Strophonella striata.

SPECIFIC CHARACTERS

Mature Form (plate 2, figs. 4, 4a, 10, I3). Shell semi-elliptical or semicircular in outline. 
Dorsal valve flat or slightly concave in the upper part, with the marginal portions abruptly curved upwards in front; beak small, carrying on its inner side, a large, prominent, triangular callosity, grooved along its summit and nearly filling the area of the opposite valve.

Ventral valve usually convex in the upper part, becoming flat or concave below, and with the marginal portion produced and abruptly bent downwards, geniculating with the dorsal valve; beak small, usually perforated with a small circular foramen; hinge-line often $50 \mathrm{~mm}$. in length, equaling or greater than the width of the shell below; cardinal extremities twisted and often much extended; cardinal area narrow, edges parallel, formed by both valves; deltidial area of the ventral valve, broadly triangular, occupied by the grooved callosity under the dorsal beak.

Surface marked by regular, rounded, radiating striæ. From the beaks to the curtain, or geniculated portion, the shell is ornamented with regular, strong, concentric undulations or corrugations.

This species varies greatly in size and form, in the different horizons and localities where it is found. In many places the mature shells are about half the size of the specimens from Waldron.

Incipient Form (plate 2, figs. I, I $a, \mathrm{I} 1$ ).

The smallest entire specimen yet detected has a length of I. $25 \mathrm{~mm}$. The outline is semi-oval, with the greatest width near the middle, and about one-fourth greater than the length. Dorsal valve convex in the upper part, becoming concave toward the front. The hinge-area of this valve is very narrow and linear, and carries beneath the beak a small grooved callosity. Ventral value convex, sloping in all directions from near the foramen, around which the surface is slightly depressed. There is also a depression extending along the middle of the valve to the anterior margin. The place of the beak is occupied by an exsert, conical pedicle-tube, which partly protrudes beyond the cardinal margin of the valve and extends down to, and embraces the dorsal callosity. Cardinal area of the ventral valve comparatively broad, narrowing rapidly 
from the pedicle-tube to the extremities. Surface smooth, except along a narrow zone around the margin, which shows incipient radiating strix.

\section{DEVELOPMENTAL CHANGES}

The form of this species being somewhat complex, we may make a convenient subdivision of the development of the shell into four stages, which may be briefly characterized as follows :

Ist Stage. Length of shells .4-I mm.; surface smooth.

2d Stage. Length $1-2 \mathrm{~mm}$; shell radiatingly striated, without undulations. $3 d$ Stage. Length $2-20 \mathrm{~mm}$; shell radiatingly striated, and concentrically undulated.

4th Stage. Length $20-30 \mathrm{~mm}$, entire shell radiatingly striated, concentrically undulated in the upper part, abruptly produced and geniculated in front.

The changes taking place in the form and character of the shell from one stage to another can best be shown and used for comparison in the following tabulation, where the conditions incident to each stage of growth in the various parts of the shell are briefly described.

\section{Development of Strophomena rhomboidalis}

\begin{tabular}{|c|c|c|c|c|}
\hline & $\begin{array}{l}\text { Ist Stage. } \\
\text { Initial. }\end{array}$ & $\begin{array}{l}\text { ad Stage. } \\
\text { Infantile. }\end{array}$ & $\begin{array}{l}\text { 3d Stage. } \\
\text { Adolescent. }\end{array}$ & $\begin{array}{l}4^{\text {th Stage. }} \\
\text { Mature. }\end{array}$ \\
\hline Size.......... & $\begin{array}{l}.4 \mathrm{~mm} .-\mathrm{mm} \text {. in } \\
\text { length, } 4 \mathrm{~mm} .- \\
\text { 1.5 mm. in width. }\end{array}$ & $\begin{array}{l}\text { I mm. }-2 \mathrm{~mm} \text {. in } \\
\text { length, } 1.5 \mathrm{~mm} .- \\
2.5 \mathrm{~mm} \text {. ill width. }\end{array}$ & $\begin{array}{l}2 \mathrm{~mm} .-20 \mathrm{~mm} \text {. in } \\
\text { length, } 2.5 \mathrm{~mm} .- \\
40 \mathrm{~mm} \text {. in width. }\end{array}$ & $\begin{array}{l}20 \mathrm{~mm} .-30 \mathrm{~mm} \text {. in } \\
\text { length, } 40 \mathrm{~mm} .- \\
50 \mathrm{~mm} \text {. in width. }\end{array}$ \\
\hline Form........... & $\begin{array}{l}\text { Transversely semi- } \\
\text { oval; cardinal ex- } \\
\text { tremitiesobtusely } \\
\text { angular. }\end{array}$ & $\begin{array}{l}\text { Transversely semi- } \\
\text { elliptical ; cardi- } \\
\text { nal extremities } \\
\text { angular. }\end{array}$ & $\begin{array}{l}\text { Longitudinally } \\
\text { semi-elliptical; } \\
\text { cardinal extremi- } \\
\text { ties angular, be- } \\
\text { comingproduced, } \\
\text { not twisted. }\end{array}$ & $\begin{array}{l}\text { Longitudinally } \\
\text { semi-elliptical; } \\
\text { cardinal extremi- } \\
\text { ties acutely angu- } \\
\text { lar, extended and } \\
\text { twisted. }\end{array}$ \\
\hline
\end{tabular}


Development of Strophomena rhomboidalis - Continued

\begin{tabular}{|c|c|c|c|c|}
\hline & $\begin{array}{l}\text { rst Stage. } \\
\text { Initial. }\end{array}$ & $\begin{array}{l}\text { ed Stage. } \\
\text { Infantile. }\end{array}$ & $\begin{array}{c}\text { 3d Stage. } \\
\text { Adolescent. }\end{array}$ & $\begin{array}{l}4^{\text {th }} \text { Stage. } \\
\text { Mature. }\end{array}$ \\
\hline Contour .. & Convex. & Depressed convex. & $\begin{array}{l}\text { Very slightly con- } \\
\text { vex. }\end{array}$ & $\begin{array}{l}\text { Geniculate, making } \\
\text { the shell highly } \\
\text { arched longitudi- } \\
\text { nally. }\end{array}$ \\
\hline Dorsal valve.... & $\begin{array}{l}\text { Convex, concave } \\
\text { on the margin; } \\
\text { umbo prominent. }\end{array}$ & $\begin{array}{l}\text { Concave, except on } \\
\text { the umbo. }\end{array}$ & $\begin{array}{l}\text { Concave, except on } \\
\text { the umbo. }\end{array}$ & $\begin{array}{l}\text { Flat or concave on } \\
\text { the body of the } \\
\text { she } 11 \text {; abruptly } \\
\text { produced and } \\
\text { curved upwards } \\
\text { around the mar- } \\
\text { gins. }\end{array}$ \\
\hline Ventral valve... & Convex. & $\begin{array}{l}\text { Convex, semi-coni- } \\
\text { cal with the beak } \\
\text { at the apex. }\end{array}$ & $\begin{array}{l}\text { Convex in the up- } \\
\text { per part, flat or } \\
\text { concave on the } \\
\text { margin. }\end{array}$ & $\begin{array}{l}\text { Convex in the up- } \\
\text { per part, flat or } \\
\text { concave in the } \\
\text { middle, and ab- } \\
\text { ruptly bent down- } \\
\text { wards below. }\end{array}$ \\
\hline Surface......... & Smooth. & Radiatingly striate. & $\begin{array}{l}\text { Radiatingly striate } \\
\text { and concentri- } \\
\text { cally undulate. }\end{array}$ & $\begin{array}{l}\text { Entire surface, } \\
\text { radiatingly stri- } \\
\text { ate, concentrical- } \\
\text { ly undulate in the } \\
\text { upper part only. }\end{array}$ \\
\hline Cardinal area... & $\begin{array}{l}\text { Ventral high ; dor- } \\
\text { sal very slender. }\end{array}$ & $\begin{array}{l}\text { Ventral high; dor- } \\
\text { sal very slender. }\end{array}$ & $\begin{array}{l}\text { Ventral narrow } \\
\text { dorsal narrow. }\end{array}$ & $\begin{array}{l}\text { Both narrow, sub- } \\
\text { eqtal. }\end{array}$ \\
\hline Pedicle-tube.... & $\begin{array}{l}\text { Exsert, full height } \\
\text { of the area. }\end{array}$ & $\begin{array}{l}\text { Not exsert, full } \\
\text { height of the area. }\end{array}$ & $\begin{array}{l}\text { Nearly full height } \\
\text { of the area. }\end{array}$ & $\begin{array}{l}\text { Obsolescent or ob- } \\
\text { solete. }\end{array}$ \\
\hline Foramen.... .. & $\begin{array}{l}\text { Present, circular, } \\
\text { elevated. }\end{array}$ & Present, circular. & Present, circular. & Usually present. \\
\hline Dorsal callosity. & Snuall, grooved. & Small, grooved. & Larger, grooved. & $\begin{array}{l}\text { Very large and } \\
\text { deeply grooved. }\end{array}$ \\
\hline
\end{tabular}


Among the mature shells, the greatest variation is to be found in the development of the anterior curtain, or geniculate and sloping marginal area of the valves. In some specimens this is so excessively developed, that the posterior, or concentrically undulated portion of the ventral valve is at right angles to the plane of the margin. Also, in many specimens the curtain is obscurely plicate, and the radiating strix are often irregular and sometimes fasciculate, while on the upper part of the valves these strix are very uniform in their arrangement. No specimens have been noticed which are so strongly quadriplicate as those illustrated by Mr. DAvidson, on plate 39 of the "British Silurian Brachiopoda."

Senile specimens usually have the valves very much thickened from internal growth, and the margins show strong varices. It is noticeable that nearly all the old shells are covered with a growth of cranias, bryozoa, favosites, etc., and it is very difficult to free the shell from this overgrowth. In consequence of this, many of the shells are scarcely recognizable, and resemble agglomerations of bryozoa and corals. The only other species of brachiopoda at this locality commonly thus overgrown and involved, is Atrypa reticularis.

Strophomena rhomboidalis is cosmopolitan and has been discussed by many authors who have shown its great variation and wide distribution. So far as known, the youngest specimen heretofore figured is one represented by Mr. DAvidson.*. This is an individual belonging to the third stage of development, having a length of nearly $6 \mathrm{~mm}$. and a distinct circular perforation of the beak.

* British Fossil Brachiopoda, Vol. III, Devonian and Silurian, pp. 283, 284, pl. 30, fig. 6.

The same. General Summary to the British Fossil Brachiopoda, p. 289. 


\author{
Streptoriy ynchus subplanum, Conrad, I 842 \\ Plate II, Figs. I4-20
}
- _ - Hall. Twenty-eighth Ann. Rept. N. Y. State Mus. Nat. Hist., p. 15I, pl. 21, figs. 26-33. 1879.
——, Hall. Eleventh Ann. Rept. State Geol. Indiana, p. 288, pl. 21, figs. 26-33. 1882.

The series selected to represent the development of this species comprises fourteen specimens ranging from $1.5 \mathrm{~mm}$. to $26.5 \mathrm{~mm}$. in length. The external features of form and surface ornaments are remarkably constant from the young to the mature shells. There is, however, a slight progressive modification in the relative convexity of the valves. The dorsal valve of young and half-grown individuals is nearly flat, while the ventral is moderately convex. In old specimens both valves are convex, with the dorsal somewhat more so than the ventral. The most marked changes due to advancing growth are those which take place in the hinge. Some men. tion of these is made under the description of Strophonella striata, where it is stated that the pedicle-tube retains its embryonic form and size nearly up to maturity, after which it is obscured by the internal thickening of the shell ; also, that the callosity under the beak of the dorsal valve uniformly increases in size from the youngest forms to full-grown specimens.

\title{
SPECIFIC CHARACTERS
}

Mature Form (plate 2, figs. I 5, I $5 \alpha$, I 7,20 ). Shell semicircular or semi-elliptical, depressed convex; hinge-line longer than the width of the shell; cardinal angles flat and extended.

Dorsal valve moderately and uniformly convex except at the cardinal angles; umbo not defined; beak small.

Ventral valve convex on the umbo, less convex below, and in many specimens the marginal portion is flat or slightly concave; beak small, somewhat arched. Hinge-area nearly equal in both valves, usually appearing as a deep angular groove along the cardinal margin. Under the beak of the dorsal valve is a large triangular callosity, grooved on the inside, 
and nearly filling the fissure of the opposite valve. Deltidium of the ventral valve broadly triangular, extending to just below the beak, and margined on each side by two narrow areas in the form of scalene triangles, which may represent the deltidial plates of other genera. Beak imperforate.

Surface marked by from fifty to one hundred (according to the size of the shell) regular, rounded striæ, with equal interspaces, increasing in number by interstitial additions. The entire shell is also ornamented with very fine, regular, sharp, concentric strix. A large spectmen has a length of $26 \mathrm{~mm}$., and the width, measured along the-hinge-line, is about $38 \mathrm{~mm}$.

Incipient Form (plate 2, figs. 14, 14a). The smallest specimen measures $1.5 \mathrm{~mm}$. in length, by $2.3 \mathrm{~mm}$. in width along the hinge-line. The outline is semielliptical, with the cardinal angles slightly extended. Dorsal valve concave in the upper part, and slightly convex below. Ventral valve convex; beak prominent, projecting beyond the hinge-line.

The hinge characters are not well preserved in this individual. The first specimen in the ascending series which shows the hinge distinctly, has a length of $2.25 \mathrm{~mm}$., and will be described in the development of this part.

The surface of the incipient shell is marked by seventeen alternating, narrow, elevated radiating lines, with wider interspaces, and also shows sev. eral lines of growth near the margin.

\section{DEVELOPMENTAL VARIATIONS}

No marked changes occur in the general form of the shell, other than the gradual inçrease in the convexity of the dorsal valve and in the extension of the cardinal angles. The dorsal valve is usually quite flat in specimens having a length of $10 \mathrm{~mm}$. or less. The radiating lines increase in number by interstitial additions, from the youngest form to maturity, and the fine concentric strix appear on all the specimens, including the initial individual in the series, where they are developed around the margins of the valves.

The earliest phase of the hinge yet noticed, is found in a specimen 
having a length of $2.25 \mathrm{~mm}$. The dorsal valve shows a foramen in the cardinal area under the beak, margined by a slight thickening of the shell. The ventral valve preserves a small perforate pedicle-tube at the apex, extending about two-thirds of the distance down to the hinge, below which is a triangular deltidial opening of the same width as the dorsal foramen.

A specimen $4 \mathrm{~mm}$. in length (plate 2, fig. 19), shows a more advanced development of the same parts. The dorsal callosity has nearly filled the sinus under the beak and has a narrow groove in the center. The fissure of the ventral valve has increased considerably in size and relative height, showing narrow marginal plates, or defined areas which may be deltidial plates. The pedicle-tube is still perforate, but has not increased in size beyond the initial stage.

From this point to maturity, the hinge increases in width, the dorsal callosity grows rapidly and nearly fills the fissure of the opposite valve. The pedicle-tube is obscured and the perforation obsolete. The deltidial plates, or lateral areas, are clearly defined, and have the form of narrow scalene triangles.

No important variations have been noticed among the mature specimens. Occasionally an individual diverges from the normal form by having mucronate cardinal angles, or a senile specimen shows strong imbricating varices of growth, but, as a whole, the form and surface ornaments in this species are very uniform.

$$
\begin{aligned}
& \text { Strophonella striata, Hall, I } 843 \\
& \text { Plate III, Figs. i-8 }
\end{aligned}
$$

Strophodonta striata, Hall. Twenty-eighth Ann. Rept. N. Y. State Mus. Nat. Hist., p. 152, pl. 23, figs. 1-6. 1879 .

—_, Hall. Eleventh Ann. Rept. State Geol. Indiana, p. 290, pl. 23, figs. 1-6. 1882.

The present form is one of the most delicate and fragile species of brachiopoda at Waldron. Individuals are not of rare occurrence, but the majority of them are more or less broken. The upper portion of the shell, 
or that along the hinge, being thicker and stronger than the remainder, is more often preserved, and the series is only complete in the representation of this portion, although there are several small specimens which are sufficiently entire to show the early form of the shell.

As in the other species which, in their mature proportions, depart from the type of structure in the group, the incipient shell is found to revert to the primitive form. The full-grown examples of this species are concavoconvex, the concave valve being the ventral, while in the young, the ventral valve is the more convex. This change in the relative convexity of the valves does not begin until the individuals are about half-grown, and is produced by the gradual deflection of the margin with the increase in the size of the shell.

The developinent of the features of the hinge is very characteristic, and, as in the other strophomenoid forms, is of primary interest. Both the dorsal callosity and pedicle-tube continue to increase in size with the growth of the shell, from the incipient form to maturity.

\section{SPECIFIC CHARACTERS}

Mature Form (plate 3, figs. 2, 2a, 8). Shell semi-elliptical, wider than long, the greatest length being along the hinge. The body cavity is very shallow, and the shell has a concavo-convex form.

Dorsal valve flat in the upper part, moderately convex in front. $V c n$ tral valve slightly convex on the umbo, and concave over the remainder of the valve. Hinge-area formed by both valves. Ventral area the wider, carrying in the center a small conical pedicle-sheath which is usually minutely perforate at the apex. Dorsal area linear, with a callosity in the middle, under the pedicle-tube of the opposite valve.

Test thin, surface ornamented by about fifty alternating radii, with three or four fine filiform stria in each interspace; also crossed by fine irregular strix of growth. 
Two specimens measure respectively, $19.5 \mathrm{~mm}$. and $14 \mathrm{~mm}$. in length, and $23 \mathrm{~mm}$. and $16 \mathrm{~mm}$. in width, at the hinge.

Incipient Shell (plate 3, figs. I, I $a, 3$ ). The form is nearly planoconvex. Dorsal valve convex on the umbo, flat below. Ventral valve moderately convex, with a prominent pointed beak. Hinge narrow, with a small cylindrical perforated pedicle-tube in the center of the ventral area, and a small callosity in the dorsal area. In the smallest specimen observed, the surface is marked by eleven radii on the ventral valve, but is otherwise apparrently smooth. Length $2.25 \mathrm{~mm}$; width in the center, $3 \mathrm{~mm}$.

\section{DEVELOPMENTAL CHANGES}

On account of the imperfection of the material, it is impossible to trace any minor changes in the outline of the valves, and the specimens indicate that no considerable transformation took place. The modifications in the convexity of the valves is of more importance in this species, and can be readily observed. In the young individuals, up to about one-third full size, the ventral valve is slightly convex and the dorsal valve nearly flat. Further growth of the shell changes these relations, by the gradual deflection of the margin, until the general form of the ventral valve is concave and the dorsal valve is convex.

The radii appear very early in the growth of the shell, the smallest individual having eleven on the ventral valve, the majority of which extend to the umbo. They probably first appeared in pairs and are found to increase in number afterward by simple intercalation.

The hinge-area is developed upon both valves in all stages of growth, although in the early stages the cardinal area of the dorsal valve is very narrow, but gradually increases, until at maturity, it is nearly equal to the area of the ventral valve.

The pedicle-tube is at first cylindrical and short. Advancing in the series, it is found to become conical from growth, and from the widening of the fissure, until, in full grown specimens, it is wider than high. A careful 
examination reveals the perforation in all stages of the development of the shell. It is, however, very minute, and it is not probable that the extremely small peduncle could have performed its full function. Indeed, it may be surmised that in none of the three strophomenoid species here described was the fleshy arm sufficiently strong in mature individuals to serve as a secure support to the shell. In the embryonic forms it was a more important organ.

The hinge of the young shell illustrated in figure 4, plate 3 , shows an excessively elongate, cylindrical pedicle-tube, of which more than onehalf the length is projected above the beak. It must be considered as a supra-calcification about the peduncle, and apparently indicates a more complete functional extension.

The grooved dorsal callosity appears in the beginning of the series, and gradually increases in size, and detrudes so that the groove shows on the exterior, but just before maturity it is either filled, or introverted into the deltidial cavity.

The FEATURES of the hinge, fissure and callosity, in the Strophomenidx, and their embryological development, seem to be peculiar to the group. They are of special interest both on this account, and also because the family has no living congeners. Although the separate characters have been presented in detail in each of the preceding descriptions, a brief review of the hinge characters is here given, showing more clearly their intimate relationships.

In the three species, Strophomena rhomboidalis, Strophonella striata and Streptorhynchus subplanum, the initial form of the hinge is the same. Each shows a slender callosity under the beak of the dorsal valve, and a perforate pedicle-sheath in the ventral valve, which does not entirely close the deltidial opening. From this initial stage, development proceeds in a different manner for each of the three species. Strophomena rhomboidalis and Strophonella striata develop in a parallel series until the individuals are 
about one-third grown in the first species, and two-thirds full size in the second. That is, the dorsal callosity and pedicle-sheath each increase uniformly in size up to these periods. Beyond this the divergence is rapid and marked. In Strophomena rhomboidalis, the grooved callosity increases in size, so as to nearly fill the broad fissure in the ventral valve, while the pedicle-sheath ceases growth, is atrophied and lost, although, in many cases, the perforation persists. Strophonella striata continues its hinge development without a change, except that, at full maturity, the groove on the-callosity becomes introverted into the pedicle-sheath.

The third mode of development is exhibited by Streptorhynchus subplanum, in which the pedicle-sheath does not increase beyond its initial size, while the dorsal callosity develops up to the maturity of the shell, and, as in Strophonella striata, the groove is on the inner side.

The function of this groove in the callosity of the dorsal valve in the strophomenoids has not been satisfactorily determined, its existence having sometimes been considered as evidence of the perforation of this valve.* In all young shells, it is evident that the passage of the pedicle is not through this groove in the dorsal callosity, but through the apex of the ventral valve by means of the channel which has been here termed the pedicle-tube or sheath. In growth-stages where there can be no question of the functional activity of this sheath, the dorsal callosity is already grooved or sinuate. It might be surmised that the purpose of the groove was to avoid compressing the pedicle when the valves were open, and this it may have been to some extent; but the evidence furnished by both recent and fossil species indicates that the valves of the articulate brachiopods could be opened only a very slight degree. The groove persists in species after the true pedicle-perforation in the ventral valve is closed and functionally useless. Its origin appears to be due to the organic deposition about the bases of the two interior cardinal processes, the interstitial area of slower deposition being represented by a fissure, groove or sinus. 


\section{Streptis waldronensis, Miller and Dyer, i 878 \\ Plate III, Figs. 9, Io}

Spirifera? zualdronensis, Miller and Dyer. Contributions to Palæontology, Jour. Cinti. Soc. Nat. Hist., April, 1878.

Triplesia putillus, Hall. Trans. Alb. Inst., vol. x, Abstract, p. 16. 1879.

— - Hall. Eleventh Ann. Rept. State Gèol. Indiana, p. 298, pl. 27, figs. 19-22. 1882.

This species is among the rarest of the Waldron brachiopoda and it is impossible to present a series representing the variety and progress of development, as in some of the more common forms. There were but two specimens, both adults, discovered in the State Collection at the time of the publication of the "Descriptions of New Species of Fossils from the Niagara Formation at Waldron, Indiana." * Fortunately, we have more recently detected a young individual of about one-fourth the normal adult size, which offers some interesting details in its form and characters.

The asymmetry of the shell is manifest even at this early stage of growth (although the median fold is not developed), and is evinced by the position of the beak of the ventral valve, and by the contour of the margins. It is probable that in a still earlier phase of growth, the two valves are symmetrical, or nearly so.

In the young individual under consideration (plate 3 , figs. $9,9^{a}, 9^{b}$ ), the outline is nearly circular. The beak of the ventral valve is very much elevated, projects beyond the cardinal line and is directed toward the left side of the shell. The apex is truncated, and the opening is confluent with the area below.

The cardinal area is high, forming a large triangular fissure which is apparently not closed by deltidial plates. The beak of the dorsal valve is depressed, and limited by a slight furrow on each side. No lines of growth are visible, but the surface is somewhat granulose, as in many small shells of other species.

\footnotetext{
* James Hall. Read before the Albany Institute, March 18, 1879.
} 
The principal differences to be noted in comparison with the adult individuals are the subcircular outline of the shell, the depressed valves, the absence of a median fold, and the large deltidial area.

Eichimaldia Reticulata, Hall, 1868

Plate. III, Figs. II-I3

—_ Hall. Twenty-eighth Ann. Rept. N. Y. State Mus. Nat. Hist., p. 169, pl. 26, figs. 50-54. 1879.

_- - Hall. Eleventh Ann. Rept. State Geol. Indiana, p. 312, pl. 26, figs. 50-54. 1882.

Very few of the earlier growth stages of this species have been observed and these show but comparatively little variation from the features of the normal adult. On plate 3 is given a figure of the youngest example found, which has a length and width of $3 \mathrm{~mm}$., while the usual adult is about $16 \times 16 \mathrm{~mm}$., varying in relative proportions with the increase of senile obesity. The change in outline during growth is from subcircular to subtriangular, and in earlier stages, the ventral fold and sinus are very ill-defined. The peculiar triangular exfoliation of the shell on the umbo of the ventral valve is evidently a constant feature in every stage of growth after the shell becomes attached. The nature of this peculiarity was indicated by BILLINGS in the original diagnosis of the genus (Ann. Rept. Canadian Geol. Survey, I $857-58$ ), and was demonstrated more fully by Professor HalL, in the Twentieth Report on the Condition of the New York State Cabinet of Natural History (pp. 274-278, 1867). This area is underlaid by an internal shelf or diaphragm attached along its lateral margins, and having fully, or rather more than, the width of the median sinus. Through the space thus left between the shell and the internal diaphragm, communication is afforded with the outside world. Mr. JoHn Young has called attention to the fact that in E. capcwelli, the margins of the external reticulated layer of the shell about the umbonal bare spot, are rough and ragged, the superficial hexagonal cells being without finish along these edges, suggesting therefrom, that the animal was attached to marine 
objects by the substance of the shell, and afterward broken away from its attachment. (See Davinson, General Summary, pp. 355, 356.) It is true that the anterior edge of this area may be rough and uneven, but the lateral edges appear invariably straight and diverge at an essentially constant angle. The latter represent the lines of attachment of the internal plate to the interior of the valve, and if the shell has been broken in detachment from foreign bodies, the fracture in these directions has been guided by these lines, but on the unsupported anterior margin it has been rough and irregular. Upon the hinge-line of the ventral valve, there exists no aperture for the protrusion of the pedicle; by the peculiar development of the articulating processes of both valves, the entire cardinal margin is closed, and therefore the passage between the internal plate and the surface of the valve may have been for the use of this organ; or, it may be suggested, that as this space is rather too narrow and explanate for such a purpose, Eichwaldia may have been attached by the substance of the shell, the internal shelf acting as a support to the strain upon the umbo, and a protection to the animal in case the shell were broken from its attachment.

\section{Anastrophia internascens, Hall, i879}

Plate III, Figs. 14-16

- - Hall. Twenty-eighth Ann. Rept. N. Y. State Mus. Nat. Hist., p. 168, pl. 26, figs. 4149. 1879.

_- Hall. Eleventh Ann. Rept. State Geol. Indiana, p. 3Ir, pl. 26, figs. 41-49. 1882.

In tracing the development of this species, the principal feature to be noticed is that the elemental shell conforms with the type of an ordinary brachiopod, such as Rhynchonella, that is, the dorsal valve, although somewhat the more convex, is smaller than the opposite valve, while in the mature state the dorsal valve is considerably larger and projects beyond the beak of the ventral valve. It is the development of this 
character which constitutes the most conspicuous change in the shell in its growth from the young to the fully mature condition.

\section{SPECIFIC CHARACTERS}

Mature Form (plate 3, figs. 15, 16, 16a).

Shell ventricose. Outline transversely subelliptical, sometimes nearly as long as wide.

Ventral valve convex, depressed in front, forming a more or less defined sinus which carries four or five of the plications; beak short, acute; area short, broadly triangular, usually not exposed.

Dorsal valve gibbous, with the central portion elevated, frequently presenting a broad undefined median fold ; beak incurved under the beak of the opposite valve; umbo prominent.

Surface marked by about fifteen strong, simple, elevated, rounded or angular plications on the body of the shell, and smaller bifurcating plications on the latera. Occasionally intercalated plications are present on the middle of the valves. The plications are crossed by fine arching striæ of growth, which are sometimes aggregated, forming conspicuous concentric lines or varices of growth.

Mature shells measure from I I to $17 \mathrm{~mm}$. in length, and from $\mathrm{I} 2$ to 19 $\mathrm{mm}$. in width. The depth of the conjoined valves varies from 9 to $12 \mathrm{~mm}$.

Incipient Form (plate 3, figs. 14, 14a). The smallest shell observed has a length of $2 \mathrm{~mm}$. and a width of $2.25 \mathrm{~mm}$. The dorsal valve is slightly more convex than the ventral and is a little shorter. Eight rounded plications are shown, five of which extend to the umbo of the valve. A short plication is intercalated in the middle and there is also a short one on each side of the valve. Ventral beak small and elevated, with a broad, triangular, open area below.

\section{DEVELOPMENTAL CHANGES}

The series of specimens selected to represent the development of this species contains fifteen normal individuals, varying from a length of $2 \mathrm{~mm}$. to a length of $\mathrm{I} 7 \mathrm{~mm}$. The proportions of length and width remain nearly constant throughout, the width being somewhat the greater. 
In the smallest specimen, the depth of both valves is less than one-half the length of the shell. This relation gradually changes as the shell becomes larger and more convex, until, in mature individuals, the depth is equal to three-fourths or four-fifths the length of the shell, and in extremely obese specimens this ratio is often exceeded.

The dorsal valve is more convex than the opposite valve, in all the stages of growth which have been observed, although in the elemental shell, the difference is scarcely perceptible, while in the mature form it is a conspicuous feature. This valve is also shorter than the ventral in specimens up to a length of about $7 \mathrm{~mm}$. From 7 to $12 \mathrm{~mm}$., both valves are of nearly equal length. Further growth causes the umbo of the dorsal valve to protrude beyond the beak of the opposite valve, and the beak is incurved and penetrates the area. It seems evident that if we had the true initial shell, the dorsal valve would be found not only smaller but less convex than the opposite valve.

The fold begins to be apparent in individuals having a length of about Io $\mathrm{mm}$., and is expressed by the arching of the anterior margin. It does not sufficiently develop to become a characteristic feature and is more or less undefined, even in many full-grown specimens.

The plications increase both by bifurcation and interstitial addition. The smallest number observed is eight, and this is gradually increased with the growth of the shell, until there are about fifteen principal plications on the body of the shell, and several smaller ones just below the cardinal extremities. The concentric strix are not often preserved and the plications therefore form the only conspicuous character of the surface ornamentation.

The deltidial plates reach but a slight development, the triangular opening becoming completely filled by the incurved beak of the dorsal valve. 
Rhynchonella acinus, Hall, 1863

Plate IV, Figs. 9-I I

—_ Hall. Twenty-eighth Ann. Rept. N. Y. State Mus. Nat. Hist., p. 306, pl. 26, figs. 7-1 I. 1879.

_- Hall. Eleventh Ann. Rept. State Geol. Indiana, p. 306, pl. 26, figs. 7-II. I882.

Were Rhynchonclla acinus a rare species, it might readily be confounded with the variety of $R$. indiancnsis, which bears but a single plication in the ventral sinus. It appears, however, to have been very prolific, and its abundance serves to emphasize its specific independence. The liability to confuse it with any of the associated species arises only among forms of immature growth. Beginning with a shell which is apparently in the actual initial stage, measuring $1.2 \times .8 \mathrm{~mm}$., our series is very evenly consecutive up to maturity, when the average dimensions are $8 \times 6 \mathrm{~mm}$.

\section{SPECIFIC CHARACTERS}

Mature Form (plate 4, figs. II-I $b$ ). Shell small, longitudinally ovate, subattenuate toward the beak, and truncate in front. Cardinal margins long and rapidly sloping, extending more than half-way across the shell; sides flattened, slightly excavate. Valves subequally convex.

Ventral walve full and rotund on the umbonal region, flattened at about the middle, thenceforward sinuate; beak incurved, but not procumbent ; foramen generally concealed, or when slightly exposed, elongate or subtriangular.

Dorsal valve more flattened in the umbonal region and in the middle, whence a low fold proceeds to the margin.

Surface marked by low rounded plications. The ventral sinus bears a single plication which is generally faint, often nearly obsolete. On each side of the sinus are four plications, those abutting on the cardinal margins being indistinct. On the dorsal valve, the low, flattened fold bears two plications which are the strongest upon the shell; these are accompanied by three plications on each latus, making the whole number on this 
valve eight. No concentric growth-lines are apparent. Average dimensions $8 \times 6 \mathrm{~mm}$.

Variations from the normal adult.

Two plications sometimes occur in the sinus, and in such cases they are each stronger than the single sinal plication in the normal adult. The addition of the plication to the sinus increases the number in the fold to three, and the total number of plications on the shell by two.

Initial shell (Compare plate 4 , figs. $9,9 a, 9 b$.) Two individuals, one measuring $1.2 \times 8 \mathrm{~mm}$., the other $1.4 \times 9 \mathrm{~mm}$, apparently indicate the initial stages in the growth of this shell. Neither of these examples has served well for illustration, on account of the lack of well-defined details, but they may be described as follows:-Attenuate, subspatulate. Ventral valve with erect, straight beak; cardinal area high, convex, with a prominent dorsum. Dorsal valve flattened or slightly sinuate. Features of the cardinal area not discernible; from analogy, the foramen would be triangular and unobstructed. In figures $9-9 b$, which show a secondary stage of growth in the shell, the portion included within the first growth-line will represent very well the characters of the primitive shell.

\section{GENERAL DEVELOPMENTAL CHARACTERS}

The gradual incurvature of the beak and consequent concealment of the ventral foramen may be assumed from the foregoing. It harmonizes with the associated species of the same genus in the slight variation in the form and proportions of the foramen in consecutive stages of growth, as well as in the reversal of the embryonic fold and sinus to the mature sinus and fold. The plications of the latera seem to appear simultaneously after the first varix, as shown in the figures referred to, and their number does not change materially until maturity. The embyronic sulcus on the dorsal valve, correlate with the ventral dorsum in the primitive stage, is continued at maturity into the median sulcus separating the two plications of the dorsal fold. 
Rhynchonella neglecta, Hall, i 852

Plate IV, Figs. 3, 6-8

- Hall. Twenty-eighth Ann. Rept. N. Y. State Mus. Nat. Hist., p. I62, pl. 26 , figs. I-6.
I879.
- Hall. Eleventh Ann. Rept. State Geol. Indiana, p. 305, pl. 26, figs. I-6; pl. 27 , fig.
For a species so abundant as this in the Waldron fauna, the diagnostic features are retained with unusual persistence within very narrow limitations. Unlike its associate, $R$. indianensis, which it almost equals in numerical representation, there are no well-established and perduring variations from the normal adult form, and our observations are therefore limited to an essentially unvarying phase.

\section{SPECIFIC CHARACTERS}

Mature Form (plate 4, figs. 8, 8a). Shell small, transversely subovate; umbo scarcely prominent. Cardinal slopes long and flattened, rounding to the anterior margin which is nearly straight.

Ventral valve with the umbo elevated and slightly incurved at the tip, overhanging an elongate subtriangular foramen. Umbonal region slightly convex, the convexity extending for one-third the length of the shell ; thence forward the shell is rapidly depressed medially to form a deep sinus, which makes a high quadrangular extension on the margin; lateral portions depressed.

Dorsal valve with the umbo low and inconspicuous; apex concealed within the foramen of the opposite valve. The shell becomes rapidly elevated medially to form the fold, the latera being full and convex.

Surface covered with regular, sharp and prominent plications, which do not vary in number at normal maturity, and which, in the growth of the shell, are increased only from the cardinal margins. Of these plications, the fold bears four, the sinus, therefore, three, and each of the latera, five, those nearest the cardinal margins being obscure. This makes in all for the 
ventral valve, thirteen, and for the dorsal, fourteen plications. Dimensions of an average example, length, width and depth, 9,8 and $5 \mathrm{~mm}$.

A single individual presents the only important abnormality noticed, viz.: a failure to produce the requisite plications upon the latera, the dorsal valve bearing but five, and the ventral, six. Of these, three are on the fold, two in the sinus. It is interesting to notice that in the umbonal region the normal number of plications had been formed in their regular arrangement; their disappearance on the latera and irregular disposition in fold and sinus took place abruptly upon the completion of a growth-line $2 \mathrm{~mm}$. from the apex. This is a marked instance of reversion after the assumption of certain adult features.

Incipient Form (plate 4, figs. 6, 6a). The example with which our series opens measures $.75 \times .5 \mathrm{~mm}$. It is elongate subtriangular, with the ventral beak elevated and erect, the cardinal margins sloping for twothirds the length of the shell; foramen triangular, slightly, if at all, encroaching upon the apex, without deltidial plates, margins thin; dorsal beak rounded, inconspicuous. At one-third the distance from the apex to the anterior margin, fine thread-like plications appear, four upon the dorsal, and three (five?) upon the ventral valve. The median sulcus on the dorsal valve is broader and deeper than any other, forming the embryonal sinus, and is accompanied by a correlatively strong plication on the opposite shell.

\section{DEVELOPMENTAL VARIATIONS}

General Form and Outline. The form of the shell varies from dimensions in which the length is one-quarter greater than the width, to those of maturity when the width is slightly greater than the length. The depressed, subspatulate embryo eventually becomes convex and deep. The embryonal sinus and fold on the dorsal and ventral valves respectively, are never so prominent as in $R$. indianensis, and soon become lost, the 
former in a sulcus, and the latter in one or more sulci upon the reversed fold and sinus of maturity.

Beak and Foramen. The erect and acute beak of the elementary stages of growth, becomes, at maturity, but slightly incurved, and never procumbent on the dorsal umbo. The foramen, at the outset triangular, subsequently has its margins thickened, and develops small and obscure deltidial plates at its base, which at maturity leave the foramen elon. gate and not circular. In respect to these features, the development of the species is identical with that of $R$. indianensis.

Plications. In the first observed stadium, only the umbonal area is smooth, and from the analogy of $R$. indianensis, it would appear that the initial growth-stage yet fails us. At a size of $2.5 \times 2 \mathrm{~mm}$., the number of plications has increased from four to ten on the dorsal, and from three (five?) to eleven on the ventral valve, and this, added to a pair of extremely obscure plications near the cardinal margins, is the normal number for maturity.

\section{RhynChONELIA Whitil, Hall, I 863 \\ Plate IV, Figs. I, 2, 4, 5}

- Hall. Twenty-eighth Ann. Rept. N. Y. State Mus. Nat. Hist., p. 164, pl. 26, figs. 23-33.
1879.
- Hall. Eleventh Ann. Rept. State Geol. Indiana, p. 307, pl. 26, figs. 23-33. I882.

Like Rhy'nchonella neglecta, this species is subject to very slight variations at maturity, and its specific expression is well marked, but a certain embarrassment attends the first endeavor to separate the immature individuals from those of allied species. This, however, disappears with a careful eye properly estimating the essential characters of the species. The earliest stage of growth we have found measures $2.75 \mathrm{~mm}$. in length by $2 \mathrm{~mm}$. in breadth, and from this size upward to that of $13 \times 13 \mathrm{~mm}$. all variations are present. 
Mature Form (plate 4, figs. 2, 2a, 2b). Shell transversely subelliptical; length and width about equal.

Ventral valve shallow; beak high, acute, somewhat attenuate, with the apex slightly incurved, but not concealing the triangular unclosed foramen which reaches entirely across the cardinal area. At its apex the foramen encroaches slightly upon the umbo, and is narrowed somewhat toward the base by the imperfectly developed deltidial plates. A median depression makes its appearance at about one-third the distance from the umbo to the anterior margin, and soon develops into a deep sinus with sharply sloping sides.

Dorsal value deeper and more gibbous; beak inconspicuous, and incurved beneath the ventral foramen. A strong median fold corresponds in development with the median sinus of the opposite valve.

Surface marked by strong, simple, subangular plications, invariably two upon the fold and one in the sinus, with six on each of the latera, making thirteen on the ventral, and fourteen on the dorsal valve. Of these, the plications near the cardinal margin are low and incipient, but the full number becomes permanent early in the history of the individual. Faint concentric growth-lines are sometimes visible. Dimensions of average adult I I $\times$ I I $\mathrm{mm}$.

Abnormalities at maturity. The variations from the normal mature form are, as far as observed, wholly due to continued internal growth after individual maturity has been attained, and this is to be regarded as the concomitant evidence of senescence. There may be either a marginal thickcning, which gives the shell a truncate appearance, or a general internal thickcning, making the shell unusually gibbous, and forcing the ventral beak over upon the dorsal umbo.

Incipient Form (plate 4, figs. I, I $a$ ). The youngest individual observed measures $2.75 \times 2 \mathrm{~mm}$.; outline subovate, valves regularly rounded, 
the ventral being the more convex. Ventral valve with an erect, straight beak; apex acute, cardinal margins sloping rapidly forward, and slightly excavate. Foramen simple, triangular, free from deltidial plates, encroaching at its apex slightly upon the umbo ; foraminal margins somewhat thickened. Dorsal beak erect but inconspicuous, full and rounded. Dorsal valve depressed anteriorly along the median line, this depression correspond. ing with the broad and low dorsum of the opposite valve. Surface of each valve marked by eight single, rounded plications, which extend two-thirds the distance from the anterior margin of the beak, leaving the circumbonal area smooth.

\section{DEVELOPMENTAL VARIATIONS}

General Form and Outline. As growth advances, the development is more rapid transversely than longitudinally, and, consequently, the subovate incipient shell becomes, at maturity, broadly transverse. The prominent dorsum of the ventral valve in the embryo, is manifest at maturity only in the rounded and prominent beak, and the embryonal sinus in the dorsal valve becomes so thoroughly obsolete at maturity as to be unnoticeable. In stages of development between the dimensions $3.5 \times 3 \mathrm{~mm}$. and $6 \times 5.5 \mathrm{~mm}$., the ventral valve still retains a slightly greater convexity, but the anterior margin is entire.

Beak and Foramen. The erect "and straight beak of the incipient shell becomes slightly incurved toward maturity, but the cardinal area remains high, exposing the triangular foramen at all stages of growth. Deltidial plates make their appearance early, but never develop sufficiently to meet and inclose the pedicle-aperture, a feature indicative of arrested development, and equally true of the other members of the genus here discussed.

Plications. The fact that the eight plications on each valve of the incipient shell do not reach the umbones, indicates that the initial shell may have been smooth, as we have shown it to be in $R$. indiancnsis. The 
subsequent addition of plications takes place slowly and from the cardinal margins.

\section{RirynchonelLa indianensis, Hall, i 863}

Plate III, Figs. I 7-28

\footnotetext{
—- - Hall. Twenty-eighth Ann. Rept. N. Y. State Mus. Nat. Hist., p. 163, pl. 26, fiǵs. 12-22. 1879.

-_- Hall. Eleventh Ann. Rept. State Geol. Indiana, p. 306, pl. 26, figs. 12-22; pl. 27, figs. $4-6 . \quad 1882$.
}

Rhynchonella indianensis is, beyond a doubt, the most prolific species in the rich fauna of the Waldron beds, and by virtue of this fact, we have been enabled to ascertain the developmental phases through illustrative series of exceptional completeness. It is noteworthy that the mature shell of this Rhynchonella presents variations from the adult type, which are so great that in a certain sense they might be regarded as passing the limitations of specific identity; however, the general form and expression of the shell are characteristic, so that, in spite of these variations, no confusion with allied species of the same fauna can arise, nor need there be any hesitation to assign to the different forms a varietal significance only. Probably ten thousand individuals of this species have passed under our observation, and of this large number, fully one-half have been immature forms.

\section{SPECIFIC CHARACTERS}

Normal Mature Form, containing two plications in the sinus of the ventral valve (plate 3 , fig. 2I). Shell subtriangular or broadly ovate; length nearly equal to, sometimes slightly exceeding the width. Umbo prominent, subacute; cardinal slopes extending one-half the length of the shell, and flattened.

Ventral valve depressed convex, rounded at the beak; apex pointed and slightly incurved, exposing beneath it the elongate, narrow foramen and the inconspicuous deltidial plates. Dorsum for the first one-third the length of the shell rounded, thence, anteriorly, gradually becoming de- 
pressed. The sinus thus formed bears two strong, rounded plications which are of later origin than the pair which forms its lateral boundaries. The latera bear each three plications with traces of a fourth, making eight (ten) on the entire surface of the valve.

Dorsal valve somewhat deeper than the ventral, flattened above, depressed near the beak along the median line (embryonal sinus), thence forward, becoming gradually elevated into a fold which bears three strong rounded plications. Four similar plications are discernible on each of the latera, making in all eleven plications on the entire valve. Umbo inconspicuous, apex concealed within the foramen of the opposite valve. Concentric growth-lines obscure, or absent. Average dimensions I $2 \times 12 \mathrm{~mm}$.

These are assumed as the normal characters of adult growth on account of the great predominance of specimens bearing two plications in the ventral sinus.

Variations from the Normal.

A. Forms with one plication in the ventral sinus. This variation does not attain quite the size of the average normal adult, but retains the same proportion of length and breadth (size Iox Io mm.). The surface bears ten plications on the dorsal and nine on the ventral valve. In this form, the embryonal sinus, visible on the earlier portion of the dorsal valve, is distinctly continuous with the strong sulcus separating the two plications on the fold in the later and marginal portions of the valve. This variation is not of uncommon occurrence, and immature individuals in various stages of development prove that it is a well-established genetic difference, and not merely an occasional monstrosity.

B. Forms with thrce plications in the ventral sinus. The size and proportions of the normal are retained in this variety, but the shell bears usually three, sometimes four plications on each of the latera, making ten (twelve) plications for the dorsal, and nine (eleven) for the ventral valve. This form is of comparatively rare occurrence, and is not often noticed in an immature stage of growth. 
C. Forms with four plications in the ventral sinus. This variation is met with very infrequently, but two individuals having been obtained. While agreeing in size with the normal adult, the crowding of the sinus with pli. cations tends to obliterate both it and the fold upon the opposite valve. Both individuals show the interesting fact that upon the dorsal valve where the fold bears five plications, i. e., four sulci, the embryonal sinus is continuous with the third of these sulci, in one instance numbering from the right, in the other, numbering from the left. Of the five plications which are thus separated into groups of three and two, it is noticeable that the outer member of the group of three is both less elevated and shorter than any other upon the fold.

Monstrous Forms. The sole evidence of monstrous growth that has been observed is an asymmetrical development of the plications upon the dorsal fold. Examples bearing three plications upon the fold, in rare instances have one of the plications very large and two quite small, making one broad and one narrow sulcus upon the fold. The phenomenon may be due to the strongly developed tendency of the embryonal sinus to maintain its continuity with a median sulcus even at the expense of the symmetry of the shell.

Initial Shell (plate 3, figs. I 7 , i $7 a$ ). The initial shell in our series of Rhynchonclla indiancnsis measures $.65 \mathrm{~mm}$. in length by $.54 \mathrm{~mm}$. in width. It is broadly ovate or subpyriform in aspect, convex posteriorly, and depressed toward the anterior margin. Ventral valve with the umbo prominent, the beak elevated and erect, with the apex rounded; cardinal margins rapidly sloping. Foramen subtriangular, apical portion broader than usual in the incipient stages of plicate shells; margins not thickened; deltidial plates absent. Dorsal valve with a rounded, inconspicuous beak. Surface of both valves quite smooth. A median depression is noticeable on the dorsal valve near the anterior margin, making this margin sinuate. This embryo is the smallest that has been found for any of the series 
of Rhynchonellas, and not only on account of its minuteness, but also from the entire absence of plications on its surface and from the elementary character of the cardinal area, we are inclined to regard it as the actual elemental or initial shell.

\section{DEVELOPMENTAL VARIATIONS}

General Form and Outline. The adult variations from the normal, noticed above, seem to be in most instances, and probably would prove to be in all, preceded by well-defined embryonic series leading up to them. This must be the case, as the character of these variations, i. e., variation in the number of plications on the median portions of the shell, is such that they cannot be assumed. after the attainment of the adult condition, as is possible in certain other forms of variation. But it is not to be assumed that the conformation of the embryo which eventually produces any of these results, manifests them in the earliest stages of the growth of the shell, rather, that the shells, under whatsoever variations at maturity, all have the same unspecialized starting point. Hence, the fact that some of these variations have not shown a complete series of immature stages must be due to the insufficiency of our material, rich as it has been.

Limiting our considerations now to the normal form with two plications in the ventral sinus, we notice that the initial shell is smooth, and obcordate in outline, with beak erect, while the mature shell is strongly plicate, strongly ovate and with the beak sharply incurved. The transition from one extreme to the other is through stages of growth between the limits $.65 \times .54 \mathrm{~mm}$. (initial) and $12 \times 12 \mathrm{~mm}$. (average adult). In growth-stages below $7 \times 5 \mathrm{~mm}$. dimensions, the shell is very depressed-convex, the dorsal valve up to about this point, retaining a low, broad, median depression, accompanied by a similarly low and broad median elevation on the opposite valve. It is not always possible to determine with accuracy how many plications are carried by this embryonic fold and sinus, on account of its not being well limited, but their eventual reversion, in the adult shell, into 
sinus and fold, respectively, marks the feature as an interesting one, to which we call attention more at length in the description of the species Rhynchotreta cuneata and Atrypa reticularis. Rare instances occur of individuals assuming all the characters of maturity before attaining a length of $6 \mathrm{~mm}$., and from this point upward to the normal size for adult growth, mature dwarfs are frequently found.

Beak. In the initial shell, the beak of the dorsal valve is rounded and inconspicuous, and so remains in all stages of growth. In the opposite valve, the beak is at first high, erect but not acute, the cardinal margins sloping abruptly, and with increasing age the beak becomes fuller, more and more incurved at the apex, but is never closely procumbent upon the dorsal umbo, as is the case in maturity with most of the plicate species here described.

Foramen. At the outset the pedicle-aperture is narrowly subtriangular, reaching to and encroaching upon the apex, free of deltidial plates and with the lateral margins unthickened, i. e., elemental in every respect. In the second stage of growth (after the appearance of plications on the surface, dimensions $1.5 \times 1.1 \mathrm{~mm}$.), the apertural margins have become thickened, and directly thereafter, the deltidial plates begin to develop, gradually narrowing the aperture at the base. The symphysis of these plates with the valve is marked by distinctly elevated lines. In maturity, the deltidial plates have developed sufficiently to completely close the lower part of the aperture, coming together behind the beak of the dorsal valve, and giving to the foramen an elliptical outline constricted toward the apex, where it encroaches upon the umbo. The fact that the development of the foramen is thus interrupted before it reaches the circular outline normal to the adult of most paleozoic species, indicates an embryonic character in the adult, and, therefore, a subordinate taxonomic position for the species.

Plications. These appear only after the first stage of growth is passed and after the first growth-line has been formed. As in Retzia cvax, 
they appear over the entire surface of the shell below the growth-line all at once, and from this stage onward to maturity, no increase is made in the number, except by intercalation along the margin of the fold and sinus.

\author{
Rhynchotreta cuneata, Dalman, i 827 \\ var. AMERicana, Hall, 1879 \\ Plate IV, Figs. 12-22
}

, Hall. Twenty-eighth Ann. Rept. N. Y. State Mus. Nat. Hist., p. I67, pl. 25, figs.
29-38. 1879.

The individuals of this species do not so readily separate into three groups of long, normal, and broad forms, as do those of Rhynchonella neglecta, Retzia evax, Meristina nitida, and others. This seems to be due to the uniformity in the number of plications, and also in the number carried on the fold and sinus. The long and broad varieties do exist, however, but are of such infrequency as to suggest that they are not genetic variations from the typical form occurring in this locality.

The specimens from the Wenlock shales of Dudley, show a considerable variation from their American congeners, in having more numerous plications, of which a greater number is raised on the dorsal fold and depressed in the ventral sinus. In other respects, it is believed that the description here given, of the development of the shell, will apply to the British form.

Rhynchotrcta cuncata, although considered as abundant in the mature state, does not approach in the number of young specimens, Rhynchonella whitii, R. neglecta, R. indianensis, Retzia evax, Moristina nitida, Spirifer crispus, Sp. crispus, var simplex, Atrypa reticularis, Orthis hybrida, and O. clegantula. The entire number of young individuals examined is about one hundred and fifty, ranging in size from $8 \mathrm{~mm}$. to $1.5 \mathrm{~mm}$. in length. The mature forms average about $17 \mathrm{~mm}$. in length. 
In the several series selected from the material at hand, it is evident that the shell assumed the characters and form of maturity when reaching a length of about ro $\mathrm{mm}$. At this period of growth, the fold of the dorsal valve becomes elevated, and the sinus of the ventral valve depressed (fig. 15 , plate 4 ). Previous to this stage, the dorsal valve is depressed and transversely concave, and the plications of the opposite valve are raised along the median line of the shell.

\section{SPECIFIC CHARACTERS}

Mature Form (plate 4, figs. I4, I 4a, I4 $b, 22,22 a$ ). Shell triangular, cuneiform, widest across the pallial region. Length equal to about twice the depth of the valves. Beaks compressed laterally, attenuate and pointed.

Ventral valve moderately convex, subangular along the latera, marked by a deep sinus, which commences near the middle of the length, and becomes very marked in front, depressing three plications, of which the middle one is detruded more than the others.

Dorsal valve convex, gibbous in the posterior part, with the latera elevated and subangular; marked in front by a prominent fold which begins near the beak as a depression carrying four plications, of which the two central ones are usually much more elevated than the other pair.

Area high, closed by two triangular deltidial plates. Perforation of the ventral beak ovate, truncating the apex, and limited below by the deltidial plates.

Surface marked by from eight to ten strong, angular plications, which are crossed by very fine, regular, sharp, concentric strix. Mature specimens usually measure from io to $7 \mathrm{~mm}$. in length.

Incipient Form (plate 4, figs. I2, I 2a). The youngest shell detected has a length of $1.5 \mathrm{~mm}$., is flattened, and nearly circular in outline. The dorsal valve is depressed in the middle, and carries four plications. The beak of the ventral valve is broadly triangular, exsert, and elevated, with a triangular, open area without deltidial plates. 


\section{DEVELOPMENTAL CHANGES}

Contour. In the earliest stages yet noticed, the shell is nearly circular. At a length of $2 \mathrm{~mm}$., it is broadly oval, and at $2.5 \mathrm{~mm}$., it is ovate. The beak in the next advanced stage is more elongate, and when the length of $4 \mathrm{~mm}$. is reached, the shell has a decidedly triangular or cuneate form, which becomes more pronounced up to maturity. All the young and adolescent shells are depressed, the characteristic fullness of the valves not being developed until after the assumption of the features of maturity, and when the shell approaches its normal size.

Fold and Sinus. The smallest individual shows a slight depression in the dorsal valve, co-existing with the plications, beginning about one-fifth the length of the shell in front of the beak, widening rapidly, and becoming more defined upon approaching the margin. The latera are nearly flat. The depression, or sinus, becomes more pronounced with the advancé in growth, until a length of $4.5 \mathrm{~mm}$. is attained. After this period, the four bottom plications gradually elevate, the sinus grows shallower, and the front margin of the conjoined valves becomes nearly straight. Upon reaching a length of $9 \mathrm{~mm}$., the two central plications are sufficiently elevated to define the fold, which is hereafter the principal feature of the dorsal valve. The development from this point to full-grown individuals is principally directed to reaching a maximum prominence in the fold, and increasing the shell by increment on the lateral margins of the valves.

The development of a sinus in the dorsal valve, its subsequent obliteration, and the firal elevation of the plications into a strong median fold, are shown in figures $15, I-10$ of plate 4 , in which the undulating lines represent the anterior junction of the valves.

Beak. The apex of the dorsal valve is strong and pointed, and is visible in all specimens up to a length of about $14 \mathrm{~mm}$. After this stage, the shell becomes obese, and the consequent greater inclination of the beak, forces it into the foraminal cavity, where it becomes hidden by the deltidial plates. 
The ventral valve is uniformly convex in all incipient specimens. The sinus develops at the same period, and in conformity with the fold of the opposite valve. The beak of the initial shell is broadly triangular, perforate at the apex, and directed outwards. It gradually becomes narrower and less oblique with advancing growth, and lies in the axis of the shell in fullgrown specimens. The initial perforation is a small truncation of the beak, confluent with the open area below. (See figure 16, plate 4.)

Surface ornaments. The prevailing number of plications is eight, although it varies from seven to ten in some specimens. The entire number appears at an early period of growth, and in this respect, the species offers a marked difference from some of the forms of Rhynchonella already considered, in which the plications increase by pairs. In a specimen $1.5 \mathrm{~mm}$. long, they first appear at about one-fifth the length of the shell from the beak. Four plications are included in the depression of the dorsal valve in the incipient stages, and the two central ones finally become elevated, forming the fold in the full-grown shell. Upon approaching maturity, three of the plications in the ventral valve are depressed, the middle one ultimately much more than the others, forming the single strong plication at the bottom of the sinus.

No concentric striæ are shown on the initial shell of our series. In a specimen $3 \mathrm{~mm}$. in length, these begin to develop over the outer third of the surface, as shown in figure 13 , plate 4 .

Cardinal area. The foramen is at first a broad triangular opening, wider than high, with sharp margins, and truncating the beak of the ventral valve. The lateral margins are thickened in a specimen $3 \mathrm{~mm}$. in length (plate 4, fig. I3), and the height and width of the area are equal. These proportions of height and width are preserved to maturity, although in some specimens the area is higher than wide. No deltidial plates have as yet appeared, but in the next stage, including individuals having a length of $4.5 \mathrm{~mm}$., there are two narrow deltidial plates developed from the sides of 
the foramen (plate 4 , fig. I 8 ). A specimen $5 \mathrm{~mm}$. in length shows the still further increase in the size of these plates, although they do not come in contact, but leave an oval opening extending from the ventral beak down to the beak of the dorsal valve (plate 4 , fig. 19). The increase in the growth of the deltidial plates along their inner margins brings them in contact under the dorsal beak, in specimens having a length of about $7 \mathrm{~mm}$. (plate 4, fig. 20). Further growth truncates their inner angles, thus shortening the deltidial opening. In individuals about $\mathrm{I} 2 \mathrm{~mm}$. long (fig. $2 \mathrm{I}$ ), the opening extends but little more than half the length of the area, and the lower margin of the opening is thickened and slightly deflected. Fully matured forms, having a length of from 15 to $17 \mathrm{~mm}$., have a perforation less than one-half the height of the area, which truncates the beak more strongly than in younger shells, and the deltidial plates show a defined thickened area below the perforation, often extending to the dorsal beak (plate 4, fig. 22).

Variations. As already stated, the elongate and broadly flabellate shells appear to be, in this species, neither common nor genetic variations. Among the extraordinary developments are specimens with duplicate plications in the sinus, and one showing but seven plications on the shell. Another individual has the initial shell strongly defined by a varix of growth, and shows on this portion ten plications, but in the subsequent growth, only eight plications are continued, these alternating at the varix with those of the embryonic shell.

Atrypa reticularis, Linnæus, 1767

Plate Vi, Figs. I2-20

- - Hall. Twenty-fourth Ann. Rept. N. Y. State Mus. Nat. Hist., p. 162. 1879.

- - Hall. Eleventh Ann. Rept. State Geol. Indiana, p. 304. 1882.

The abundance of this well-known species at Waldron has afforded the means of studying its developmental stages with very satisfactory results. All the individuals, from the earliest observed stage upward, agree in con- 
tour, there being no such variation in this respect as has been noticed in some other species (e. g. Retzia evax, Mcristina nitida) in which appear deviations from the normal, producing a long type and a broad type. The youngest individual detected has a length of $2.25 \mathrm{~mm}$. and a width of $2 \mathrm{~mm}$., though this may not be regarded as the initial shell on account of the presence of partially developed deltidial plates. From this stage of growth to maturity, the material has afforded every variation in size and structure.

\section{SPECIFIC .CHARACTERS}

Mature Form (plate 6, figs. 13, 1 $3 a, 20,20 \alpha$ ). Atrypa reticularis is so widely distributed, historically and geographically, in paleozoic faunas, and is so familiar to paleontologists, that a detailed description here of its mature form is unnecessary. It is sufficient to remark that the prevailing expression at this locality does not precisely conform to the type of A. reticularis, but is more nearly that variety described by Professor HALl (Palæontology of New York, Vol. 2, p. 271, 1852) under the name Atrypa rugosa. This is evident from the development of the varical lamellæ, which, over the plications, are infolded into nearly tubular processes, sometimes produced at a strong angle from the shell to a length of a millimeter or more. On the varices, the plications are covered by fine concentric wrinkles. The average size of mature individuals, $25 \times 25 \mathrm{~mm}$., is less than that usual to the species, when occurring in later, especially Devonian, faunas.

Incipient Form (plate 6, figs. 12, 1 2a, 15, 15a). . The initial shell, or the actual inchoate period in its formation, is not known to us. The incipient shell of our series is very small, and can be but a few removes from the initial stage. As just observed, it measures $2.25 \mathrm{~mm}$. in length by $3 \mathrm{~mm}$. in width, and shows but two concentric strix, or growth-varices, with a correspondingly slight development of the deltidial plates, so that we are inclined to regard this shell as but two stages advanced from the actual 
inception of the shell. The test is flat, both valves being shallow and depressed toward the anterior margin; the ventral beak high and erect, the dorsal beak inconspicuous and rounded. 'The foramen, which is undoubtedly triangular in the initial shell, has, at this stage, its basal angles slightly rounded by the faintly developed deltidial plates. The plications are six in number on the ventral, and five on the dorsal valve, the middle one of the latter not reaching so far toward the beak as those adjoining it, and toward the anterior margin being depressed below the lateral portions of the shell. General outline subcircular or subpentagonal, as in the fullgrown shell.

\section{DEVELOPMENTAL VARIATIONS}

General Form and Outline. Embryos of less than $3 \mathrm{~mm}$. in length are more nearly circular in outline than at any subsequent period of the existence of the individual. Directly thereafter, the hinge-line represents the greatest diameter of the shell, and the outline becomes subpentagonal, a feature which is more apparent in young individuals having between 3 and so $\mathrm{mm}$. length, as the increasing rotundity of the shell with the approach of maturity has a tendency to obscure, in a measure, this outline. At the earliest stage studied, the dorsal valve is distinctly depressed along the median line, forming a sinus containing a single plication which does not reach to the beak (plate 6, fig. 14a). This sinus gradually becomes shallower, and the plications are increased by intercalation until they are three in number (fig. 14b). In the next stage, all evidence of a sinus upon the anterior margin disappears, leaving it even and straight as shown in figure $14 \ell$; then the anterior edge becomes reflexed, showing, in subsequent stages of growth, a fold where there had previously been a sinus, this fold bearing at first three, then five, and eventually, in the mature individual, seven plications (fig. $\mathrm{s} 4 d, e, f$ ). This very remarkable reversion of the fold and sinus relatively to the valves which bear them, is also seen in the species Rhynchotreta cuneata and, in all adult specimens, may be clearly traced upon the earlier or embryonal portions of the valves. 
Beak. In the first stage, the ventral beak is high and slightly resupinate, exposing the foramen in an inclined plane. It gradually shortens and becomes erect, and when the shell attains a length of $8 \mathrm{~mm}$., it is bent forward, the cardinal area being slightly incurved. Thereafter, the inflection of the area increases, concealing first the deltidial plates, and finally the foramen, until, in maturity, the beak lies appressed upon the embryonal sinus of the dorsal valve.

Foramen. In the initial shell, this is undoubtedly triangular and free from deltidial plates. With the starting point of our series, however, plates have begun to develop, thus narrowing the pedicle-aperture, and rounding its basal angles. With the growth of the plates more rapidly along the lower portion of their inner edges, the foramen shortens quickly, while narrowing but slowly, assuming in the second stage (fig. I6), a lanceolate, in the third stage (fig. I 7), an oval, and in the fourth stage (fig. I8), a broadly circular outline. In the last two of these stages, the deltidial plates have come in contact with each other above the apex of the dorsal valve, and the pedicle-aperture itself has, from the second, if not from the first stage in the series, encroached upon the apex of the valve, so that, as it attains a circular outline, one-half its periphery is formed by the substance of the valve itself, and the other half by the deltidial plates. From this stage upward, there is no apparent change in the actual dimensions of the foramen, and, therefore, with the growth of the shell it becomes relatively much smaller. It appears, however, that with the incurving of the cardinal area and the concealment of the deltidial plates, the foramen becomes more and more inclosed by the apical portion of the valve, and it may be that actual contact with the deltidial plates in the last stage of development is lost. In this final stadium, with the procumbent position of the ventral beak upon the dorsal valve, the plane of the foramen is parallel to the surface of the dorsal valve, and the aperture is therefore lost to sight, or visible only at its upper edge. 
Plications. Of the five and six plications visible upon the youngest member of the series, three or four appear to exist on that portion of the shell included within the earliest growth-line, i. e., presumptively, the initial shell, and they increase by intercalation until, in the adult, the average num. ber is about sixty for each valve. Concentric lines of growth follow each other with unusual rapidity, particularly in early life

Summary. Atrypa reticularis, in the development of its beak, foramen, and deltidial plates, is in essential harmony with the other uniforaminate-shells here discussed The reversal of the fold and sinus is an interesting but not unique feature, and by the time it has been completely effected many of the characters of maturity have been assumed. From the degree of exposure of the foramen, we judge that the animal remained attached by its pedicle up to adult growth, but with full maturity and the approach of senility, the pedicle must have become atrophied and the animal set free.

Retzia evax, Hall, i 863

Plate V, Figs. I-9

- - Hall. Twenty-eighth Ann. Rept. N. Y. State Mus. Nat. Hist., p. 160. 1879.

- - Hall. Eleventh Ann. Rept. State Geol. Indiana, p. 302. I882.

In this species, the superficial features have been-found of much more permanent character than is usual in the plicate brachiopoda from this horizon. Not far from three thousand individuals have been examined, and these show a variation in size from a length of $\mathrm{I} \mathrm{mm}$. and a width of $.8 \mathrm{~mm}$., to a length and width of $25 \mathrm{~mm}$. Throughout the younger stages in this series of variations, the feature of primary importance in distinguishing the embryo of this from those of other species, notably Retzia sobrina Rhynchonella indianensis, and Rhynchonella whitii, is the sinus which exists on both ventral and dorsal valves; and of much accessory value, the comparatively slight variation in the number of the plicatiøns on the lateral portions of the valves. These features will be presently adverted to more at length. 


\section{SPECIFIC CHARAC'TERS}

Mature Form (plate 5, figs. 2, 2a). Shell ovate, generally longer than wide, both valves almost evenly convex, and of about the same depth. Anterior margin generally slightly emarginate, on account of the median sinus which exists on both valves. In rare instances, a low.median fold is developed near the margin of the dorsal valve.

Ventral valve with the beak much elevated above the dorsal, and incurved, so that the plane of the foramen is parallel to the axial plane of the shell. Foramen circular, or slightly subtriangular; deltidium generally obscure on account of the infolding of the beak, but showing the triangular deltidial plates.

Dorsal valve regularly arcuate, except at the posterior extremity, where the beak is closely incurved beneath the ventral umbo. The median sinus usually carries from three to five plications, but sometimes becomes filled up, in advanced growth, by the crowding of these plications. Ventral valve with a well-marked sinus, generally bearing three plications. The sinal plications on both valves take their origin in front of the beak, and are of interstitial growth, a fact which does not hold true for any of the other plications. The surface is marked by from eight to twelve rounded, continuous plications on each side the sinus of either valve, all of these extending to the beak, with the possible exception of the more obscure ones on the cardinal slopes. Only in rare instances and abnormally, do these plications increase by interstitial addition. Imbricating lines of growth are often present, and fine concentric striæ are sometimes discernible.

The mature individuals of Retzia evax divide themselves into three groups, based on their relative proportions:

(a) Normal form, in which the length and width are equal.

(b) Long form, in which the length is greater than the width.

(c) Broad form, in which the length is less than the width.

In frequency of occurrence, the form $(b)$ almost equals the normal, 
while the form $(c)$ is more rarely met with. The form $(b)$ is also of remarkable persistence, and starts so early in the life of the individual as to suggest a distinct genetic impulse.

Variations from the normal development. These are to an unusual degree very slight, and may be classed as follows :

Obesity, which apparently occurs only when normal full growth has been attained.

A tendency to asymmetry in development of the sinal plications. A marked illustration of this is afforded by an individual which, in repairing an injury to its shell, has abruptly developed six plications on one side of the sinus, in continuation of three and to correspond with three on the opposite side.

The absence of plications in the sinus. This is a feature of rare occurrence, and is undoubtedly an infantile character retained in later stages of growth. A single individual of immature growth affords an illustration of a peculiar abnormality, indicating a reversal in the growth to an embryonic condition. This shell (plate 5, figs. $3,3^{a}$ ) has grown to a certain size and normally developed its plications, but an abrupt period has been placed to their development, and over the entire anterior portion of the individual, in front of a stout varix, the surface of the shell is almost smooth. This is the exact counterpart of that mode of growth, to which attention is called under other species, where the smooth embryonic condition of the shell seems to be prolonged for more than the usual period of immaturity, and the mature features are thereupon abruptly developed after the formation of a sharp growth-line.

\section{DEVELOPMENTAL VARIATIONS}

Our series of individuals illustrating the embryological changes in this species is so complete as to show by almost imperceptible gradations the entire chain of development from very near the starting point up to maturity. This series begins with an individual measuring $\mathrm{I} \mathrm{mm}$. in length and 
$.8 \mathrm{~mm}$. in width, and at this stage of growth, the incipient shell has mani. festly not received much increment. That this, however, is not the actual primitive shell seems proven by indications of two very indistinct concentric growth-lines, and by the presence of faint radiating plications near the anterior margin, between the second growth-line and the margin itself. It is very probable that the incipient shell consisted of that portion of the individual (plate 5, fig. I) lying within the first growth-line, and as this would make its size about $.5 \times .4 \mathrm{~mm}$., this fact in itself is sufficient apology for our not having detected the earliest stage of its development, even if other causes had permitted its preservation.

Beaks. In all normally developed individuals less than $5 \mathrm{~mm}$. in length, the beak of the ventral valve is erect and exsert. At about this stage of growth, a tendency to apical incurvature is manifested, which increases up to maturity, when, under normal development, the entire umbo is evenly incurved, concealing the deltidial plates and often much of the foramen. On the dorsal valve, the beak is quite obscure in the youngest forms, and in later stages of growth is concealed beneath the deltidium or incurved beak of the opposite valve.

Foramen. This appears first as a simple triangular opening, its apex reaching to, but not truncating the apex of the umbo, and it is retained in this condition until the shell attains a length of at least $3 \mathrm{~mm}$. of normal growth. At this age, the deltidial plates begin to form, making their first appearance as two minute triangular laminæ, taking their origin in the basal angles of the foraminal triangle, and giving the foramen a lanceolate outline.

By increments to their internal edges, these plates presently come in contact with each other, truncating the interior basal angle of each, the plates being, from this period onward, in progressive symphysis. The increments to these plates are made more rapidly at and about their interior angles, and as a result, the foramen assumes successively an elliptical, an 
oval, and a circular outline. The circular curve of its upper extremity is caused by a slight encroachment upon the beak, and this in mature age is so considerable that the primary or incipient shell is undoubtedly wholly absorbed. The plane of the foramen remains, except in rare instances, always vertical, although the deltidial plates become slightly bent by the incurving of the beak. A striking exception to this rule is represented on plate 5 , figure 9 , where an individual which has reached early maturity shows the senile feature of a beak incurved to such a degree as to almost obscure the foramen. On approaching maturity, the deltidial plates appear to become anchylosed along their exterior edges, with the shell itself, the line of union being marked with a low ridge, and we have never seen them displaced by any distortion of the shell, as so often occurs in Colospira disparilis.

Sinus. As already noticed, the sinus, in the elementary shell, begins as a low, smooth depression, equally strong on both valves, and extending almost to the beak. It gradually becomes filled by the radiating plications, which appear first at the sides, and increase toward the middle, never becoming, normally, more than six. None of these plications reach the apex of the shell.

Plications. On the latera of the shell, these seem to appear simultaneously, as shown in figure 1, where three on each side make their appearance at the same stage of growth. This number is subsequently increased to six or eight on each side in mature forms, sometimes becoming greater in old age.

Internal Apparatus. The brachial supports in this species consist of spirals, coiled in the transverse axis of the shell, with their bases facing each other. In the mature individual, the number of coils is from eight to ten. The spirals are connected by an angular loop, the branches of which take their origin on the dorsal limb of the basal coils, and are directed ventrally and backward to beyond the axis of the interior cavity, forming at 
their junction not a simple angle, but a miniature saddle, from the posterior extremity of which extends straight backward a little spiniform process. The number of coils in these spires varies with the age of the shell. In preparing a series to show the development of these structures, it appears that the shelly ribbons composing the spirals not only make fewer coils in early life, but that these are of exceeding tenuity in the primary stages of development. The accompanying figures show the extremes of development noticed in these respects, figures $\mathrm{I}$ and 2 representing the character of the supports in the mature condition, and figure 3 , the spirals as developed in an individual having a length of $2.5 \mathrm{~mm}$., where the ribbon makes but
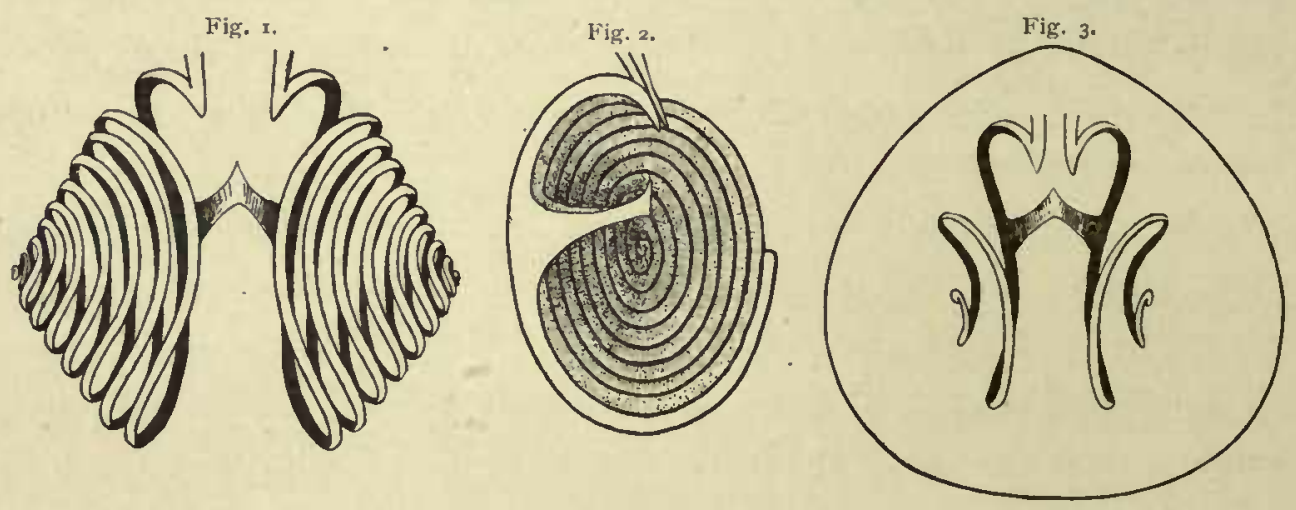

Fugs. 1, 2, 3. Development of Internal Apparatus in Retzia Evax.

two revolutions. As far as can be ascertained, the loop undergoes no essential modification in these early stages, though its precise character in the example from which this drawing has been made, was not determined, but has been drawn in. The same arrangement, however, has been seen in an individual of but slightly larger growth.

The growth of these spirals consists, primarily, in the addition to the number of coils, and, secondarily, in the thickening of the ribbon. In the first case, the increase in number must take place by addition to the apices of the coils, and, therefore, the embryonic or primary coils of the ribbon must be wholly concealed by later depositions upon them, both in length and width. The apparent looseness of the coils in their primary condition 
must, however, be regarded as largely due to magnification, the distance between successive coils being actually not so great as the distance between the apical turns of the ribbon in the mature spiral.

Rhynchonella whitii, Hall, in part.

RETZIA SOBRINA, sp. nov.

Plate V, Figs. 10-16

In the examination of a large number of the specimens which have usually passed under the name of Rhynchonella whitiz, we have become convinced, that, aside from the individuals which agree with the types and the description of the species, there is a series of shells, which, in the mature state, may be readily confounded with immature stages of $R$. whitii, but in their immature condition are readily separable from this species, and form, of themselves, a satisfactory and well-defined developmental series. The similarity of these examples with $R$. whitii is found in the general outline, the strong, simple plications approximately the same in number, and the usual two plications on the median fold. The external differences, however, in the new species, are these: the plications on the fold may be one or three, and whatever their number, the fold is always depressed, in most instances even to obsolescence, and the plications upon it are low and often faint. The foramen, also, is circular in maturity, with perfectly developed deltidial plates, and the surface of the valves usually conspicuously marked by fine, crowded, concentric growth-lines. Internally, the difference is more emphatic, as carefully prepared specimens show well-defined spirals having their apices near the lateral margins, as shown on plate 5, figure I2. While disavowing the intention of describing new species as remote from the purposes of this paper, we have, for convenience's sake in utilizing this form for our work, to which it makes no unimportant contribution, designated it as above, as no doubt exists of its specific value.

Retzia sobrina, one of the more abundant of the Waldron brachiopoda, is itself subject to some variation, more considerable indeed, than that no- 
ticed in either of the species Rhynchonella whitii and $R$. neglecta. Our material represents all developmental stages between the limits of these dimensions; $2 \times 1.6 \mathrm{~mm}$. (incipient shell) and $7 \times 6.5 \mathrm{~mm}$. (maturity). In its youngest stages, it shows a certain degree of similarity with Retzia evax, especially in the sinus on both valves, and in the sinal plications. The greater number of the latter in $R$. evax, as well as the more numerous lateral plications, will serve to obviate confusion here.

SPECIFIC CHARACTERS

Mature Form (plate 5, figs. i , I $a$, i $b$ ). Shell small, rotund, in outline broadly ovate to subpentagonal. Valves of equal convexity.

Ventral valve with umbo prominent, attenuate, erect, and slightly incurved at the apex; cardinal margins not excavate, sloping with a faint curve to the sides, whence they round to the anterior edge, which, in the sinal region, is nearly straight; cardinal area distinct; foramen circular; deltidial plates prominent.

Dorsal valve subcircular in outline, arched in the umbonal region; beak well-defined, apex concealed. In the umbonal region, the median portions of both valves are slightly more convex than elsewhere, but this prominence disappears toward the margins, the valves becoming slightly flattened and depressed on the median region near the anterior margin, making a low sinus on the ventral, and a low, depressed fold on the dorsal valve. Both fold and sinus may bear one, two, or three small, often faint and unsymmetrically developed plications, the strongest of which may have its origin in the umbonal region, while the others rarely extend more than half-way across the shell. On each of the latera are four or five strong, angular, simple plications, making thus from nine to thirteen plications on each valve. The increase in these takes place altogether on the fold and sinus, the full quota of lateral plications appearing early in the history of the individual. The plications are covered by numerous fine, concentric growth-lines more noticeably developed near the margin, and at intervals becoming varicose. 
The spiral brachial supports each make about five revolutions, which come to an apex near the lateral margins.

Variations from the normal mature form. An elongate form with an unusually high and straight beak is not of rare occurrence, and is the resultant of a very completely represented series of embryonic stages. The species is also subject to obese growth, resulting from two sources; (a) general internal thickening of the shell, $(b)$ marginal thickening. Both are the result of post-adolescent or senile growth, the former producing a round, full, plethoric shell, the latter giving the shell a truncate appearance.

Incipient Form (plate 5, figs. 10, 10a). The first stage of growth represented in our series measures $2 \mathrm{~mm}$. in length by $1.6 \mathrm{~mm}$. in width. The valves are subequally convex, somewhat depressed anteriorly. Outline broadly ovate.

Ventral valve with beak high, erect, and subacute; cardinal slopes broad, steep, and slightly excavate; pedicle-aperture subtriangular, rounded at the apical angle, and also slightly, at the base, by the already developed deltidial plates.

Dorsal valve subcircular, beak full, rounded, sides slightly appressed, apex concealed. Surface of the dorsal valve marked by two thread-like plications which take their origin medially, just below the umbonal region; thenceforward they rapidly diverge, forming the embryonal sinus, which is, however, soon filled by two small plications. The latera each bear one plication, of earlier age than the sinal, and later than the primary plications. On the ventral valve, the plications number the same, but the embryonal fold or dorsum is more strongly marked than the dorsal sinus. On both valves, indications of the mature fold and sinus begin with the appearance of the sinal plications.

DEVELOPMENTAL VARIATIONS

General Form and Outline. There is a gradual increase in convexity and diameter with each successive growth-stage, until maturity is reached. 
The elongate variation from the normal seems to have retained through all stages of growth the proportions of the normal embryo.

Beak and Foramen. The erect, straight, subacute beak of the incipient shell, in later growth becomes rounded and slightly arched or incurved. The cardinal area in all stages of development is, however, high, exceptions being made for the more extreme cases of obesity, where the deltidial plates may be concealed, but the foramen is always exposed, and the beak is never procumbent on the opposite umbo. The plates arising from the base of the thickened foraminal margins, meet in such a manner as to leave the foramen sharply acute below, and subtriangular. By their subsequent upward growth and more complete union, the foramen becomes circular, the lines of symphysis with the valves still remaining thickened.

In occasional instances, a probable slight displacement of the plates outwardly along the median suture, gives them the appearance of sloping away from the median to the lateral sutures.

\section{Colospira disparilis, Hall, i 852}

Plate V, Figs. I7-23

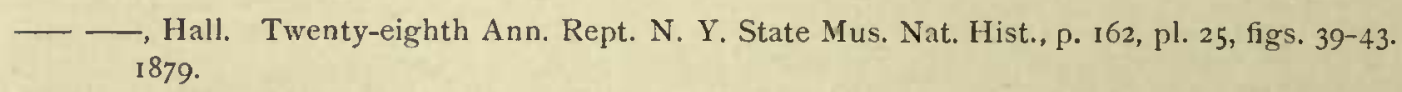

—— Hall. Eleventh Ann. Rept. State Geol. Indiana, p. 303, pl. 25, figs. 39-43. 1882.

Although this species is one of the less abundant nembers of the Waldron fauna, we have found several hundred immature individuals, the youngest of which has dimensions of $2.5 \mathrm{~mm}$. length by $2 \mathrm{~mm}$. width, the greatest size at maturity being $6.5 \mathrm{~mm}$. length by $6 \mathrm{~mm}$. width. The species being, in its mature size, quite small, and, in its surface features, quite simple, it does not afford such scope for variations through the later embryonic stages as many of its associated species and hence, it will be noticed, that in surface sculpture, a permanency of character is retained through all stages of growth. 
Mature Form (plate 5, figs. I 9, I $9 a$, I gb). Shell small, suboval or cordate, often subpentagonal ; plano-convex, greatest width along the hinge.

Ventral valve convex, depressed at the sides; beak exsert, and in old forms arcuate.

- Dorsal valve flat and sometimes depressed near the beak. The ventral valve is marked by two very prominent plications which pass along the deep median sinus, and are accompanied by two less distinct plications on each of the latera, making in all six plications, of which the two nearest the hinge-line are sometimes obsolescent. The dorsal valve bears a prominent median fold, and two well-marked plications on the lateral portions of the shell. Toward the margin are concentric laminæ of growth. An average adult individual measures $5.5 \mathrm{~mm}$. in length by $5 \mathrm{~mm}$. in width.

Variations in Outline. The individuals divide themselves into two groups according to their outline:
(a) normal form.
(b) long form.

The first of these groups includes the great majority of all individuals found, which are characterized by a relatively broad figure and subcircular outline. Members of the second group are comparatively few in number, and are elongate or subovate individuals. The long form (b) is well defined in immature growth-stages, and appears to be a permanent varietal difference.

Abnormalities. A variation in adult shells, noticed only in rare instances, is a tendency to an asymmetrical development in the plications, as shown on plate 5 , figure I 8 , where, by unequal growth upon the lateral portions of the shell, the median plication on the dorsal valve is deflected to one side, and the corresponding median sinus on the ventral valve displaced, the axial line of the shell being occupied by one of the strong plications bounding the sinus. Another form of this asymmetry is manifested in the 
intercalary addition of a single plication on one side of the median plication of the dorsal valve.

A tendency to obesity is often manifested by the shell, at or before reaching the average dimensions of maturity, when it may be supposed that the full growth of the individual has been attained. This obesity is produced by a rapid thickening of the shell at the margins, making the anterior face truncate and forcing the ventral beak over the dorsal in the same manner as if the valves were forced to open along the hinge. It is, therefore, only in individuals which have reached this obese condition that the ventral beak is incurved.

\section{DEVELOPMENTAL CHANGES.}

The character of the primal or elemental shell may be seen from a single example (plate 5, fig. 18), in which the plications are abruptly developed at a distance of $1.5 \mathrm{~mm}$. from the apex, and, presumably, that portion of the shell within this limit, represents approximately the size of the original embryonic shell. This portion of the individual is quite smooth, and shows but a trace of the median fold and sinus. As already observed, there is a marked permanency in the surface features of the species from early youth to maturity. The smallest individual obtainable bears, as in the mature condition, six plications on the ventral and five on the dorsal valve, though those near the hinge-line are quite faint.

The beak is prominent and exsert, except in obese shells, where it is incurved. In the earliest stage where the character of the foramen is well preserved the individual has a length of $4 \mathrm{~mm}$. and a width of $3.5 \mathrm{~mm}$. Here it is seen to be elongate-oval, the deltidial plates having formed to such a degree as to be in contact with each other and to have anchylosed, so that the median suture is detected with difficulty. The lateral sutures always remain distinct even to maturity, and it is evident that the union of the plates with the shell along these joints has not been as firm as in many species, as it is not infrequently found that the plates have been displaced 
and lost. Careful search among the smallest individuals has shown no trace of the inceptive triangular outline of the pedicle-groove existing in other species before the formation of the deltidial plates. It is an important fact that the foramen begins to assume its mature condition so early in the history of the shell, although its development was evidently in conformity with the general type.

The subsequent development of the deltidial plates changes the form of the foramen to that of a circle, as shown in figures 22 and 23 . In the early life of the shell, the plane of the foramen is in, or parallel to, the axial plane; at maturity, before any obesity or senile thickening takes place, the foramen, in becoming less elongate, truncates the apex of the valve, and makes a large angle (sometimes almost $90^{\circ}$ ) with the axial plane; subsequently, with increase in obesity, it becomes again more nearly parallel to this plane. In the last condition, the deltidial plates are curved inwards, and often to a large degree concealed.

\section{Meristella rectirostra, Hall, i 882 \\ Plate VII, Figs. 4, 5, II-I3}

— - Hall. Eleventh Ann. Rept. State Geol. Indiana, p. 30I, pl. 27, figs. IO-I4. 1882.

This small species is one of the less abundant of the brachiopods of this fauna, and probably has often been confounded with undeveloped individuals of Meristina nitida. It presents, however, adult features which will not allow it to be confounded with that species, and although some difficulty arises in separating the diminutive forms of the two species, $M$. rectirostra is characterized by the absence of deltidial plates in every stage of its existence.

The series representing this species does not include stages of growth as early as in some of the others, but is sufficiently complete to permit the statement that, were younger forms accessible, they would probably add little to our knowledge of the developmental changes. The series begins 
with individuals having a length of $2.5 \mathrm{~mm}$. and a width of $1.75 \mathrm{~mm}$., the adult form measuring $9 \mathrm{~mm}$. in length by 7.5 in width.

In all stages of growth earlier than that approximately indicated by a size.of $6 \times 4 \mathrm{~mm}$., it is very difficult, and from our observations impossible, to draw the line of separation between this species and $M$. nitida, and the fact which has been demonstrated for Orthis elegantula and O. hybrida, viz.; that in the earliest growth-stages no specific differences are manifest, will probably be found to hold good for these two species also." And in the latter case a considerably larger size is attained by the embryo forms than is reached by the former species, before the differential characters are assumed. This is due to the fact, that these two species, when mature, have essentially no surface sculpture, and differ less in general form and outline than do the mature individuals of Orthis.

\section{SPECIFIC CHARACTERS}

Mature Form (plate 7, figs. 12, I 2a, 1 2b). Shell subpentagonal or ovate; beak erect, acute, and prominent, rapidly widening toward the base. Lateral margins nearly straight for about one-third the length of the shell, thence rounding to the anterior margin. Valves about equally convex, giving the shell a sublenticular contour.

Ventral valve with attenuate, straight, or slightly arcuate beak. Fora. men triangular and without deltidial plates.

Dorsal valve more nearly subpentagonal in outline; beak incurved into the foramen of the ventral valve.

Surface smooth, or in rare instances showing a faint pseudo.punctate appearance which is entirely superficial. Dimensions of average adult $9 \times 7.5 \mathrm{~mm}$.

* In accordance with the intention already expressed, not to enter into discussions of synomymy and generic values, we have followed Mr. Hall in referring these species (M. rectirostra and $M$. nitida) to different genera. We believe, however, that the character of the loop will prove them to be congeneric. 
Incipient Form (plate 7 , figs. $4,4 a$ ). Shell measuring $2.5 \times 1.75$ $\mathrm{mm}$. Oval, proportionally longer and narrower than in the adult state. Beak elevated, acute; straight. Foramen of the ventral valve very broad, triangular, extending to the apex. Dorsal beak full, rounded and inconspicuous. Shell convex just below the beak, becoming depressed toward the anterior margin.

\section{DEVELOPMENTAL, VARIATIONS}

General Form and Outline. In the incipient stadia of growth, the shell is extremely elongate and quite perfectly oval; the beak of the ventral valve is relatively broad, its lateral margins having a slight outward curve. With growth, the shell broadens, and the ventral beak becomes more attenuate while the greatest width of the shell, instead of being at or below the middle, comes nearer the hinge-line.

Beak. From being erect, straight, and relatively broad in the ventral valve, at the outset, it becomes, at maturity, narrow, attennate, and slightly incurved toward the apex.

Foramen. In the earliest observed stage, the foramen is a broad, triangular opening, covering nearly the entire cardinal area, reaching, but not encroaching upon the apex of the valve. In subsequent stages of development, this opening narrows with the narrowing of the beak, but, as at no stage deltidial plates are developed, the contraction is due to the encroachment of the cardinal portions of the valve along the foraminal margins. The interesting fact of the persistent absence of deltidial plates throughout the entire existence of the individual, may be interpreted as a retention to maturity, of a character embryonic in allied species; the small size of the mature shell and the very slight incurvature of the ventral beak also contribute to the embryonic expression of the species. 


\author{
Meristina nitida, Hall, 1843 \\ Plate Vil, Figs. 6-xo
}

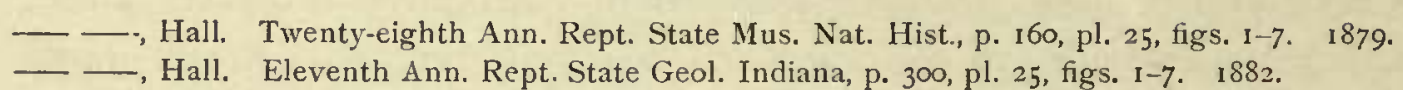

Meristina nitida is a very abundant and characteristic fossil in the Niagara fauna of central Indiana, reaching a much greater development both in size and numbers than in the New York outcrops of the formation. The individuals vary in size from a length of $2.5 \mathrm{~mm}$. and a width of 1.75 $\mathrm{mm}$., to a length of $25 \mathrm{~mm}$. and a width of $22 \mathrm{~mm}$., and the series representing these variations is, on account of the abundance of specimens, very complete within these limits. It is, however, a noticeable feature of the species that in most respects, except size, the characters of maturity are assumed early in the life of the individual, and as the form is essentially devoid of surface sculpture, the interest in its development rests to a larger degree than usual upon abnormalities in individuals either mature, or approaching maturity.

\title{
SPECIFIC CHARACTERS
}

Mature Form (plate 7 , figs. $9,9^{a}, 9^{b}$ ). Shell broadly subpentagonal to ovoid; beaks extended and more or less prominent.

Ventral valve with the greatest convexity at about one-third the length of the shell in front of the beak. Beak arched, incurved over the dorsal valve; apex evenly truncated, the circular foramen lying in a vertical plane. Cardinal slopes extending for more than one-half the length of the shell. A low median depression is noticeable on the younger portions of the valve.

Dorsal valve with a similar convexity; beak incurved and concealed. A very low and inconspicuous median elevation corresponds with the depression on the opposite valve.

Sur face smooth or with fine concentric strix and a few conspicuous lines of growth toward the anterior margin. Average individuals measure $20 x$ $16 \mathrm{~mm}$., large examples not infrequently $25 \times 2 \mathrm{I} \mathrm{mm}$. 
Variations in Outline. Two very distinct groups of forms are evident in this species, in one of which, (a) normal, the outline of the mature shell is obcordate or subpentagonal. When immature, the anterior margin is evenly circular, but in all cases the proportion of lengih to width is essentially the same. Probably five-eighths of the specimens found belong to this group.

In a second group, (b) long form, the shell is elongate-spatulate, and proportionately deeper than the nornal, but, with a single exception, individuals have not been observed to exceed a length of $10 \mathrm{~mm}$. and a width of $7 \mathrm{~mm}$. This variation is so persistent that it appears to be well founded genetically, and not merely an occasional occurrence. Tracing backward from the mature shell to the earlier stages of development, we find both this and the normal form merging into each other, hence both have had a similar starting point. The long form, however, reaches maturity of development at a very early age, and never approaches the size or proportions of the normal adult. A tendency to obesity is especially noticeable in the group (b), the majority of such individuals being below the normal full growth.

A single adult example shows traces of broad, rounded plications on each side of the fold and sinus, a singular condition in a species uniformly non-plicate.

Incipient Form (plate 7 , figs. $4,4 a, 10,10 a$ ). Shell $2.5 \mathrm{~mm}$. in length by $1.75 \mathrm{~mm}$. in width; elongate, oval; beak elevated, straight, acute. Pedicle-aperture of the ventral valve very broad, triangular, extending to, but not encroaching upon the apex. Dorsal beak full, rounded, but inconspicuous. Valves convex just below the beaks, becoming depressed toward the anterior margin. The shell is proportionally much narrower than the adult form.

The starting point of our series is precisely the same form of shell as that taken for the incipient stage in the species Meristella rectirostra. 
Under the discussion of that species, reference has been made to the impossibility of separating these two species, in their earlier stages, and we are left to regard the impression of the specific characters as of subsequent development.

DEVELOPMENTAL VARIATIONS

The surface characters being unvariable, the important changes in development are confined, as far as observable, to the pedicle-aperture and deltidial plates. As already observed, the beak is incurved so early in the history of the individual that these embryological changes can be observed only in very young specimens. This incurvature of the ventral beak appears to become fixed earlier in the normal than in the elongate form. For example, figure 10 , plate 7 , represents an elongate individual with a length of $2.5 \mathrm{~mm}$. and a width of $1.5 \mathrm{~mm}$., with an open triangular foramen, and no apparent development of the deltidial plates, but the normal form of the same size has the plates developed, the foramen nearly circular and the beak incurved. In the condition represented in this figure, the embryos of this species are readily confounded with Meristella rectirostra, in which the triangular aperture is retained until maturity. The latter species is, however, distinguishable in all the later stages of its existence by the body of the shell being broader and the ventral beak narrower and more attenuate.

Individuals which show the deltidium in its different phases are difficult to obtain on account of the tendency of the beak to incurvature as soon as the plates begin to form. An individual is represented in figure 7 , plate 7 , of somewhat abnormal height of beak, showing an intermediate stage of growth in the plates and the formation of the foramen; and in figure 8 , an individual of the same size with the foramen circular, and the deltidium completed and concealed by the infolding of the beak. 


\author{
Whitfieldia maria, Hall, i 863 \\ Plate VII, Figs. I-3
}

Meristella Maria, Hall. Trans. Albany Inst. vol. iv, p. 212. 1863.

Meristina Maria, Hall. Twenty-eighth Ann. Rept. N. Y. State Mus. Nat. Hist., p. 159, pl. 25, figs. 8-12. 1879.

- - Hall. Eleventh Ann. Rept. State Geol. Indiana, p. 299, pl. 25, figs. 8-12. 1882.

*Whitfieldia tumida (Dalman Sp.), Davidson. Supp. Brit. Sil. Brach., p. 107. 1882.

This species may be regarded as presenting a general external form and effect diametrically opposed to that in Meristella rectirostra. To the erect, attenuate, acute beak, open pedicle-aperture, shallow valves, and asinuate anterior margin of the latter, the full, rounded, incurved beak, concealed cardinal area, ventricose valves, and strongly sinuate anterior margin of $W$. maria are strongly contrasted. Between the mature characters of these two species, Meristina nitida is conspicuously mediate.

Immature specimens of $W$. maria are far from abundant. Indeed, our series shows only about thirteen different grades of development, and the smallest individual which can be referred with certainty to the species measures $6 \times 6 \mathrm{~mm}$. (adult $29 \mathrm{~mm}$. in length by $32 \mathrm{~mm}$. in width).

We have, however, assigned to the species a minute embryo measuring $.75 \times .75 \mathrm{~mm}$., and if this is correctly done, the embryos of this species in the earliest stages of growth differ from those of the other non-plicate species here discussed in a much stronger tendency toward a circular outline.

The beak of the ventral valve becomes incurved, and the cardinal area obscured very early, so that the discussion of the development of these parts is necessarily much curtailed.

* The late Mr. Davidson identified the Waldron species with the Atrypa tumida of Dalman, the type of his genus Whitfieldia. We use the term Whitfieldia here for convenience, but if the identity of the American and European forms is established, Atrypa tumida will have been taken as the type of two (Meristina, Hall, Whitfeldia, Davidson), if not of three (Meristella, Hall) genera. 
SPECIFIC CHARACTERS

Mature Form (plate 7 , figs. 3, 3a). Shell comparatively large, ventricose, broadly ovate or subpentagonal.

Ventral valve gibbous in the umbonal region, with a low, broad dorsum extending from the umbo to near the middle of the valve, where it becomes flattened, sinuate, and at the anterior margin is reflected dorsally into a linguiform extension. Beak closely incurved over the dorsal valve, fully concealing the foramen. Cardinal slopes angulate, and slightly excavate.

Dorsal value evenly convex, somewhat gibbous, strongly arcuate transversely along the dorsum, which becomes elevated into a low fold, deeply emarginate in front for the reception of the extension from the opposite valve. Beak obtuse, incurved and concealed.

Surface smooth, marked by concentric growth-lines near the margin.

Occasionally, individuals of large growth show a greater length than breadth, presenting an elongate form, but this variation seems to be due to more rapid axial growth after the attainment of adult size, and does not manifest itself in the incompletely developed shells.

Incipient Form (plate 7 , figs. 1, $1 a, 2,2 a$ ). The minute shell which appears to have been the initial form for the species, has a circular outline and depressed convex valves. The ventral valve is evenly convex, with the beak erect, short, and broad. The cardinal area is low, the foraminal aperture triangular, reaching to, but not encroaching upon the beak. The deltidial plates are absent. Dorsal valve with the beak not incurved but inconspicuous. Neither valve bears any trace of a median elevation or depression.

\section{DEVELOPMENTAL VARIATIONS}

General Form and Outline. An inclination toward a lenticular form and circular outline is noticeable in all immature individuals. Until a size of about $18 \times 18 \mathrm{~mm}$. is attained, there is rarely, if ever, any trace of the strong marginal fold of maturity. 
Beak. The low but erect ventral beak of the initial shell, has, in the next stage of growth, become inflected and obtuse, not, however, so as to conceal the foramen, which remains apparent above the apex of the dorsal valve, until the rapid increase in convexity, which immediately precedes maturity, sets in. Thereafter, the ventral beak becomes more closely incurved, and thrust over upon the dorsal valve, to the loss of all external trace of the cardinal area.

Foramen. The elemental hiatus is shown in the initial shell and the sibsequently developed deltidial plates in the next growth-stage. In the latter case, the foramen has become nearly if not quite enclosed and has also encroached upon the apical portion of the valve, which forms about one-half its periphery. In all subsequent stages of growth, the deltidial plates are concealed, and whatever portion of the foramen appears thereafter above the dorsal valve is enclosed by the circumbonal tract. With the approach of maturity, this gradually disappears, and at full growth, every trace of it has become obliterated.

\author{
SpIRIFER CRISPUS, Hisinger, I 826 \\ Plate Vi, Figs. 6, 7 \\ Spirifer crispus, var. Simplex, Hall, 1879 \\ Plate Vi, Figs. 4, 5
}

Spirifer bicostatus, Vanuxem, i842, var. petilus, Hall, i 879

Plate Vi, Figs. I-3

Spirifera crispa, Hall. Twenty-eighth Ann. Rept. N. Y. State Mus. Nat. Hist., p. 157, pl. 24, figs. 6-12, 19. 1879 .

- - Hall. Eleventh Ann. Rept. State Geol. Indiana, p. 295, pl. 24, figs. 6-12, 19. 1882.

Spirifera crispa, var. simplex, Hall. Twenty-eighth Ann. Rept. N. Y. State Mus. Nat. Hist., p. I 57, pl. 24, figs. I-5. 1879 .

_- Hall. Eleventh Ann. Rept. State Geol. Indiana, p. 286, pl. 24, figs. I-5. I882. Spirifera bicostata? var. petila, Hall. Trans. Alb. Inst., vol. x, Abstract, p. I5. 1879.

_- Hall. Eleventh Ann. Rept. State Geol. Indiana, p. 297, pl. 27, figs. 8, 9. 1882.

The three forms which are here treated together, are closely allied in all their general characters. It is in their initial stages, however, that the 
resemblance becomes more than superficial, for, in young shells of less than $2 \mathrm{~mm}$. in length, it is difficult, and sometimes impossible, to refer them to any one of the three groups. A general expression of the common characters is furnished by the young of $S$. crispus, var. simplex, illustrated by figure 4 , on plate 6 .

Taking S. bicostatus, var. petilus as the simplest form, the young shell is found to be nearly circular in outline, with a single, broad, median fold on the dorsal valve. Passing to S. crispus, var. simplex, of the same size, the outline is seen to be broader, and there is an incipient plication on each side of the median fold. The outline is still broader in S. crispus, becoming decidedly subelliptical, and the two lateral plications on the dorsal valve are nearly equal in strength to the median fold. The surface ornamentation consists of fine spinulose, or granulose, concentric stria, differing very little in any of the three species.

In tracing the development of S. bicostatus, var. petilus, the shell is found to retain its embryonic characters up to full growth, neither materially changing its form, nor adding to the primitive number of plications. Likewise, S. crispus var. simplex changes very little except to increase in width and add a pair of plications at maturity. Individuals of S. crispus develop parallel to the variety simplex, up to a length of $5 \mathrm{~mm}$., or until about two-thirds the size of full-grown examples is attained. Subsequently, more plications are added, increasing the number from three or five to eleven, but otherwise, the general features of the shell are unchanged. Even the relative convexity of the valves remains the same at all periods.

In the incipient forms, the cardinal line extends for about one-fourth the width of the shell, and at maturity measures three-fourths of this width. The foramen does not develop at the same rate; at first, it occupies onehalf or one-third of the ventral area, but advancing growth gradually diminishes this ratio, until it is one-fourth or one-fifth the size of the hingearea. Two narrow, triangular, deltidial plates are present in full-grown 
individuals, but they do not serve to close the fissure which remains open in all stages of growth.

S. crispus, var. simplex reaches a width of $8 \mathrm{~mm}$., and $S$. crispus often measures $22 \mathrm{~mm}$. in width. Occasionally, a specimen of S. crispus of the usual size is found with but seven plications on the dorsal valve, suggesting a very large example of the variety, or that the characters of the smaller and simple form are sometimes continued far beyond the period when they usually disappear. Also, the features both of the species and variety may be combined in a single specimen, as one abnormal example has three plications on one side of the median fold and four on the other.

\section{Spirifer Radiatus, Sowerby, 1825 \\ Plate Vi, Figs. 9-II}

Spirifera radiata, Hall. Twenty-eighth Ann. Rept. N. Y. State Mus. Nat. Hist., p. 157, pl. 24, figs. 20-30. I 879 .

- - Hall. Eleventh Ann. Rept. State Geol. Indiana, p. 296, pl. 24, figs. 20-30. 1882.

The series of specimens representing the gradation in size from very young to mature forms is quite complete, but, unfortunately, the characters of the most interesting feature, the deltidium, are not well shown. The foramen is usually but partially closed when the shell reaches nearly its full dimensions, and at this period, the beak of the ventral valve is so incurved and thickened that the detailed development of the deltidial plates is obscured, and rendered difficult of interpretation.

This species has been so fully discussed in all its aspects, on account of its wide geographical distribution and varied physical conditions, that a diagnosis of the adult form is unnecessary in this place (vide plate 6, figs. I1, 11 $a)$.

Incipient Form (plate 6, figs. I0, IOa). The smallest example yet detected has a length of $1.5 \mathrm{~mm}$. The specimen is not well preserved, and the one used for illustration and description is somewhat larger, measuring 
$2 \mathrm{~mm}$. in length. The differences appear to be so slight that the characters of the larger may well be applied to the smaller individual.

The shell is nearly circular, flattened, and with the beaks not incurved, but directed outward. The area of the ventral valve is broad, triangular, open, and extends nearly the entire length of the cardinal line. The incipient dorsal fold and ventral sinus extend nearly to the beaks, and on each side there are about ten radiating strix. Radii are also present on the fold and in the sinus.

\section{DEVELOPMENTAL CHANGES}

The changes in the shell from advancing growth are principally the gradual widening of the valves, on account of the extension of the cardinal line and extremities, and the incurving of the beaks, from the progressive increase in the depth of the valves. From being circular in outline, the shell slowly widens until it is one-seventh wider than long. The ventral beak in old specimens is so arched over the area as to nearly conceal it, and prevent the opening of the valves to any extent. In the early stages, the depth of the conjoined valves is about half the length of the shell, while in obese mature forms, the depth is equal to the length.

The deltidial plates first appear as narrow elevated laminæ along the sides of the fissure under the ventral beak. A specimen about half-grown shows them as. represented in plate 6 , figure 9, consisting of triangular plates approximately as in figure $3^{\prime}$, of the following diagram. They are 'subsequently united along their inner margins, and rarely, in the material at hand, can any appearance of a foramen be discovered. In old shells, the growth and thickening of the deltidium makes it rugose, and it nearly closes the area.

From an examination of a number of-species of Spirifer showing considerable variety in the mode of development of the deltidium, we believe that there is no esssential difference, and that all intermediate conditions occur in this group, between the features represented in Spiriferina 
by Deslongchamps (see Summary), and the characteristic mode of development in Tercbratula and Rhynchonella. The genus Spirifer presents all these stages. In some species, the area is apparently closed by growth from the apex, and in others by the meeting of the deltidial plates at the base of the area and inclosing a foramen as in Rhynchonella. Spirifer niagarensis, S. perlamellosus, and S. cumberlandice are examples of the former mode, and $S$. sulcatus and approximately $S$. radiatus represent the latter. Both conditions are reached by accretion along the inner edges of the deltidial plates. The initial state is represented by a narrow elongate lamina on each side of the triangular area. Further growth produces a triangular plate ${ }_{2}$ and to the form of the triangle is due the apparent growth of the deltidium from the apex of the fissure downwards, or from the base of the fissure towards the beak of the ventral valve.

The accompanying diagrammatic outlines serve to illustrate the changes and the final results.

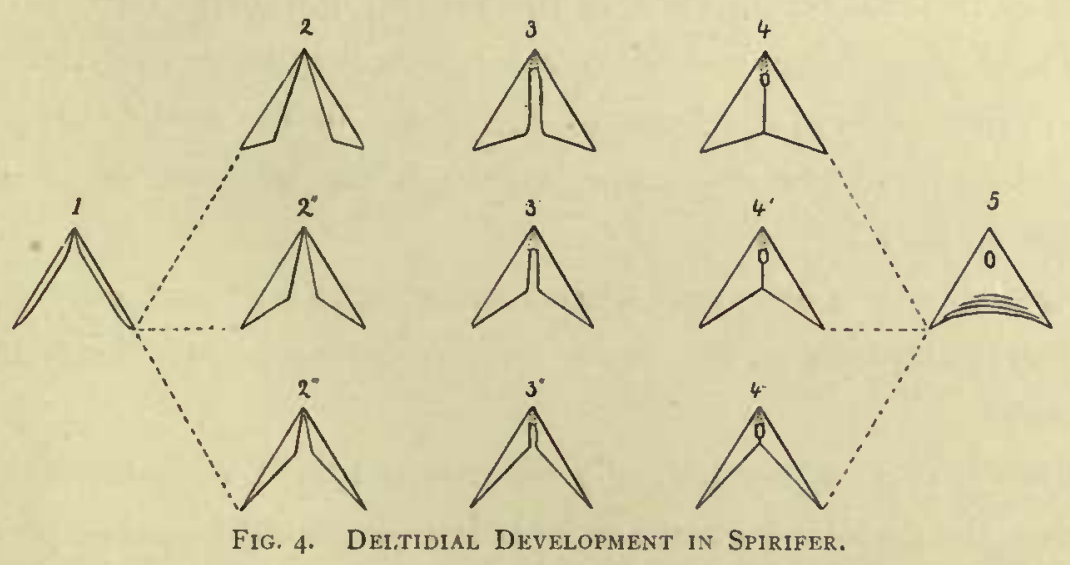

Figure 1 represents an area in an early stage of growth, with a narrow deltidial plate on each side, alike for each series.

Figure 2 shows scalene triangular plates, with the shortest side at the base of the area.

Figure $2^{\prime}$ shows plates with the two free edges more nearly equal. 
Figure 2 " presents narrow triangular plates as in figure 2, but with the shortest edges in the apex of the area.

In figures $3,3^{\prime}, 3^{\prime \prime}$, the growth has continued in the direction initiated in the preceding stage, and the apex of the area has been partially filled from the internal thickening of the beak.

Figures $4,4^{\prime}, 4^{\prime \prime}$ show the completed deltidium with the circular perforation. The plates in figure 4 nearly close the area, while in figure $4^{\prime \prime}$ the opening is nearly as high as wide. Further growth can now take place only along the lower free edges of the plates.

Figure 5 represents the results of subsequent growth and thickening, which have obliterated the evidences as to the mode of development, and unified all three cases. The position of the foramen below the apex of the area does not appear to be due to the approximation and union of the deltidial plates, but to the lowering of the actual cavity of the beak from the natural thickening of the shell, so that the foramen, as in other genera, is at the real termination of the ventral umbonal cavity.

It is seen that the manner of development is alike in each case, varying only from differences in the form of the plates in the earlier stages. The finished deltidium is also the same, although the methods of attaining the result differ in each.

Figures I, 2, 3, 4 are represented by S. sulcatus, ${ }^{*}$ and vary in no inportant particulars from the mode of development in Terebratula and Rhynchonella.

Figures $1,2^{\prime}, 3^{\prime}, 4^{\prime}$ are partially represented by S. radiatus, although, in this species, the circular foramen is usually obliterated by subsequent thickening and growth. (See figures 10, 9, 11, plate 6.)

Figures $1,2^{\prime \prime}, 3^{\prime \prime}$ are well shown in S. niagarensis (figure 8, plate 6), and the subsequent stages appear in mature forms of $S$. perlamellosus and $S$. cum-

* State of New York, Report of the State Geologist for the year 1882, published 1883, pl. 6o, figs. I, 2, 3 . 
berlandice. Other forms, notably those with elevated areas, such as $S$. macronotus, S. medialis, together with Cyrtina and Cyrtia, present considerable differences in the completed deltidium, due principally, it is believed, to the internal thickening of the beak and the growth of the transverse septum.

The deltidium of Spirifer thus appears to be the exact homologue of the same part in Terebratula, Rhynchonella, etc., and to be radically different from the so-called "pseudo-deltidium" of Strophomena, Strophodonta, Streptorhynchus, and allied genera, although this term has been currently applied to both the Spiriferidæ and the Strophomenidæ. 



\section{SUMMAR Y}

OF

\section{DEVELOPMENTAL CHANGES}

Size and Contour. Although the species described in the preceding pages present a wide variation in form and general appearance, the nature of the changes which take place in the development of the shell is remarkable in its uniformity.

In nearly every species, the inceptive state is represented by a shell having a subcircular outline, with valves of slight convexity. This phase usually disappears before the individual reaches a length of $\mathrm{I} \mathrm{mm}$., after which the specific characters are assumed, and are progressively emphasized with each succeeding increment.

On comparing the incipient stage in these fossil shells with that of recent brachiopods, as given by Mr. E. S. Morse for Terebratulina, and by Mr. W. K. Brooks for Glottidia, we find that, in respect to actual size, there is a slight, though perhaps unessential difference. At the earliest stage of growth figured by Morse,* the shell has a length of about $.3 \mathrm{~mm}$. and in the next stage represented, of approximately $.6 \mathrm{~mm}$.

* Memoirs of the Boston Society of Natural History, Vol. ii; On the Early Stages of Terebratulina septentrionalis, pl. I, figs. 2, 3. 1869. 
The first two stages of the shell figured by Mr. Brooks* represent free animals, and measure .24 and $.3 \mathrm{~mm}$. in length, respectively. The shell became attached by the pedicle only upon attaining a length of $2.5 \mathrm{~mm}$.

Most of the fossil forms have furnished evidence, either from actual elemental specimens or from the apical portions of subsequent incipient stages, that the true initial shell did not reach a size of more than $.5 \mathrm{~mm}$. in length. Soon after this period, the characters of each species become developed and impressed upon the shell more or less gradually.

Even such distinct groups as Rhynchonella, Spirifer, Athyris, Rhynchotreta, Anastrophia, Nucleospira, and the Meristoids, in their initial stages, approach one another so closely that they can be determined only from comparatively trivial features. They are alike in form, contour, convexity, beaks, and cardinal area, and the only marked differences are to be found in the faint indications of plications, strix, folds, and sinuses. For species of some genera, as Orthis, Whitficldia, and Spirifer, even these characters are not determinative, and it is impossible to refer certain embryos to their proper place.

From the foregoing statements, it would naturally be inferred, that the species which, at maturity, present characters abnormal to the typical structure, have been diverted from the harmony which existed in the incipient stages, with the other members of the group. This has been shown to be the case in all the reversed species above examined, belong. ing to the genera Anastrophia, Strophonella, and Streptis.

Beginning with the initial shell having a circular outline and depressed valves, we find that subsequent growth takes place about the periphery, and in the majority of species, the convexity is gradually increased until maturity is reached. This assertion does not hold true

* Johns Hopkins University; Chesapeake Zoölogical Laboratory. The Development of Lingula and the Systematic Position of the Brachiopoda, plates 1 and 2. 1879. 
for such forms as the Strophomenidæ, which vary in convexity, either very slowly or not at all, up to individuals about half-grown, when the valves become more or less deflected and often concave. Such a reversion in the shell is in conformity with the degeneracy which is traced in the development of the cardinal area and pedicle-sheath, mentioned on a subsequent page.

The observations of Brooks and Morse, in the works just cited, show, that in both the hingeless and the hinged brachiopods, as represented by Lingula and Terebratulina, the early stages of the shell approach a subcircular outline, and BRoOKs remarks (op. cit. p. 43), that "the recent and fossil shells of the various species of Crania, Lingula, Lingulella and Obolus, and other hingeless Brachiopods, furnish a series of adult forms representing all the changes through which the outline of Lingula pyramidata passes during its development."

In these respects, then, uniformity is established in the embryology of the ancient Silurian types and their modern descendants.

VAlves. The dorsal valve in young shells is smaller than the opposite, and usually more depressed. These relations, as a rule, are continued up to adult size, except that the ventral valve often increases more rapidly in convexity, producing a consequent incurving of the beak over the cardinal area, as in Orthis and Rhynchonella indianensis. Some species present both beaks as incurved, a condition well represented in Whitfieldia maria, Eichwaldia reticulata, Rhynchonella acinus, and $R$. neglecta. In Anastrophia, the comparative relations of the valves become reversed from their initial condition, on account of the more rapid increase in the depth of the dorsal valve, so that, at maturity, the dorsal beak is much incurved, and often the umbo extends beyond that of the other valve, although the beaks preserve their normal condition of superposition.

Several of the species show an embryonal sinus in the dorsal valve, 
with a corresponding fold in the ventral, beginning soon after the initial stage of the shell has been passed, and disappearing before the shell is half-grown. Those forms presenting this feature to a marked degree are Rhynchotreta cuncata, Rhynchonella whitii, $R$. indianensis, R. neglecta, $R$. acinus, Atrypa reticularis, and Retzia sobrina. In Rhynchotreta cuneata and Atrypa reticularis (plate 4, figs. I $2-15$, and plate 6, figs. I2-14), we have shown the gradual inception of this sinus, its maximum development and obsolescence, and, finally, its reversion into a fold which thereafter persists and usually increases in prominence in all the succeeding stages of growth. The embryonal sinus is not present in Spirifer, Anastrophia, Eichwaldia, Whitfueldia, Meristina, Orthis, nor in the Strophomenidx. Such of these as show a dorsal fold or ventral sinus, have them developed early in the growth of the shell, and they. usually increase regularly to the time when the full size of the shell is attained.

BEAKs. The beak of the ventral valve in its earliest condition is commonly erect, pointed outwards, and of a broad triangular form, while that of the dorsal valve is small, not prominent, and lies in the longitudinal axis of the shell. In all cases, the subsequent deepening of the valves tends to incurve the beaks toward the cardinal area. The degree of incurvature varies greatly in the different species. Meristclla rectirostra shows a minimum, and Whitfeldia maria or Atrypa reticularis, a maximum, and between these limits all intermediate conditions occur. The usual degree of incurvature is presented in Spirifer radiatus, Retzia evax, and the Rhynchonellidæ.

The outlines on plate 4 , illustrating the profiles of the beaks in a series of Rhynchotreta cuneata, represent an uncommon condition, for in this species, the ventral beak, from its divergent initial position, gradually approaches, and at maturity attains parallelism with the longitudinal axis of the shell. It never becomes sufficiently incurved to conceal, to the slightest degree, the deltidial area, while the initial dorsal beak becomes more 
and more incurved, until, finally, it lies entirely within the ventral umbonal cavity.

Those species furnished with a circular apical perforation, as Atrypa reticularis, Retsia evax, and Rhynchotrcta cuncata, lose the initial point of the ventral beak from absorption, due to the increase in the size of the perforation or to its final terminal position. In Atrypa reticularis, or Whitficldia maria even both beak and perforation are destroyed, from the forcing of the ventral beak into contact with the dorsal umbo, produced by the great increase in the depth of the valves from growth along their anterior margins.

Cardinal area. Omitting for the present the Strophomenidx and Orthidæ, the initial state of the ventral cardinal area for all other forms is a broad triangular opening beneath the beak, with simple sharp margins. This condition is never passed by Meristella rectirostra, which shows a uniform, open, triangular area in every period of growth.

A farther advanced state of progress initiates the deltidial plates, which first appear as narrow laminæ along the sides of the area. The areal development of Spirifer crispus, Rhynchonella neglecta, and $R$. acinus, ceases at this point.

.In the next stadium, the further growth of the deltidial plates along their free edges gives them a triangular form, and they tend to narrow the limits of the opening and define the peduncular foramen. Spirifer niagarensis and Rhynchonella whitii represent species which are arrested at this period.

The completed growth shows the deltidial plates uniting by symphysis along a median line, and inclosing near the apex of the area a more or less circular pedicle-perforation. Rhynchotreta cuneata, Whitficldia maria, Rctzia evax, etc., after passing through all the earlier conditions, reach this limit of development.

The results of senile and extravagant growth often obliterate or de- 
generate the normal deltidial advancement, the plates becoming thickened and their features obscured, while in some species processes are given off, as in a number of the Mesozoic Rhynchonellidæ.

The cardinal area of the Strophomenida in its early phase shows a small pedicle-sheath for the ventral valve and a narrow grooved process under the beak of the dorsal. The perforation for the passage of the peduncle does not materially increase in size with the growth of the shell and often is obliterated, while the dorsal callosity usually reaches a considerable development.

Additional evidence of the degeneracy of the pedicle is afforded by many species of other genera, which have a calcareous attachment.to foreign objects at the apex of the ventral valve, the pedicle, therefore, becoming functionally obsolete.

Observations having some analogy with the facts here presented have been made, in a very restricted sense and usually incidentally, by various authors. Our own results, though derived from the species of a single fauna, must not be given too limited an application, for they involve nearly every important family of paleozoic articulate brachiopods, and we may tentatively assume that, as a rule, the essential features of variation observed in any member of a genus will hold good of the other members. In regard to the development of the characters of the pedicle-passage, $i . c$. the deltidial plates and the foramen, there is good reason to regard the process as substantially identical in all the genera represented, making the necessary allowance for the peculiar variation seen in the Strophomenidæ, which may not, however, prove it an exception to the general statement.

The various terms which have sometimes been applied to the condition of the deltidium in the rostrate genera, as deltidium amplectens, when the foramen is entirely surrounded by the plates, as in various Mesozoic Rhynchonellæ (but in no paleozoic species of which we are aware), deltidium sectans, when the plates bound the foramen only on the lower side, the upper 
side encroaching on the substance of the umbo, as in Terebratula, Meristina, etc., deltidium discretum, when the plates do not come into contact, as in Terebratella, some species of Rhynchonella, etc., must be regarded as having no further significance than to express the existing condition of the foramen and deltidium in any given spetimen, that is, as indicating a stage of development, not necessarily a generic or even specific character.

The observations of M. Eugrene Deslongchamps upon these features are of much value, and in most respects, as far as carried out upon related forms, are in harmony with our own (Note sur le développement du deltidium chez les brachiopodes articulés: Bull. Soc. Géol. France, $2^{\mathrm{e}}$ Ser. T. xix, pp. 409-413, pl. ix, I862), but with his conclusions, we are forced to differ in some respects. The investigations referred to were made upon one (or more) Mesozoic species of Terebratula, Rhynchonella, and Spiriferina, specific designations not given. The illustrations of Terebratula (figs. $\mathrm{I} a, b, c$, and column A, $\alpha, \beta, \gamma, \delta)$ show in effect the characters seen in Meristina nitida, Whitficldia maria, and others; those of Rhynchonella early stages of similar character, resulting in a deltidium amplectens, such, as just observed, we have failed to discover in paleozoic Rhynchonellæ.

In Spiriferina, according to the author, the deltidium is produced by the gradual development of a single plate in the apex of the triangular opening, increasing downward with age, a very distinct mode of formation from all the others, and open to verification in the species described by $M$. Desiongchamps, as his figures make no allowance for a pedicle-sinus or perforation, a feature, though not of frequent occurrence in the Spiriferidæ, yet one necessary to account for.

We have examined specimens of Spiriferina pinguis, Deslongchamps, $S$. rostrata, Schlotheim, and $S$. vualcotti, Sowerby, and find that these species, at least, develop triangular deltidial plates. Those in Spiriferina pinguis and $S$. walcotti are comparable with the same parts in Spirifor perlamcllosus and $S$. cumberlandice, and their form and mode of growth 
are expressed by the outlines $2^{\prime \prime}, 3^{\prime \prime}$, on page 79 , and is further shown in the accompanying illustration. Additional growth causes the plates to unite along the median line, obliterating the partially formed pedicle-perforation, and subsequent increment can naturally only take place along their lower free edges.

Our remarks on Spirifer radiatus and $S$. crispus indicate that the development of the

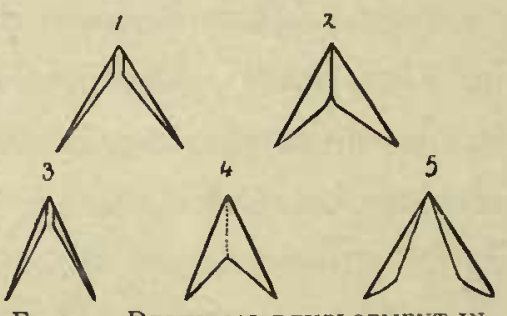

Fig. 4. Deltidial development in r, 2. Spiriferina pinguis, Desl. 3.4. Spiriferina walcotti, Sow. 5. Spiriferina rostrata, Schl. plates in this member of the same family is quite in harmony with the process as seen in the rostrate forms generally.

The following is the summarization of DesLongChaMps's conclusions as given by himself :

(r) The deltidium is one of the most important features in the articulated brachiopods.

(2) As far as Jurassic species are concerned, the deltidium may suffice to characterize the families.

(3) In the various stages of development of this part, the aspect of the shell is entirely changed.

(4) The deltidium appears under three important modifications: A. development below the peduncular arm, characterizing the Terebratulidæ, C. development above the peduncle, Spiriferidæ, B. mixed development, surrounding the peduncle, Rhynchonellidæ.

(5) The stage at which the development is arrested or the exuberance of development may suffice to characterize sections under the families.

It has just been shown that conclusions 2,4 , and 5 are not capable of the extended application which he has given them.

A preceding remark, that the course of development of the deltidial characters throughout the genera here discussed, may be considered as fundamentally uniform, calls for explanation in its application to Orthis and 
the Strophomenidæ. In the latter forms, we have seen that the remarkable development of the pedicle-sheath is primary, and is invariably more or less atrophied with age, and probably functionally inactive at maturity. Hence the retention of this sheath in any species at maturity is the perdurance of what must serve as an embryonic character within the limits of this family. It cannot escape observation that the pedicle-sheath is in analogy with the entire rostrate umbo of the ventral valve in the Rhynchonellæ, Terebratulæ, etc., as a specialized extension of the valve for the protrusion of the pedicle (compare the extreme development of the umbo in the genus Terebrirostra). That these parts are also homologues, it is difficult to prove, on account of the pedicle-sheath becoming more degenerate as maturity approaches, but, assuming this homology, we may regard the sheath and its gradual disappearance, as an indication of degeneracy in the family, the presence of the sheath pointing toward a derivation from the rostrate type.

The atrophy of an organ so highly specialized as the sheath, is, aside from any consideration of relationship to other groups of the brachiopods, itself confirmatory of such degeneracy. Furthermore, it will be noticed, that there is, throughout these Strophomenoids, an inclination, as mature growth comes on, toward the simple triangular pedicle-apertures in Orthis. The disappearance of the pedicle-sheath leaves the aperture of the ventral valve essentially free, as seen in Strophomena rhomboidalis and Streptorhynchus subplanum, while the aperture of the dorsal valve is filling pari passu with a callosity. In other words, the structure of these parts. is actually degenerating toward maturity, to that of Orthis, which is the simplest, least differentiated condition among the articulated brachiopods, and serves to fortify the position of the genus at the base of the entire series. In Orthis, the pedicle-apertures on both valves are of the same size in early growth, and have undoubtedly acted together as a single opening, through which the fleshy arm was protruded as much on one side as the other, a fact indicative of an extreme lack of differentiation in the two valves in the articu- 
late species, but agreeing closely with some of the inarticulate genera, $c . g$. Lingula, Leptobolus, Obolus. The specialization which accompanies subsequent growth confines the pedicle more closely to the ventral aperture, and, as a result, the dorsal aperture is gradually filled by a callosity. Thus, also, the Strophomenidæ; but Streptorhynchus subplanum shows at maturity what has not yet appeared in Orthis, viz., the initiation of deltidial plates, in conformity with the general course of development of the cardinal features observed in other families.

It is not well in this place to go beyond the scope of this work, and the species of Strophomenidx here discussed for facts confirmatory of our observations. It may be remarked, that the stage at which the development of the deltidial features has been arrested at maturity in this family varies with the species, not with the genus. When every trace of these features is obliterated, as is usual in Strophodonta, a slight abrasion of the apical substance of the shell will often show a trace of the obsolete pedicle-tube. At times, in the same genus, this is retained at maturity as an external feature, and in such a case is usually accompanied by some indication of the subapical sheath. In both Strophodonta and Strcptorhynchus (especially of the later paleozoic faunas), the cavity of the pediclesheath, if it be retained in any form, at maturity, has been filled by the deposition of calcareous matter about the compound cardinal processes of the opposite valve, and thus wholly diverted from its original function.

In conclusion, it is to be observed, that of recent species of brachiopods a very great number show an incomplete development of the deltidial plates at maturity. Such is Rhynchonclla to a large degree; also Cistella, Argiope, Kraussina, Terebratclla, and Magasella; and we may assume the structural degeneracy which is thus indicated, to be the natural concomitant of the secular decline of the entire class.

It is not improbable that from an early form related to the genus Orthis, phylogenetic development tended in two main channels. One 
leading through Strophomena, Scenidium, Orthisina, Leptana, Chonetes, Productus, and Strophalosia, and the other in the direction of Rhynchonella, Spirifer, Atrypa, Retzia, and Terebratula.

Internal. Apparatus. Our observations upon the development of the brachial supports are limited to the species Retzia evax. Here it is found that the number of revolutions of the spiral ribbon increases with age, but we are not prepared to say what the inceptive condition of this apparatus may have been. In the early stage represented on page 60, where the ribbon has completed two revolutions, the supports must have been exceedingly tenuous and delicate, for they can be traced in the crystalline or muddy filling of the shell, only by extremely faint lines, composed of minute dots of pyrite. As observed under the discussion of these features, the character or actual existence of the loop connecting the spirals was not established, but it is developed, with all normal characters, in a shell $4 \mathrm{~mm}$. in length, where the ribbon makes four revolutions.

It has been shown by MORse, ${ }^{*}$ that in Terebratulina septentrionalis, the loop (i. e. the entire brachial support) begins by the development of two acute processes from the lower moiety of the dental plate, which assume the character of crura, eventually meeting and coalescing on the dorsal side, forming the completed loop at an early stage, the ventral horns of the loop never uniting. The simple nature of the support in these shells precludes the possibility of the continued growth which obtains in the more complicated apparatus of the spiriferous species. The inception of the brachial support was observed by Morse in an individual $\mathrm{I} \mathrm{mm}$. in length, but the lateral processes are not conspicuously developed until a length of $3 \mathrm{~mm}$. is attained, and they have not united at a length of $4 \mathrm{~mm}$. It is therefore possible, from these data, that Retzia evax does not have the loop completed at so early an age as that indicated by a length of $2.5 \mathrm{~mm}$.

* Memoirs of the Boston Society of Natural History, Vol. ii ; On the Early Stages of Terebratulina septentrionalis, pl. 2 , figs $48-55$. 1869 . 
The observations by Monse are corroborated by those of DALL* on Terebratula cubensis.

Surface Ornaments. Nearly all the observations upon initial shells or upon that portion situated at the apex of the beak of more advanced stages and representing the initial shell, seem to warrant the assertion that the surface ornaments do not appear until the second or a later period is reached in the development of the shell.

For the plicate species, nearly the full number of plications appear simultaneously, as in Rhynchonella indianensis, $R$. acinus, and Rhynchotreta cmeneata, or they are introduced in pairs, as upon Rhynchonella whitii, ? R. neglecta, and Retzia sobrina.

The strix of Strophomena rhomboidalis are developed to the full capacity of the marginal area as soon as the first growth-line is completed. The number is increased in three distinct manners, (a) by division, (b) by intercalation, and (c) by addition at the cardinal angles. Some species present all three of these, while others add to their strix or plications by any one or two of the modes.

The concentric ornamentation in such species as Spirifer crispus and Streptorhynchus subplanum appears early in the growth of the embryo, and continues to be repeated without variation, except in Strophomena rhomboidalis and allied forms, which develop, during the last stage of growth, a geniculated curtain without concentric undulations.

Varieties and AbNormalities. Varieties usually begin to express themselves early in the development of the shell, and the divergence from the normal form rapidly increases as maturity approaches. Several of the species represented by abundant material, are readily separable into three distinct groups of 'forms, (a) long form, (b) normal form, and (c) broad form. The history of each may be clearly traced, and they

* Proceedings of the Academy of Natural Sciences of Philadelphia, 1877, pt. ii ; Report on the Brachiopoda of Alaska and the adjacent Shores of North-west America, p. I 55. 
usually are found to unite with the line of the normal form (b), several removes from the initial member of the series. Sometimes the varieties do not reach the adult dimensions of the normal shell and may be considered as varietal dwarfs.

The representation of varietal and of certain abnormal conditions by complete series of fossil specimens shows, that in these directions, there was a distinct developmental tendency, or genetic impulse, independent of normal growth.

Senility is always expressed by the thickening of the shell which takes place after the individual reaches adult size. The thickening may involve the whole interior of the valves, producing a truncate appearance at the margins, or it may take place by frequent interrupted growth along the margins, giving to this portion a varicose aspect. As a result of this senile growth. the vertical diameter of the shell is increased, and the beaks involuted, so that they are often so closely appressed as to conceal the cardinal area and truncate the ventral beak, and in addition, the margins of the valves lose the characteristic ornamentation of the species and correspond to the clinologic and nostologic stages as defined by Mr. Нyatт.*

Abnormalities frequently find an explanation in some pathological or accidental conditions which become instituted at any period in the life of the animal, and leave their impress on the shell. The functional failure of a developing organ may cause the parts to revert to an embryonal type, and although it is difficult to apply this statement to the shelly covering of the animal, yet this condition is sometimes found. The specimen of Rhynchonella ncglecta described on page 37 is an instance of this kind. Another abnormal variation is noticed in certain individuals which preserve the larval features of the shell long after it has passed the early stages, and when, in many cases, it has reached the full adult dimensions.

* Proceedings of the Boston Society of Natural History, Vol. xxiii, 1888; Values in Classification of the Stages of Growth and Decline, with propositions for a New Nomenclature. 



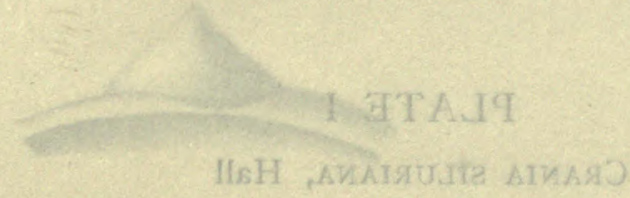

$$
\text { ciogis }
$$

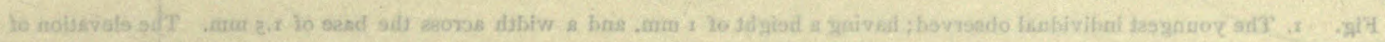

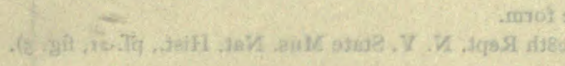

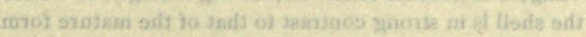

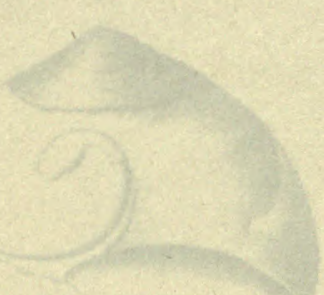

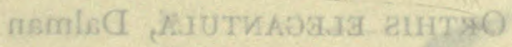

$$
\text { Ex } \log _{6} 9
$$

hitis stat os?

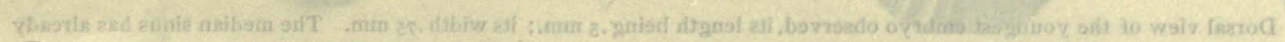

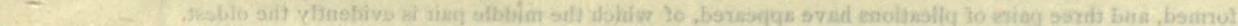

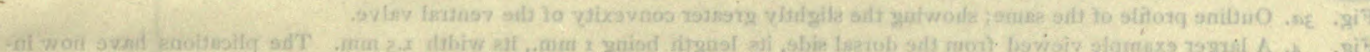

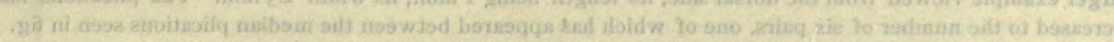

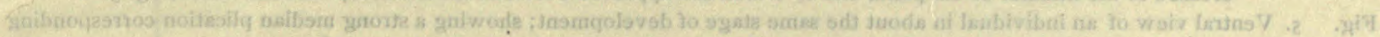

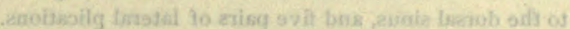

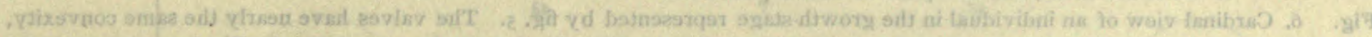

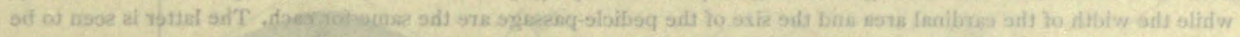

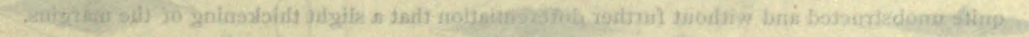

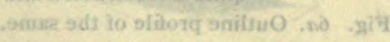

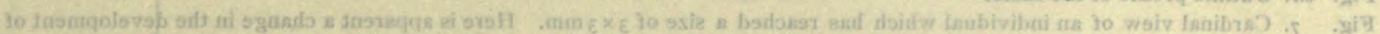

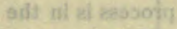

\section{EXPLANATION OF PLATE I}

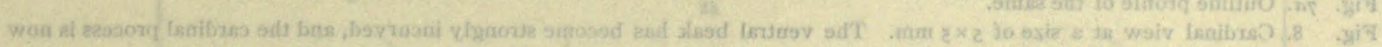

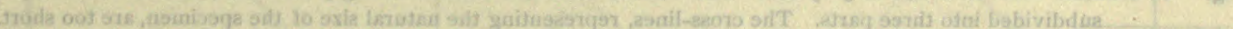

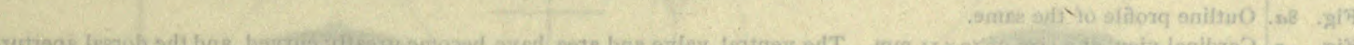

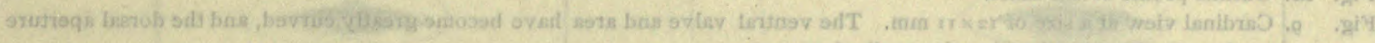

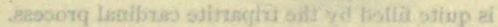

sctue gifs th slitosg smibuo, se . ath

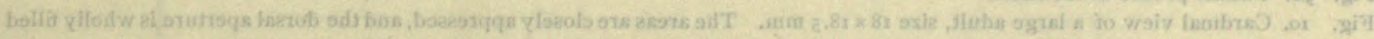

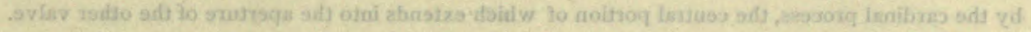
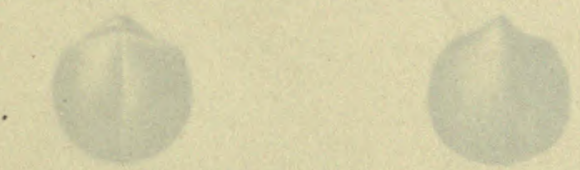

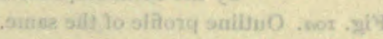

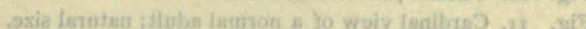

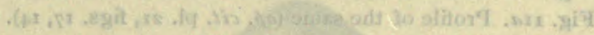

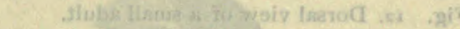

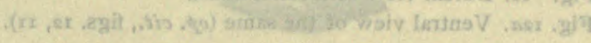

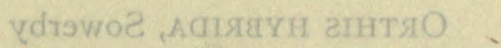

5x 29yis

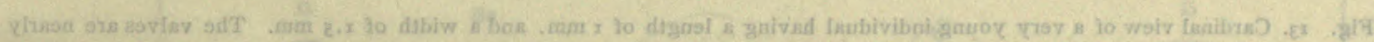

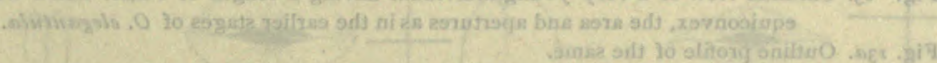

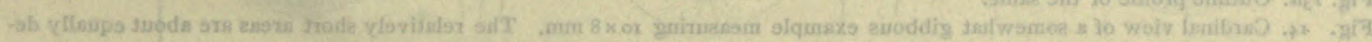

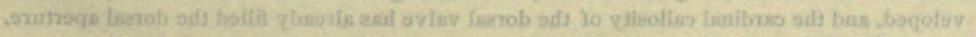

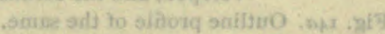

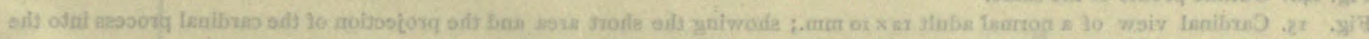

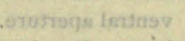

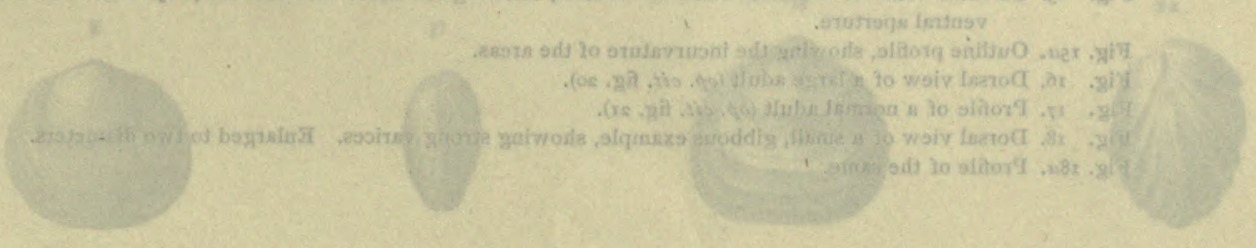




\section{PLATE I \\ Crania siluriana, Hall \\ Page $x_{3}$}

Fig. I. The youngest individual observed; having a height of $\mathrm{xmm}$, and a width across the base of $\times .5 \mathrm{~mm}$. The elevation of the shell is in strong contrast to that of the mature form.

Fig. 2. A mature individual attached to a shell of Platystoma (28th Rept. N. Y. State Mus. Nat. Hist., pl, 2r, fig. 5).

\section{Orthis elegantula, Dalman}

Page ${ }_{3}$

See Plate vii

Fig. 3. Dorsal vlew of the youngest embryo observed, its length bcing. 5 mm.; its width.75 mm. The mediaa sinus has already formed, and three pairs of plications have appeared, of which the middle pair is evidently the oldest.

Fig. $3 a$. Ontline profile of the same; showing the slightly greater convexity of the ventral valve.

Fig. 4. A larger example viewed from the dorsal side, its leogth being 1 mm., its width $\mathbf{r} .5 \mathrm{~mm}$. The plications have oow in. creased to the number of six pairs, one of which has appeared between the median plications seen in fig. 3

Fig. 5. Ventral view of an individual in abont the same stage of development; showing a strong median plication corresponding to the dorsal sisus, and five pairs of lateral plicatioos.

Fig. 6. Cardinal view of an individual in the growth-stage represented by fig. 5. The valves have nearly the same convexity, while the width of the cardinal area and the size of the pedicle-passage are the same for each. The latter is seen to be quite unobstructed and without further differentiation that a slight thickening of the margins.

Fig. 6a. Outline profile of the same.

Fig. 7. Cardinal view of an individual which has reached a size of $3 \times 3 \mathrm{~mm}$. Here is apparent a change in the development of the cardinal area and foramen of the valves. The primary indication of the callosity or cardinal process is in the apex of the dorsal opening. The difference in the convexity of the ralres has also noticeably increased.

Fig. 7\%. Outline profile of the same.

Fig. 8. Cardinal view at a size of $5 \times 5 \mathrm{~mm}$. The ventral beak has become strongly incurved, and the cardinal process is now subdivided into three parts. The cross-lines, representing the natural size of the specimen, are too short.

Fig. $8 a$. Outline profile of the same.

Fig. 9. Cardinal view at a size of $12 \times 1 \mathrm{~mm}$. The ventral valve and area have become greatly curved, and the dorsal aperture is quite filled by the tripartite cardinal process.

Fig. $9 a$. Outline profile of the same.

Fig. ro. Cardinal view of a large adult, size $18 \times 18.5 \mathrm{~mm}$. The areas are closely appressed, and the dorsal aperture is wholly filled by the cardinal process, the ceatral portion of which extends into the aperture of the other valve.

Fig. Ior. Outline profile of the same.

Fig. Ir. Cardinal view of a normal adult; natural size.

Flg. r1a. Profile of the same (op. cit. pl, 2x, figs. 17, 14).

Fig. 32. Dorsal view of a small adult.

Fig. r2a. Ventral view of the same $(o p$, cit., figs. 12, II $)$

\section{ORTHIS HYBRIDA, Sowerby}

Page 17

Fig. 13. Cardinal view of a rery youjg individual having a length of $1 \mathrm{~mm}$. and a width of $\mathbf{r . 5} \mathrm{mm}$. The valves are nearly equiconvex, the area and apertures as in the earlier stages of 0 . elegantula.

Fig. r3a. Outline profile of the same.

Fig. 14. Cardinal view of a somewhat gibbous example measuring $10 \times 8 \mathrm{~mm}$. The relatively short areas are about equally devcloped, and the cardinal callosity of the dorsal valve has already filled the dorsal aperture.

Fig. r\&a. Outline profile of the same.

Fig. 15. Cardinal view of a normal adult $12 \times$ so mm.; showing the short area and the projection of the cardinal process into the ventral aperture.

Fig. r5a. Ontline profile, showing the incurvature of the areas.

Fig. 16. Dorsal view of a large adult (op. cit. fig. 20).

Fig. 17. Profile of a normal adult (op. cit, fig. 2r).

Fig. I8. Dorsal view of a small, gibbous example, showing strong varices. Enlarged to two diameters.

Fig. $18 a$. Profile of the same. 

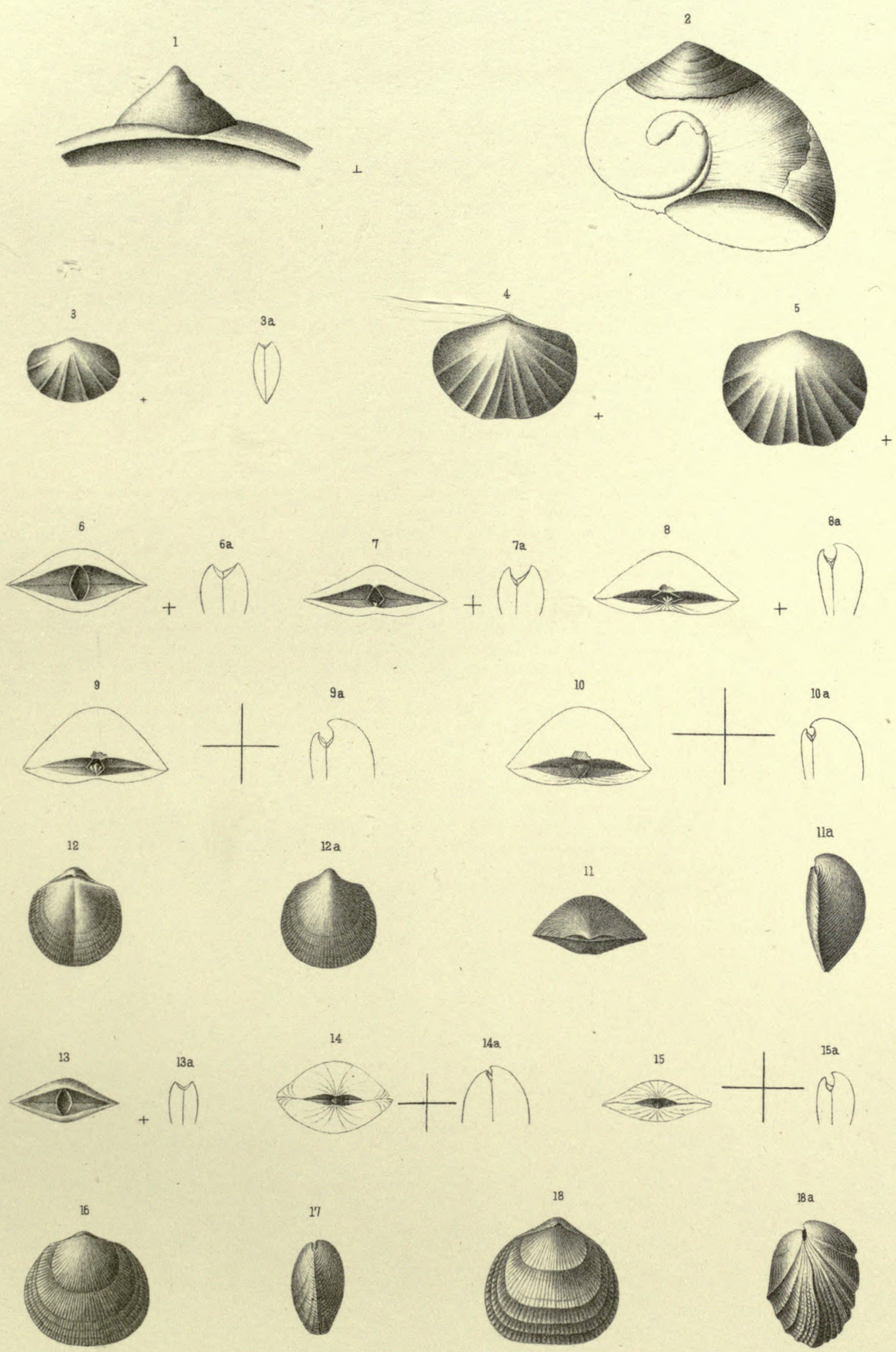

Philip Ast, lith. 



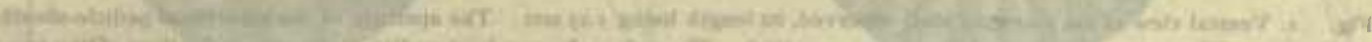

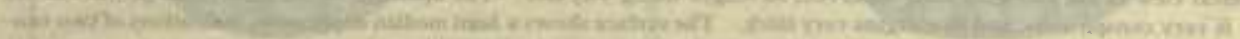

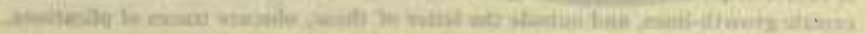

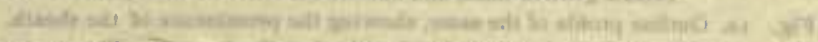

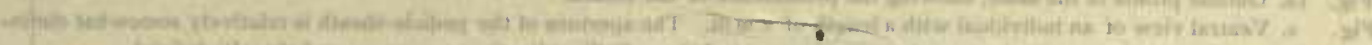

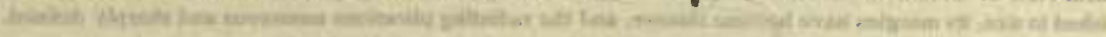

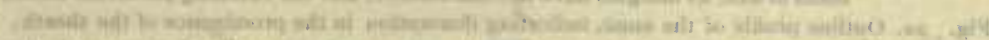

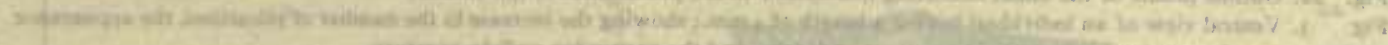

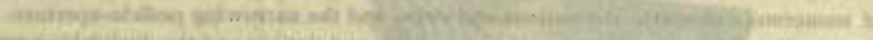

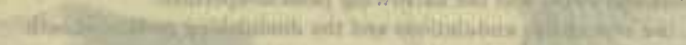

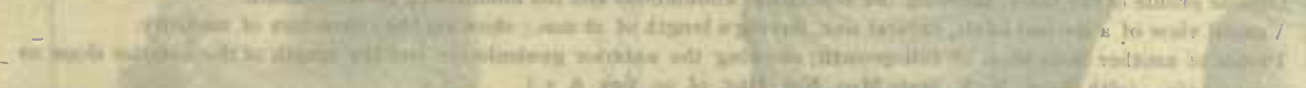

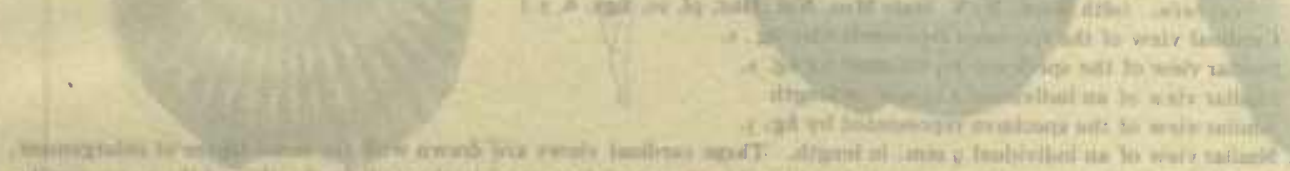

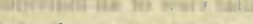

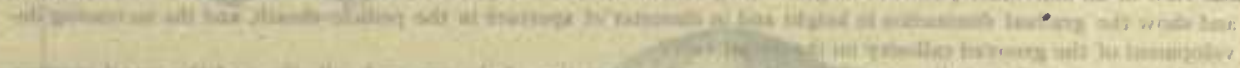

\section{EXPLANATION OF PLATE II}

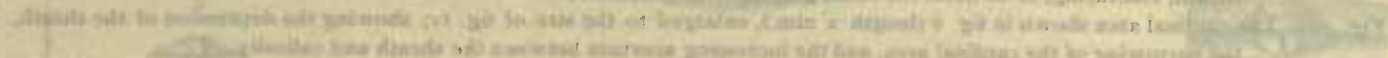

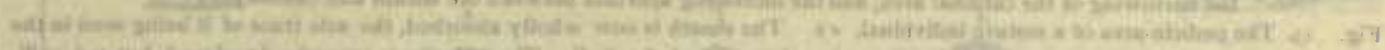

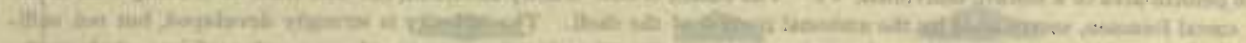

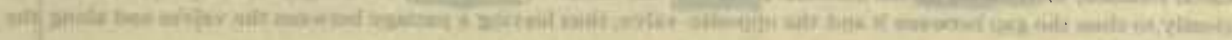

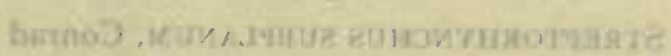
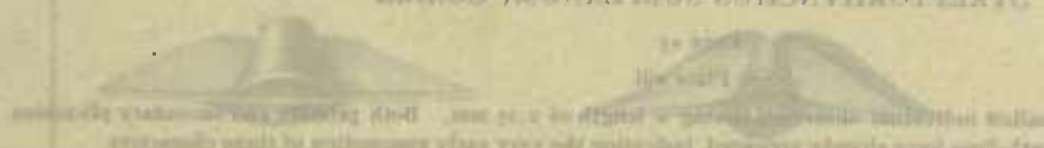

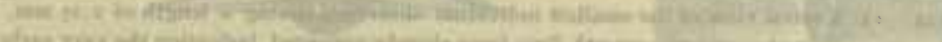

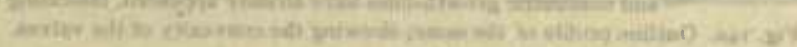

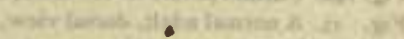

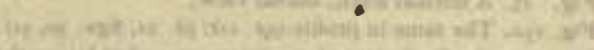

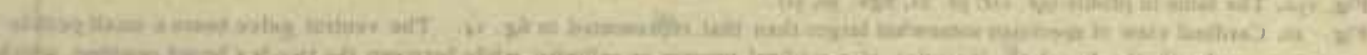

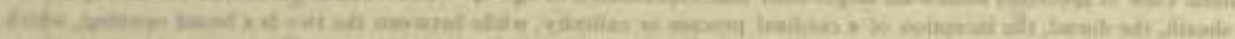

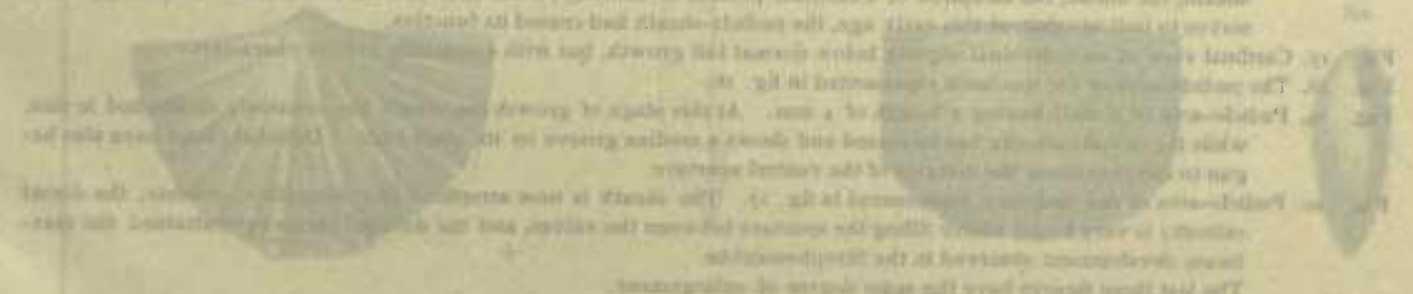

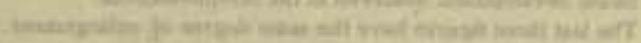
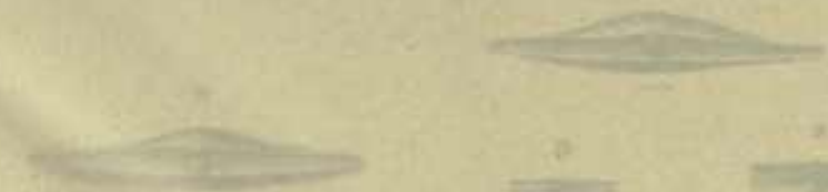


\section{PLATE II}

\section{STROPHOMENA RHOMBOIDALIS, Wilckens}

Page 18

Fig. I. Ventral view of the youngest shell observed, its length being $1.25 \mathrm{~mm}$. The aperturc of the cmbryonal pedicle-sheath Is very conspicuous, and its margins very thick. The surface shows a faint median depression, indications of two concentric growth-lines, and outside the latter of these, obscure traces of plications.

Fig. $x a$. Outline protile of the same, showing the prominence of the sheath.

Fig. 2. Ventral view of an individual with a length of $2 \mathrm{~mm}$. The aperture of the pedicle-sheath is relatirely somewhat diminished in size, its margins have become thinner, and the radiating plications numerous and sharply defined.

Fig. 2a. Ontline profilc of the same, indicating diminution in the prominence of the sheath.

Fig. 3. Ventral view of an individual having a length of $4 \mathrm{~mm}$; ; showing the increase ia the number of plications, the appearance of numerous concentric undulations and strix, and the narrowing pedicle-aperture.

Fig. $3 a$. Outline profile of the same, showing the concentric undulations and the diminishing pedicle-sheath.

Fig. 4. Ventral view of a normal aduit, natural size, having a length of $28 \mathrm{~mm}_{-}$; showing the characters of naturity,

Fig. 4a. Profile of another individual of full-growth; showing the anterior geniculation and the length of the anterior slope or curtain. (28th Rept. N. Y. State Mus. Nat. Hist. pl, 22, figs, 6, 7.)

Fig. 5. Cardinal view of the specimen represented by fig. $x$

Fig. 6. Similar view of the specimen represented by fig. 2.

Fig. 7. Similar view of an individual $2.65 \mathrm{~mm}$. in leagth

lig. 8. Similar vicw of the specimen represented by fig. 3 .

Fig. 9. Similar view of an individual $9 \mathrm{~mm}$. in length. These cardinal views are drawn with the same degree of enlargenent, and show the gratual diminution in height and in diameter of aperture in the pedicle-slieath, and the increasing development of the grooved callosity on the dorsal valve.

Fig. so. Cardinal view of a normal adult, natural size; showiog the great size of the grooved callosity, and the caecal opening representing the atrophied pcdicle-sheath (op. cit. fig. ro).

Fig. 11. The cardinal area represented in fig. 5 (length 1.25 mm.), still further enlargerl; showing the broad, prominent, exsert sheath, embracing, at its base, the faint, grooved dorsal callosity.

Fig. 12. The cardinal area shown in fig. 6 (length $2^{4} \mathrm{~mm}$.), enlarged to the size of fig. II; showing the depression of the sheath, the narrowing of the cardinal area, and the increasiog aperture between the sheath and callosity.

Fig. I3. The pedicle-area of a inature individual, $\times 2$. The sheath is now wholly absorbed, the sole trace of it being seen in the creal foramen, surrounded by the umbonal portion of the shell. The callosity is strongly developed, but not sufticiently to close the gap between it and the opposite valve, thus leaving a passage between the valves and along the dorsal groove.

\section{STREPTORHYNCHUS SUBPLANUM, Conrad}

Page 23

Sec Plate viii

Fig. 14. Ventral view of the smallest individual observed, having a length of $2.25 \mathrm{~mm}$. Both primary and secondary plications and concentric growth-lines bave already appeared, indicating the very early assumption of these characters

Fig. I $4 a$. Outline profile of the same; showing the convexity of the valves.

Fig. 15. A normal adult, dorsal view.

Fig. ${ }_{5} a$. The same in profile (op. cit. pl. 21, figs. $30,3^{\mathrm{I}}$ ).

Fig. r6. Cardinal view of specimen somewhat larger than that represented in fig. 14 . The ventral valce bears a small pediclesheath, the dorsal, the inception of a cardinal process or callosity, while between the two is a broad opening, which scrves to indicate that, at this carly age, the pedicle-sheath had ceased its function.

Fig. 17. Cardinal view of an individual slightly below normal full growth, but with essentially mature characters.

Fig. 18. The pedicle-area of the specimen represented in fig. 16.

Fig. rg. Pedicle-area of a shell having a length of $4 \mathrm{~mm}$. At this stage of growth the sheath has relatively dininished in size, while the dorsal callosity has increased and shows a median groove on its inner edge. Deltidial plates have also begun to develop along the margins of the ventral aperture.

Fig. 20. Pedicle-area of the specimen represented in $6 \mathrm{~g} . \mathrm{x}^{7}$. The sheath is now atrophied and altogether obsolete, the dorsal callosit $y$ is very large, nearly filling the aperture between the valves, and the deltidial plates have attained the naximum development observed in the Strophomenidx.

The last three figures have the same degree of enlargement. 

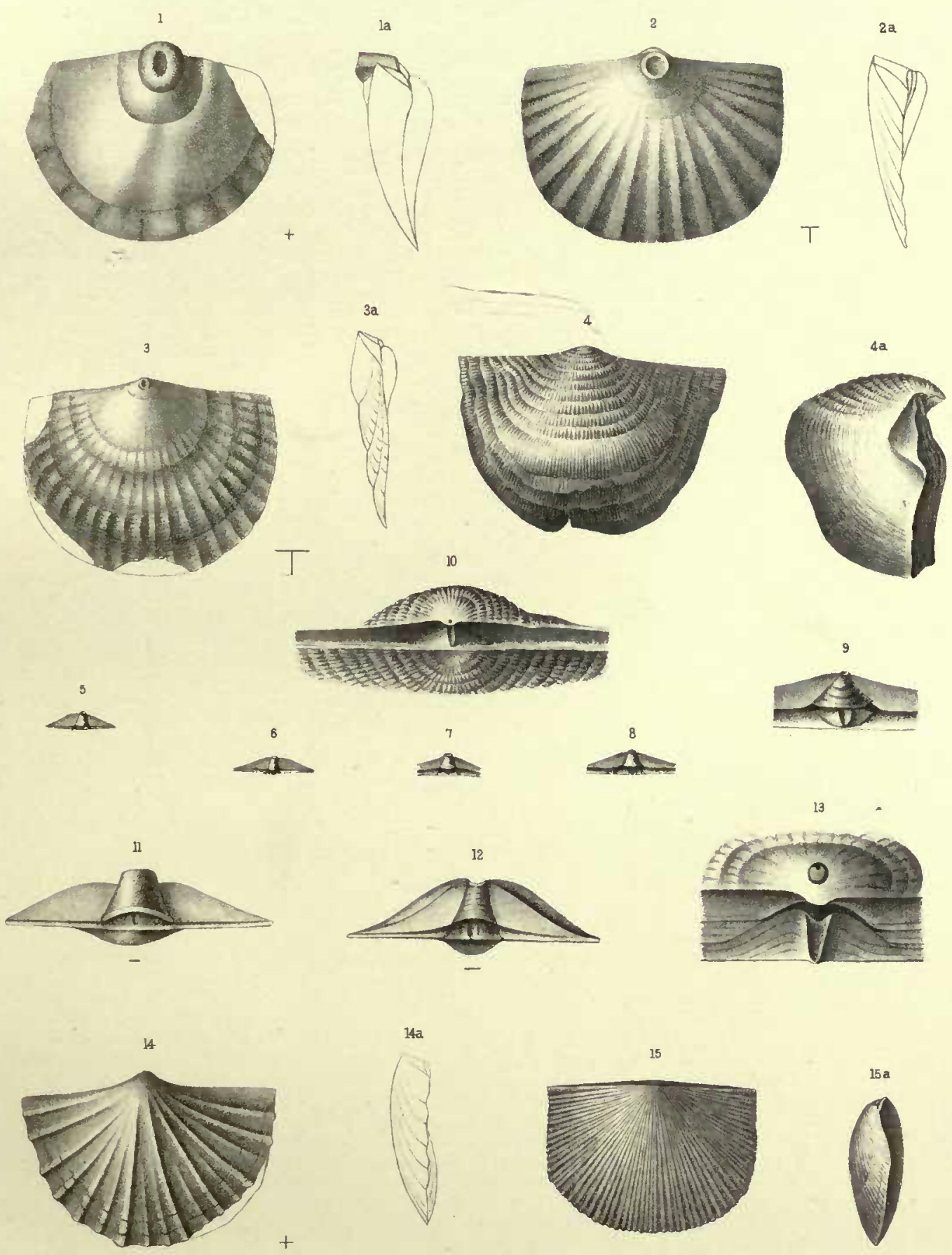

$+$

16
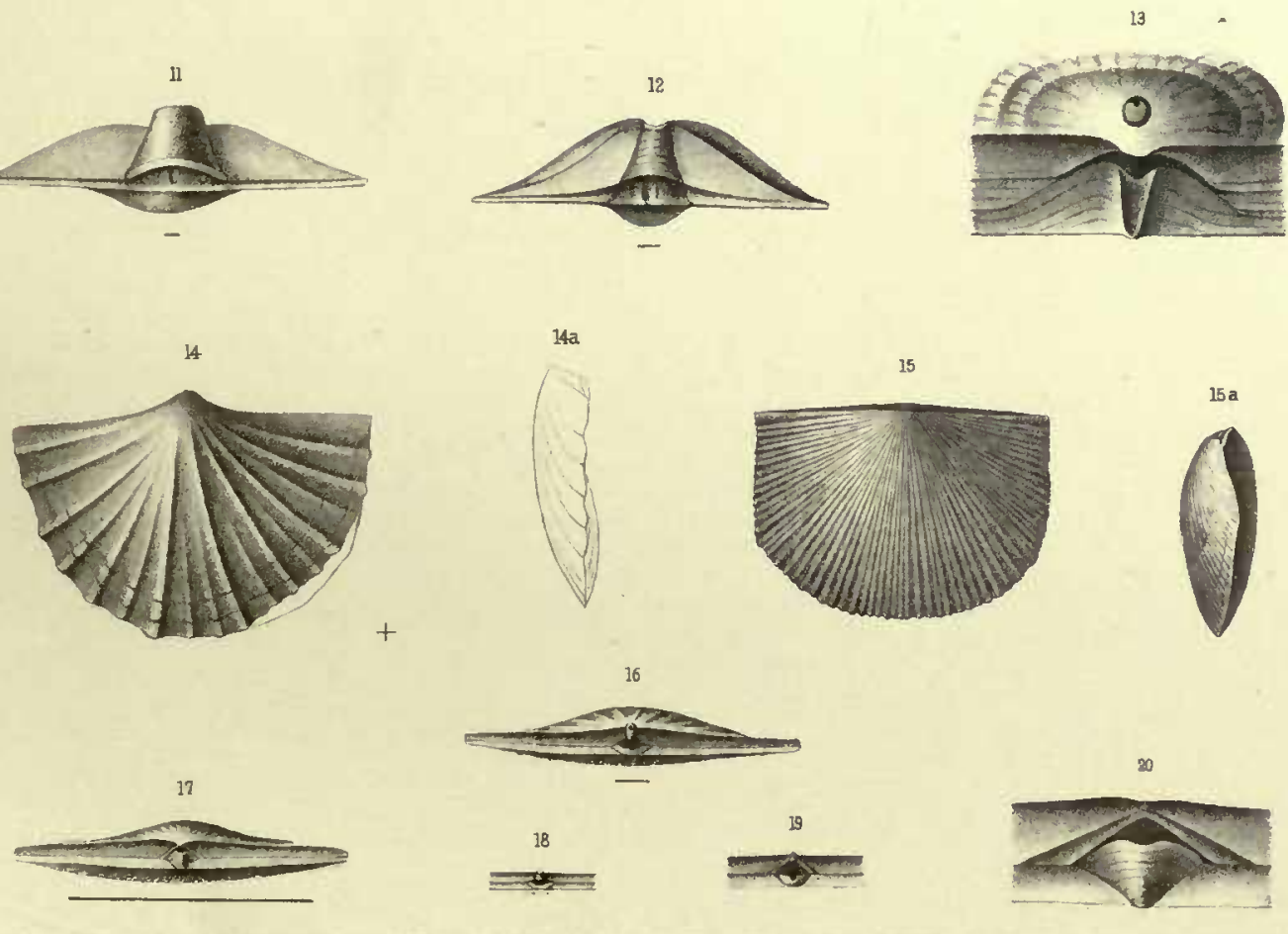

Fhilip Ast, lith

Weed,Parsons \& Co. Albany, N.Y 



\section{HTA.I9}

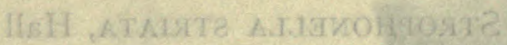

es ege' 4

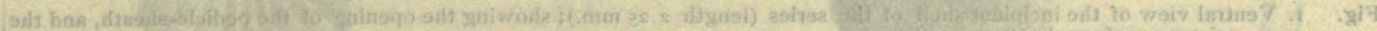

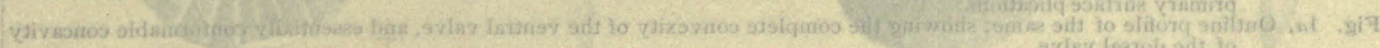

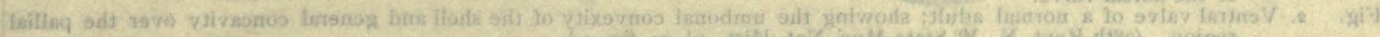
W.

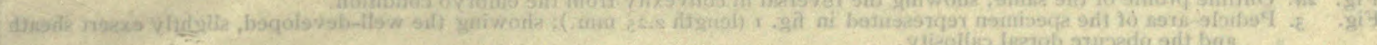

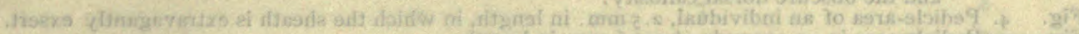

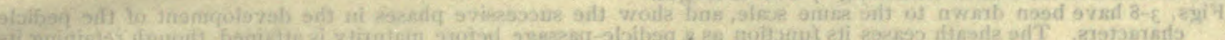
if

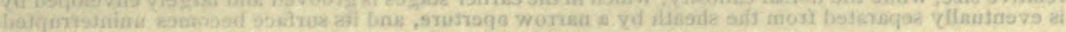

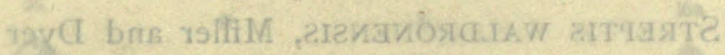

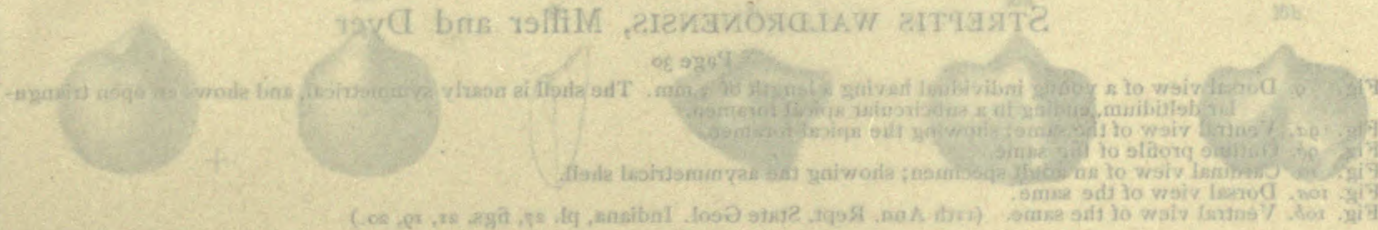

IlsH, ATAMUTTG ATIAWHOH

\section{EXPLANATION OF PLATE III}

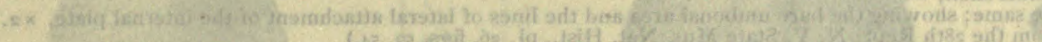

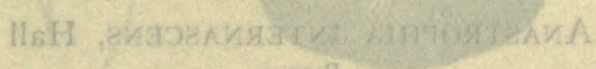

$$
\operatorname{senseq}
$$

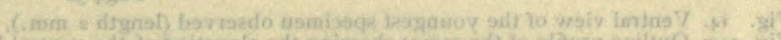

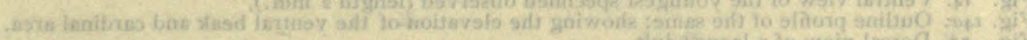

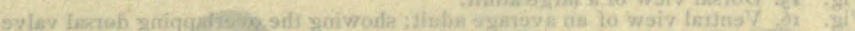

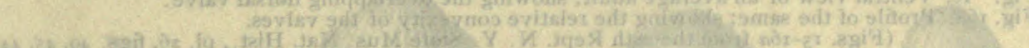

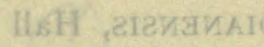

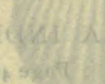

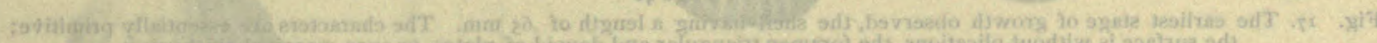

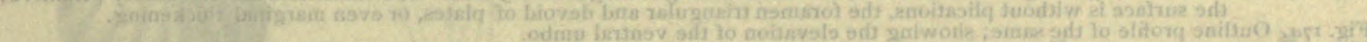

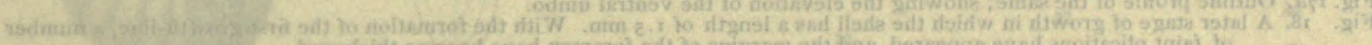

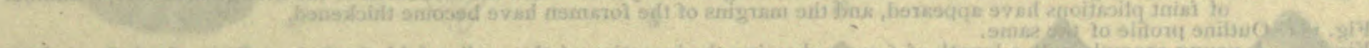

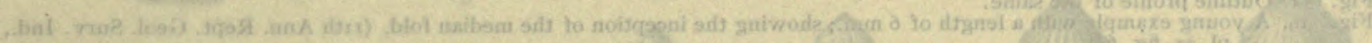

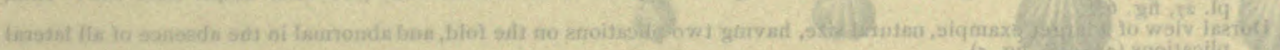

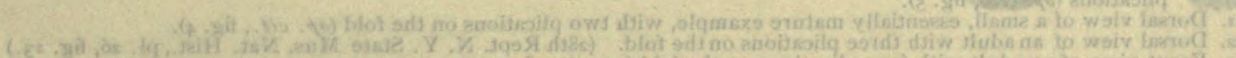

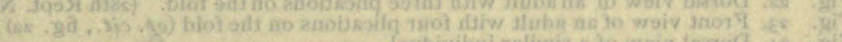

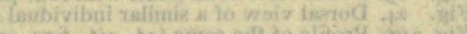

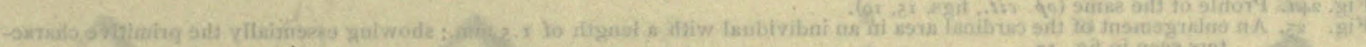

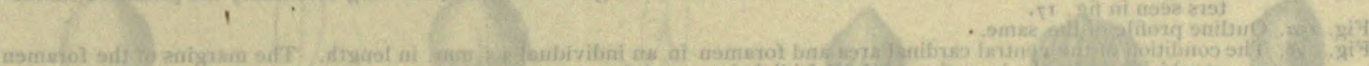

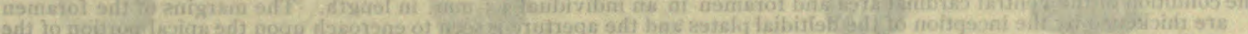

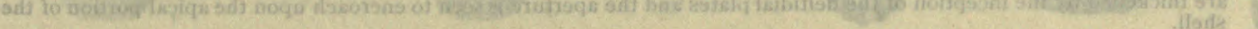

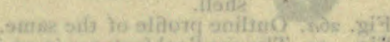

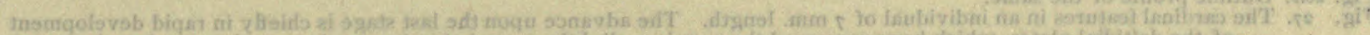

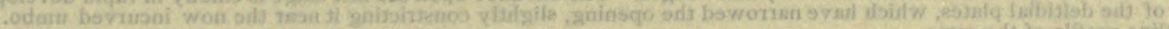

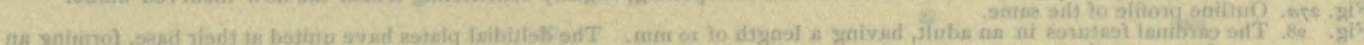

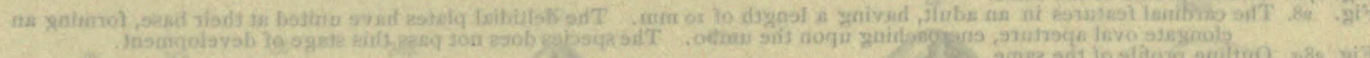
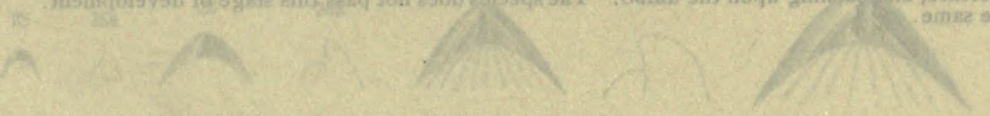


\section{PLATE III \\ Strophonel.LA STRIATA, Hall \\ Page 25}

Fig. 1. Ventral riew of the incipient shell of the series (length $2.25 \mathrm{~mm}$.); showing the opening of the pedicle-sheath, and the

Fig. 1a. Outlime profile of the same; showing the complete convexity of the ventral valve, and esscntially conformable concavity

Fig. 2. Ventral valve of a normal adult; showing the umboeal cnnvexity of the shell and general concavity over the pallial

Fig. 2. Ventral valve of a normal adult; showing the umbooal convexity of

Fig. 2a. Outline profile of the same: showing the reversal in convexity from the embryo condition.
Fig. 3. Pedicle-area of the specimen represented in fig. I (length $2.25 \mathrm{~mm}$.); showing the well-developed, slightly exsert sheath

and the obscure dorsal callosity.

Fig. 4. Pedicle-area of an individual, $2.5 \mathrm{~mm}$. in length, in which the sheath is extravagantly cxsert.

Fig. 5. Pediclc-area in an example about $6 \mathrm{~mm}$, in length.

Fig. 6. Pedicle-area, whon a length of $8 \mathrm{~mm}$. has been attained.

Fig. 7. Pedicle-area in a shell measuring $13 \mathrm{~mm}$. in length.

Fig. 8. l'edicle-area in a normal adult measuring i7 mm. in length.

Figs, 3-8 have been drawn to the same scale, and show the successive phases in the development of the pedicle characters. The shcath ceases its function as a pedicle-passage before maturity is attained, though retaining its
relative size, while the dorsal callosity, which in the earlier stages is grooved and largely enveloped by the sbeath, is eventually separated from the sheath by a varrow aperture, and its surface becomes uninterrupted.

\section{STREPTIS WALDRONENSIS, Miller and Dyer \\ Page 30}

Fig. 9. Dorsal view of a young individual haring a length of $3 \mathrm{~mm}$. The shell is nearly symmetrical, and shows an open triangular deltidium, ending in a subcircular apical foramen.

Fig. $9 a$. Ventral view of the same; showing the apical foramen.

Fig. 96 . Outline profile of the same.

Fig. ro. Cardinal view of an adult specimen; showing the asymmetrical shell.

Fig. Ior. Dorsal view of the same.

Fig. 1ob. Ventral view of the same. (xzth Ann. Rept. State Geol. Indiana, pl. 27, figs. 21, 19, 20.)

\section{EichWaldia RETiCUlata, Hall}

\section{Page $3^{x}$}

Fig. 11. A young inclividual having a length and width of $3 \mathrm{~mm}$ : showing the subcircular outline and undefined medlan fold.

Fig. 12. A xial section of a larger, but immature form; indicating the character of the articulation, and showing the internal ventral Fig. 23. Dorsal view of an adult shell, $\dot{x}_{2}$.

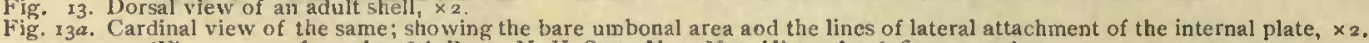
(Figs. $13,13 n$ from the 28 tl Rept. N. Y. State Mus. Nat. Hist., pl. 26, figs. 53, 54.)

\section{ANASTROPHIA INTERNASCENS, Hall}

Page 32

Fig. 14. Ventral view of the youngest specimen observed (length $2 \mathrm{~mm}$.)
Fig. r4 $a$. Ontline profile of the same: showing the elevation of the ventral beak and cardinal area.

lig. 15. Dorsal view of a large aduit.

Fig. 16. Ventral view of an av erage adult; showing the overlapping dorsal valve.

(Figs. 15-16r from the 28 th Rept. N. Y. State Mus. Nat. Hist., pl, 26, figs. 49, 45, 44.)

\section{RHYNCHONELI,A INDIANENSIS, Hall}

\section{Page 42}

Fig. 17. The earliest stage of growth observed, the shell having a length of $65 \mathrm{~mm}$. The characters are essentially primitive: the surface is without plications, the foramen triangular and devoid of plates, or even marginal thickening.

Fig. $17 \pi$. Outline profile of the same; showing the elevation of the ventral umbo.

Fig. 18. A later stage of growth in which the shell has a length of $1.5 \mathrm{~mm}$. With the formation of the first growth-line, a number Fig. $18 a$. Outline profle of the same.

Fig. I9. A young examplc with a length of $6 \mathrm{~mm}$; showing the inception of the median fold. (rrth Ann. Rept. Geol. Surv. Ind., pl. 27, fig. 6.)

Fig. 20. Dorsal view of a larger example, natural size, having two plications on the fold, and abnorinal in the absence of all lateral plications (op. cit. fig. 5$)$.

Fig. 21. Dorsal view of a sulli, essentially mature example, with two plications on the fold (op. cit., fig. 4).

Fig. 22. Jorsal view of an adult with three plications on the fold. (28th Rept. N. Y. State Mius. Nat. Hist., pl. 26, fig. 13.)

Fig. 23. Front view of an adult with four plications on the fold (op. cit., fig. 22)

Fig. 24. Dorsal view of a similar indivirtual.

Fig. $24 a$. Profile of the same (op. cit., figs, 15,19$)$.

Fig. 25. An enlargement of the cardinal area in an individual with a length of $1.5 \mathrm{mn} . ;$ showing essentially the primitive characFig. 25a. Outline seen in fig. 17 .

Fig. 26. The condition of the ventral cardinal area and foramen is an individual $3.5 \mathrm{~mm}$, in length. The margins of the foramen are thickened by the inception of the deltidial plates and the aperture is seen to encroach upon the apicul portion of the shell.

Fig. 26r. Outline profile of the satne.

Fig. 27. The cardinal features in an individual of $7 \mathrm{~mm}$. length. The advance upon the last stage is chiefly in rapid development Fig. $27 \pi$. Outline profile of the saine.

lig. 28. The cardinal features in an adult, having a length of ro mun. The deltidial plates have united at their base, formiog an Fig. $28 a$. Ontline profile of the same. 
BIAAIIIOFODA.

MEMI.N.Y.STATE MUS.

PIAIEIII.
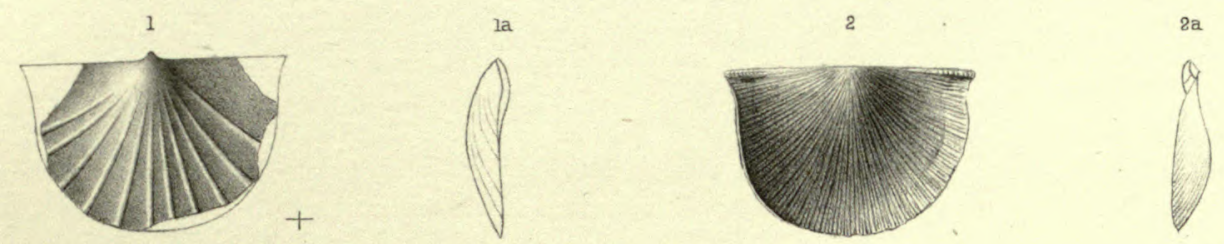

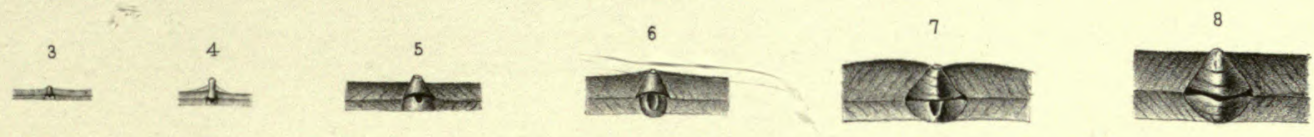
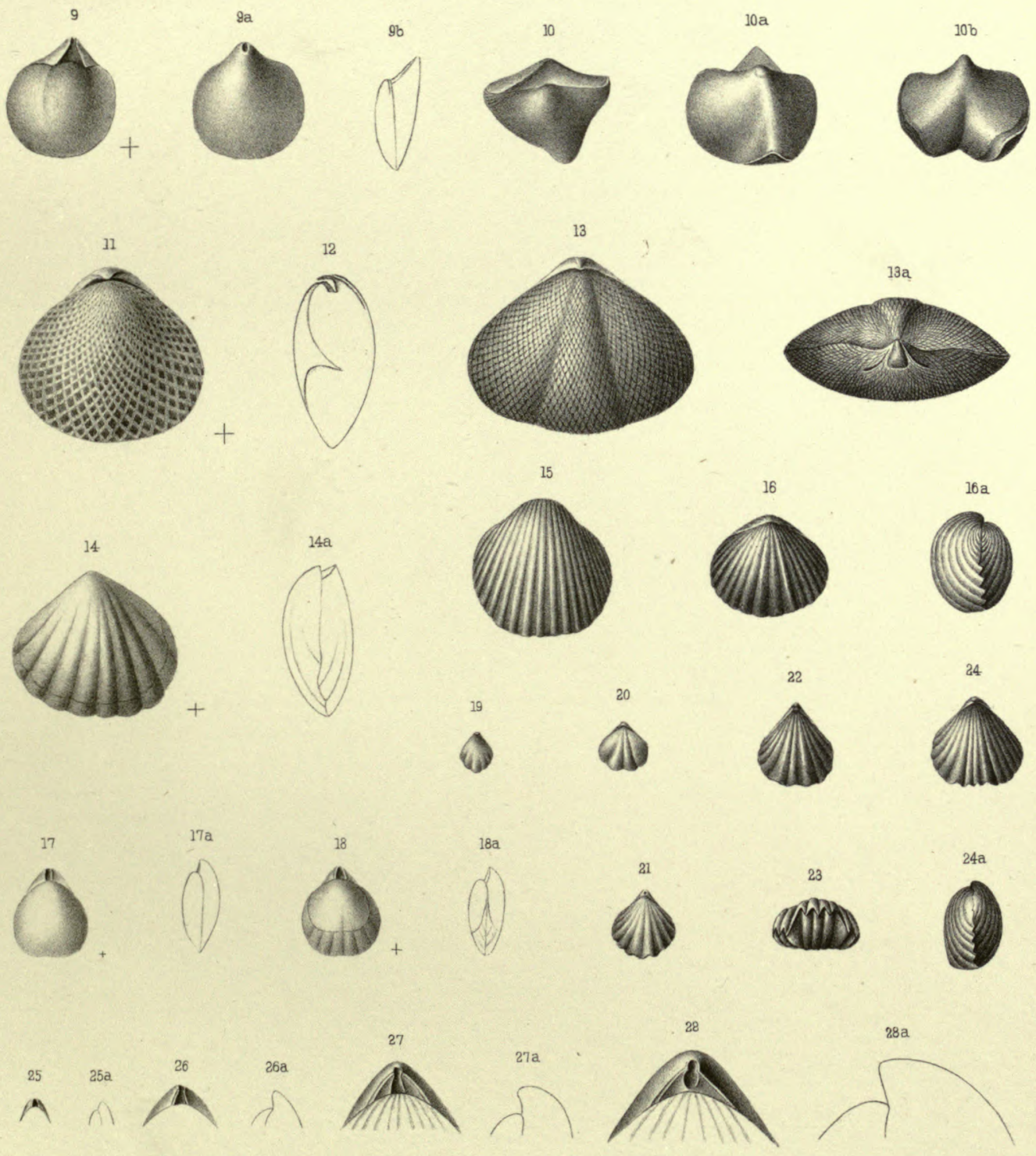



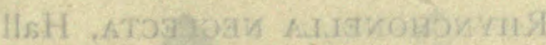

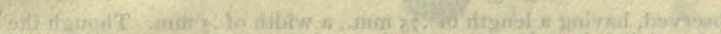
and

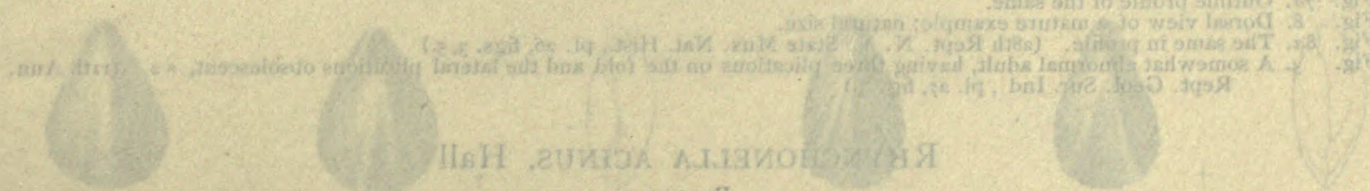
28 oye 9

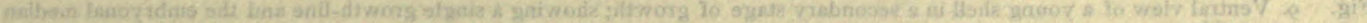
HXPIANATIONOF PIATE IV

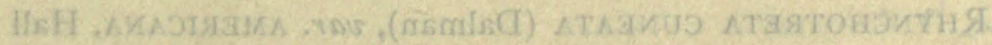
Tit 3929 (ii) atsity 9 ?

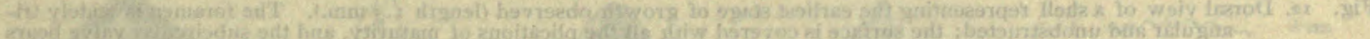

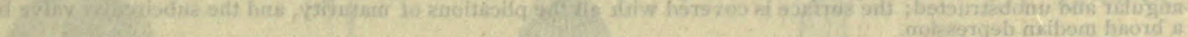

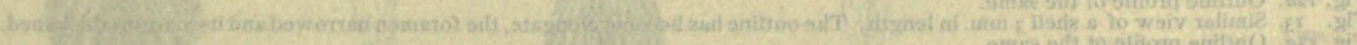

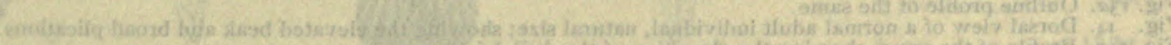

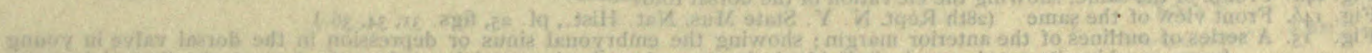

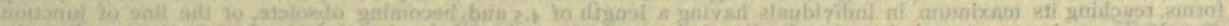

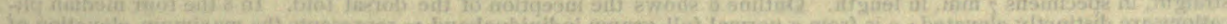

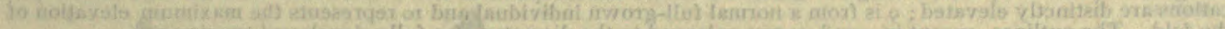

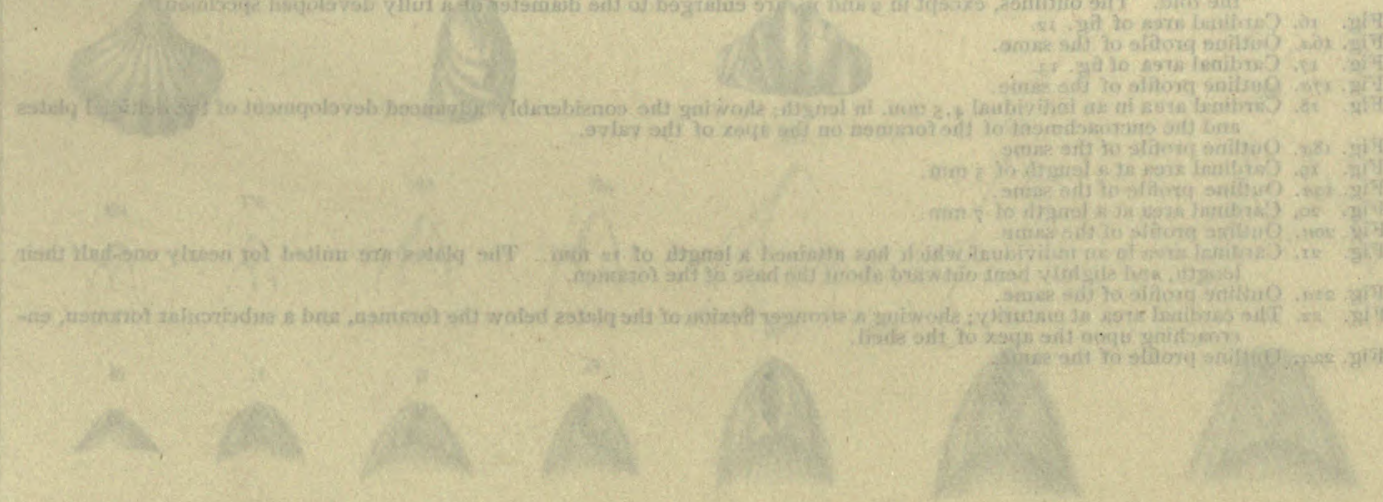




\section{PLATE IV}

\section{RHYNCHONELLA whitit, Hall}

Page 39

Fig. I. The earliest observed stage of growth, the shell measuring $2.75 \mathrm{~mm}$. io length by $2 \mathrm{~mm}$ in width. The deltidial plates have already begun to form along the edges of the triangular foramen, and four pairs of plications are visible on the dorsal valve.

Fig. I $\alpha$. Outline profile of the same.

Fig. 2 Dorsal view of a normal adult having two plicatioos on the fold; natural size.

Fig. 2a. Profile of the same.

Fig. 2b. Front view of the same. (28th Rept. N. Y. State Mus. Nat. Hist, pl. 26, figs. 23, 26, 25 .)

Fig. 4. The cardinal features of a young example with a length of $3.25 \mathrm{~mm}$; shoiving the inception of the deitidial plates.

Fig. 4a. Profile of the same.

Fig. 5. Cardinal features of an individual which has attained a length of $6 \mathrm{~mm}$. The unbo has become incurved and the developthent of the plates is well advanced, but it is arrested at this stage, the foramen not hecoming inclosed at inaturity
Fig. $5 a$. Outline profile of the same.

\section{RhyNCHONELla NEGLECTA, Hall}

\section{Tage 37}

Fig. 6. Dorsal view of the youngest shell observed, having a leogth of $.75 \mathrm{~mm}$, a width of $.5 \mathrm{~mm}$. Though the foramen is open and without evidence of thickened margins, four fine plications have already appeared on the dorsal valve.

Fig. 7. Darsal view of an individual with a length of $2.25 \mathrm{~mm}$. The deltidial plates are in an incipient condition, and the plications of the surface have considerably increased.

Fig. 7a. Outline profile of the same.

Fig. 8. Dorsal view of a mature example; natural size.

Fig. $8 \pi$. The same in profile. (28th Rept. N. Y. State Mus. Nat, 1list., pl. 26, figs. 3,5.) Rept. Geol. Sur. Ind pl, 27, fig. 3 )

\section{RHYNCHONELLA ACINUS, Hall}

\section{Page 35}

Fig. 9. Ventral view of a young shell in a secondary stage of growth; showing a single growth-line and the embryonal median

Fig. $9 a$. Dorsal view of the same. The foramen is slightly narrowed, but without evidence of deltidial plates; the embryonal Fig. $9 b$. Outine profile of the same.

Fig. ro. Ventral view of a specimen $3.25 \mathrm{~mm}$. in jength.

Fig. roa. Dorsal view of the same. The mature fold and sinus have not yet beguo to develop; the foramen shows increased conFig. 20b. Outline profile of the same.

Fig. xi. Dorsal view of an average adult, $x$

Fig. 11a. Profile of the same.

Fig. irb. Front view of the same; showing the elevation of the median fold.

\section{RhynChotreta CUNEATA (Dalman), var. AMERICANA, Hall Page 47 \\ See l'late viii}

Fig. 12. Dorsal view of a shell representing the earliest stage of growth observed (length I.5 mm.). The foramen is widely triangular and unobstructed; the surface is covered with all the plications of maturity, and the subcircular valve bears a broad median depression.

Fig. ra. Outline profile of the same.

Fig. 13. Similar view of a shell $3 \mathrm{~mm}$, in length. The outline has become elongate, the foramen narrowed and its margins thickened. Fig. 13a. Outline profile of the same.

Fig. I4. Dorsal view of a normal adult individual, natural size; showing the elevated beak and broad plications.

Fig. 14a. Profile of the same, showing the ele vation of the dorsal fold.

Fig. I $b$. Front view of the same (28th Rept. N. Y. State Mus. Nat. Ilist., pl. 25, figs. 31, 34, 36.)

Fig. 15. A series of outlines of the anterior margin; showing the embryonal sinus or depression in the dorsal valve in young forms, reaching its maximum in individuals having a length of $4-5$ and becoming ohsolete, or the line of junction straight, in specimens $7 \mathrm{~mm}$. in length. Outline 6 shows the inception of the dorsal fold. In 8 the four median plithe fold. The outlines, except in 9 and so, are enlarged to the diameter of a fully developed specimen.

Fig. 16. Cardinal area of fig. 12 .

Fig. $16 \%$. Outline proble of the same.

Fig. 17. Cardinal area of fig. 13.

Fig. 17a. Outline profile of the same.

Fig. 18. Cardinal area io an indixidual $4.5 \mathrm{~mm}$. in length; showing the considerably advanced developmeot of the deltidial plates and the encroachment of the foramen on the apex of the valve.

Fig. $18 \pi$. Outline profile of the same

Fig. 29. Cardinal area at a leogth of $5 \mathrm{~mm}$

Fig. Ign. Outlioe profile of the same.

Fig. 20, Cardinal area at a length of $7 \mathrm{~mm}$

Fig. 2on. Outline profile of the same.
Fig. 2r. Cardinal area in an individual which has attained a length of $\mathrm{t2} \mathrm{mm}$. The plates are united for nearly one-half their Fig. 21 $\%$. Outlingth, and slightly bent

Fig. 22. The cardiaal area at maturity; showlng a stronger fiexion of the plates below the foramen, and a subcircular foramen, enFig. 22a. Outline profle of the same. 

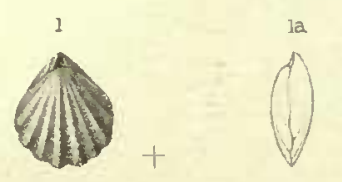

a

i
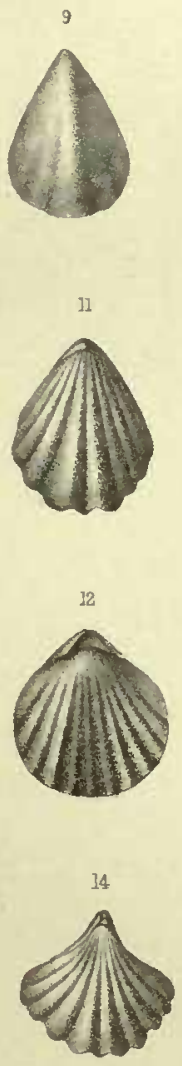

$N^{16 a}$

16
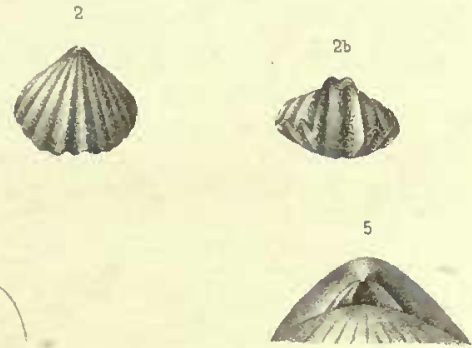

-
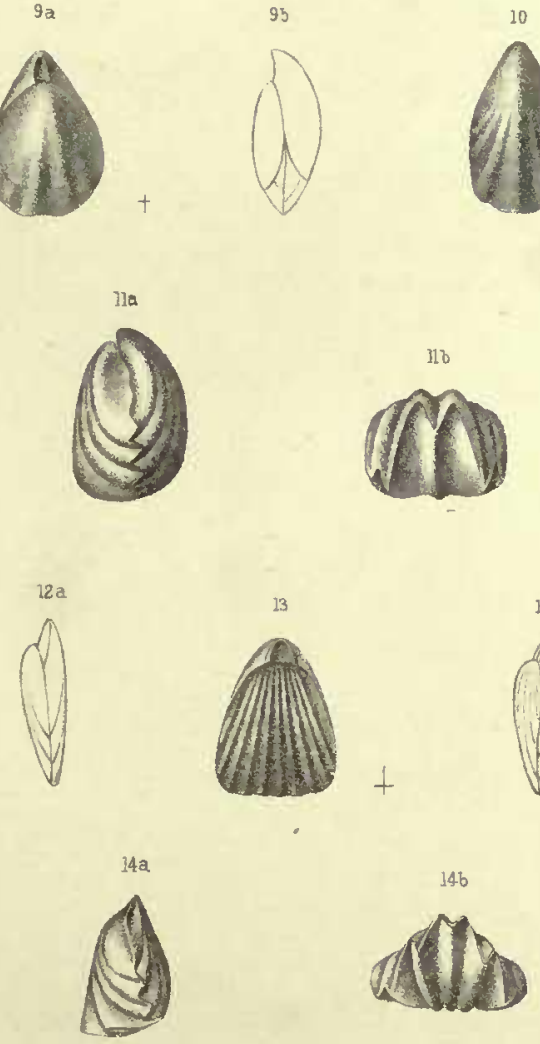

zoa
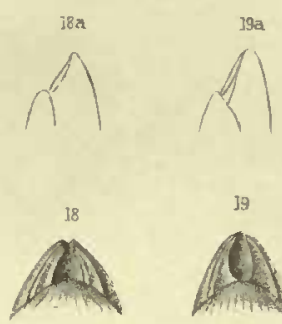

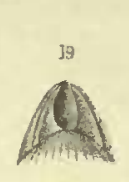

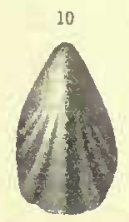

(1)
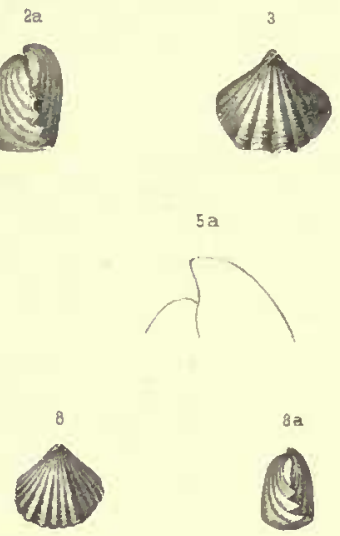

(3)
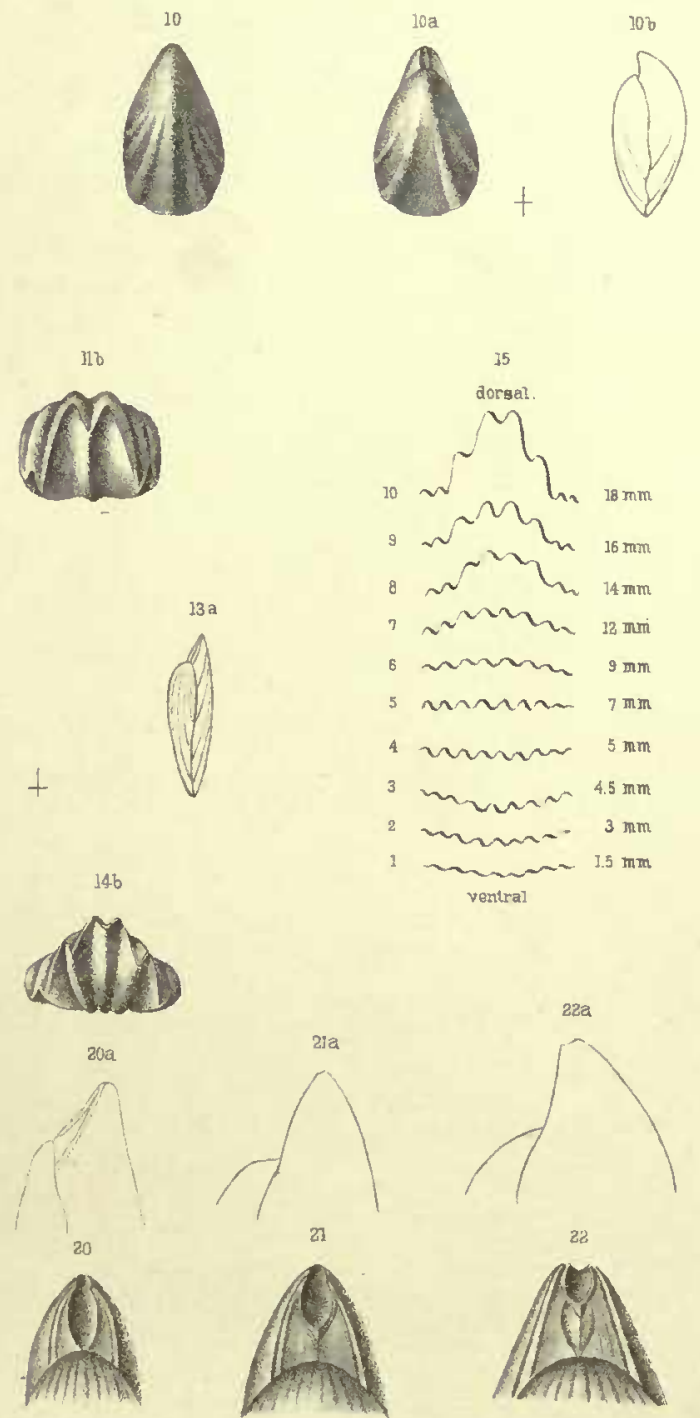



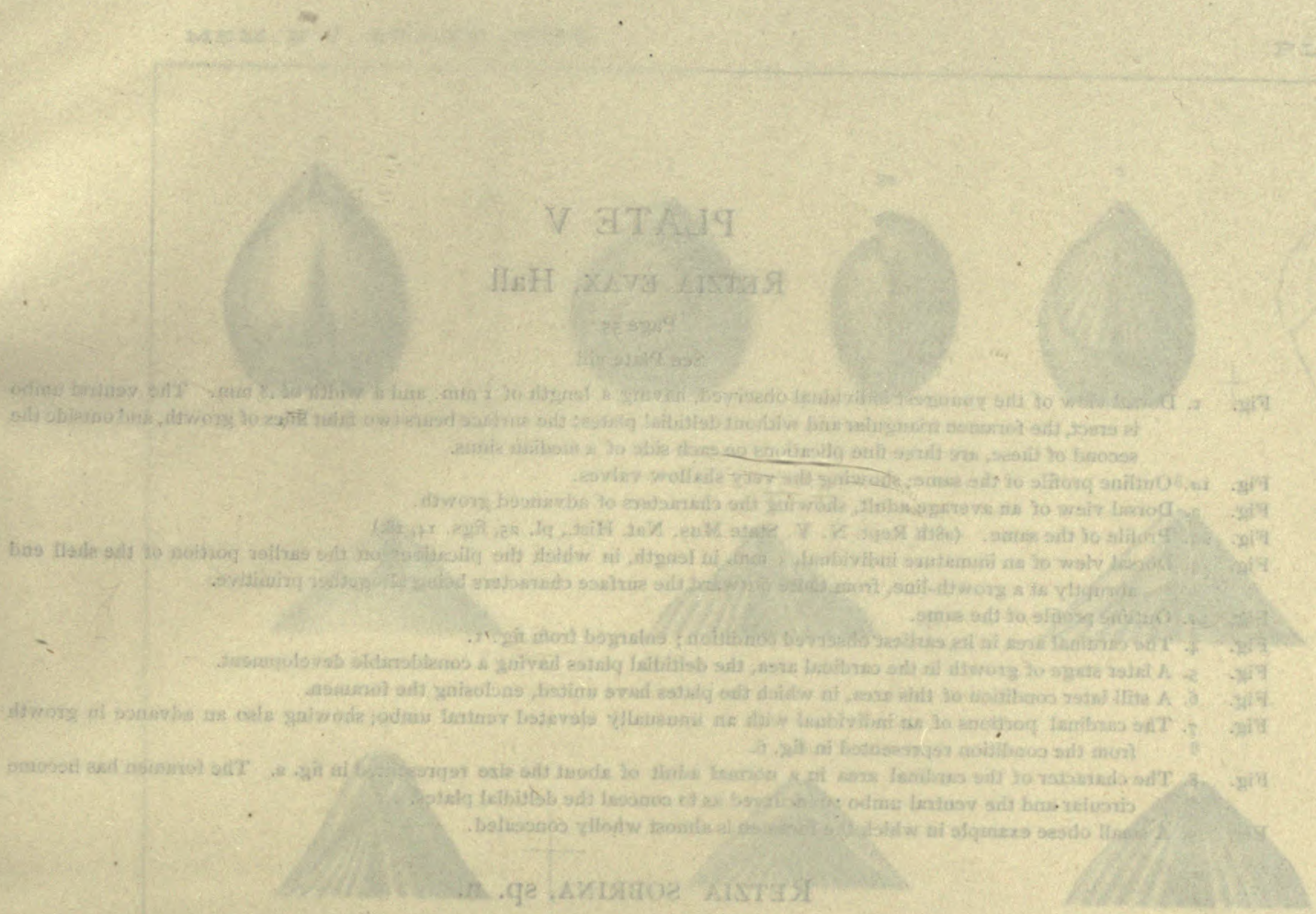

20.0984

\section{EXPLANATION OF PLATE V}

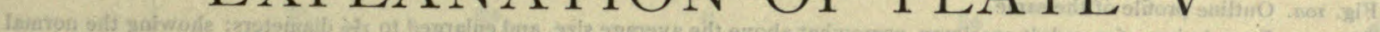

Y.

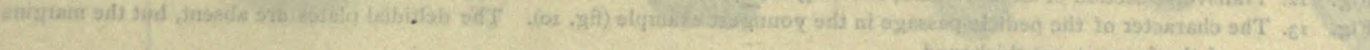

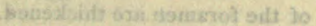

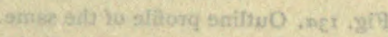

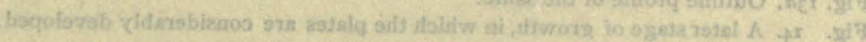

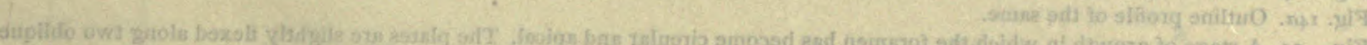

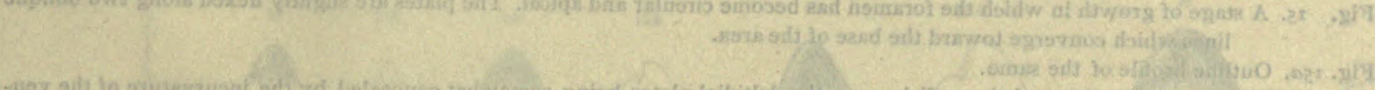

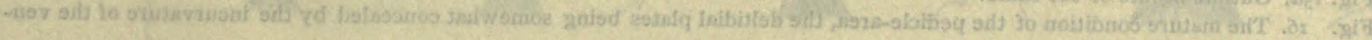

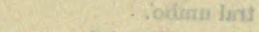

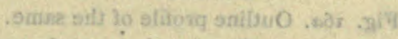

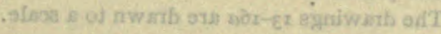

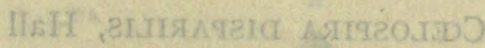

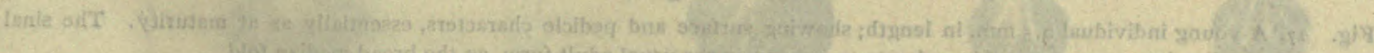

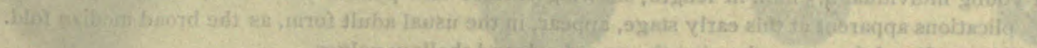

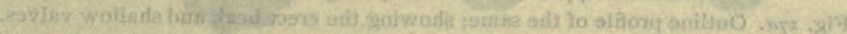

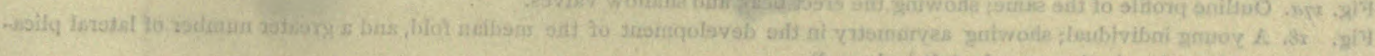

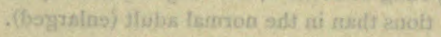

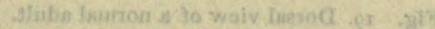

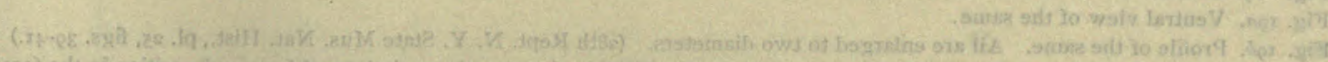

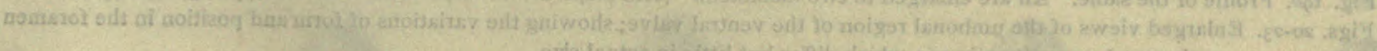

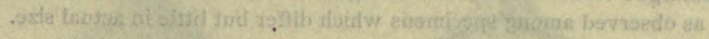




\section{PLATE V}

\section{RETZIA EVAX, Hall \\ Page 55 \\ See Plate viii}

Fig. I. Dorsal view of the youngest individual observed, having a length of $\mathrm{Imm}$. and a width of $.8 \mathrm{~mm}$. The ventral umbo is erect, the foramen triangular and without deltidial plates; the surface bears two faint lines of growth, and outside the second of these, are three fine plications on each side of a median sinus.

Fig. sa. Ontline profile of the same; showing the very shallow valves.

Fig. 2. Dorsal view of an average adult, showing the characters of advanced growth.

Fig. 2a. Profile of the same. (28th Rept. N. Y. State Mus. Nat. Hist., pl. 25, figs. 14, 18.)

Fig. 3. Dorsal view of an immature individual, $5 \mathrm{~mm}$. in length, in which the plications on the earlier portion of the shell end abruptly at a growth-line, from there outward the surface characters being altogether primitive.

Fig. 3a. Ontline profile of the same.

Fig. 4. 'The cardinal area in its, earliest observed conditlon; enlarged from fig. $x$.

Fig. 5. A later stage of growth in the cardinal area, the deltidial plates having a considerable development.

Fig. 6. A still later condition of this area, in which the plates have united, enclosing the foramen.

Fig. 7. The cardinal portions of an individual with an unusually elevated ventral umbo; showing also an advance in growth from the condition represented in fig. 6 .

Fig. 8. The character of the cardinal area in a normal adult of abont the size represented in fig. 2. The foramen has become circular and the ventral umbo so incurved as to conceal the deltidial plates.

Fig. 9. A small obese example in which the foramen is almost wholly concealed.

\section{RETZIA SOBRINA, sp. $\mathrm{n}$. \\ Page 6r}

Fig. 10. The youngest shell observed, having a length of $2 \mathrm{~mm}$, and a width of $1.6 \mathrm{~mm}$. The shell already bears two plications on each side of the median sinus, and two much fainter elevated striae in the sinus itself.

Fig. ron. Outline profile of the same.

Fig. Ir. Dorsal view of an adult specimen, somewhat above the average size, and enlarged to 13 diameters; showing the normal features of maturity

Fig. Ira. Profile of the same.

Fig. $x \not b$. Ventral view of the same individual; natural size.

Fig. 12. Transverse section of an individual; showing the spiral ribbon and the number of volutions.

Fig. 13. The character of the pedicle-passage in the youngest example (fig. 10). The deltidial plates are absent, but the margins of the foramen are thickened.

Fig. I3a. Outline profile of the same.

Fig. I4. A later stage of growth, in which the plates are considerably developed.

Fig. $14 \alpha$. Outline profile of the same.

Fig. 15. A stage of growth in which the foramen has become circular and apical. The plates are slightly flexed along two oblique lines which converge toward the base of the area.

Fig. $15 a$. Ontline profile of the same.

Fig. 16. The mature condition of the pedicle-area, the deltidial plates being somewhat concealed by the incurvature of the veotral umbo.

Fig. r6a. Outline profile of the same.

The drawings $13-r 6 a$ are drawn to a scale.

\section{Celospira disparilis, Hall}

Page 64

Fig. ${ }^{7}$. A young individual $2.5 \mathrm{~mm}$. in length; showing surface and pedicle characters, essentially as at maturity. The sinal plications apparent at this early stage, appear, in the usual adult form, as the broad median fold.

Fig. $17 a$. Outline profile of the same: showing the erect beak and shallow valves.

Flg. 18. A young individual; showing asymmetry in the development of the median fold, and a greater number of lateral plications than in the normal adult (eolarged).

Fig. 19. Dorsal view of a normal adult.

Fig. Iga. Ventral view of the same.

Fig. 1gb. Profile of the same. All are enlarged to two diameters, (28th Rept. N. Y. State M us. Nat. Hist., pl. 25, figs. 39-4x.)

Figs. 20-23. Enlarged views of the umbonal region of the ventral valve; showing the variations of form and position in the foramen as observed among specimens which differ but little in actual size. 

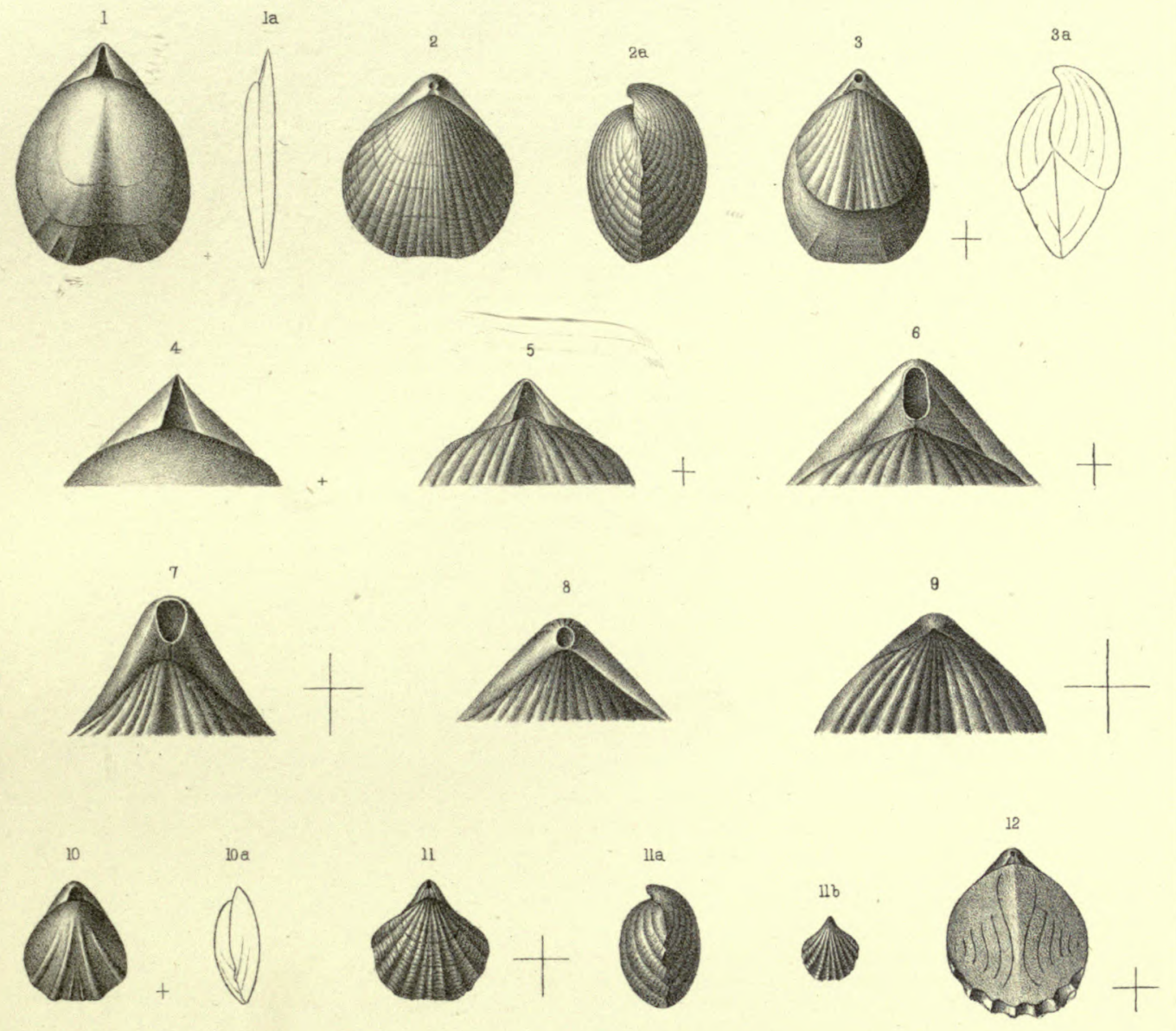

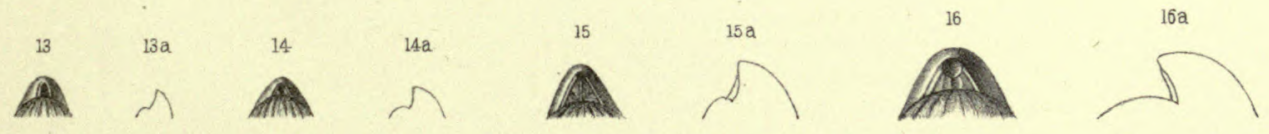
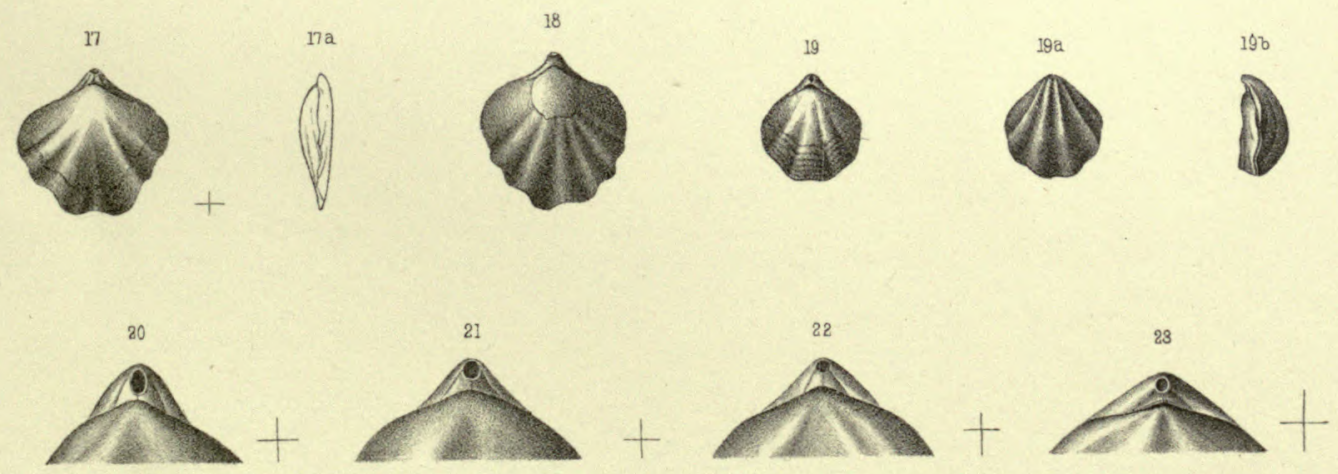



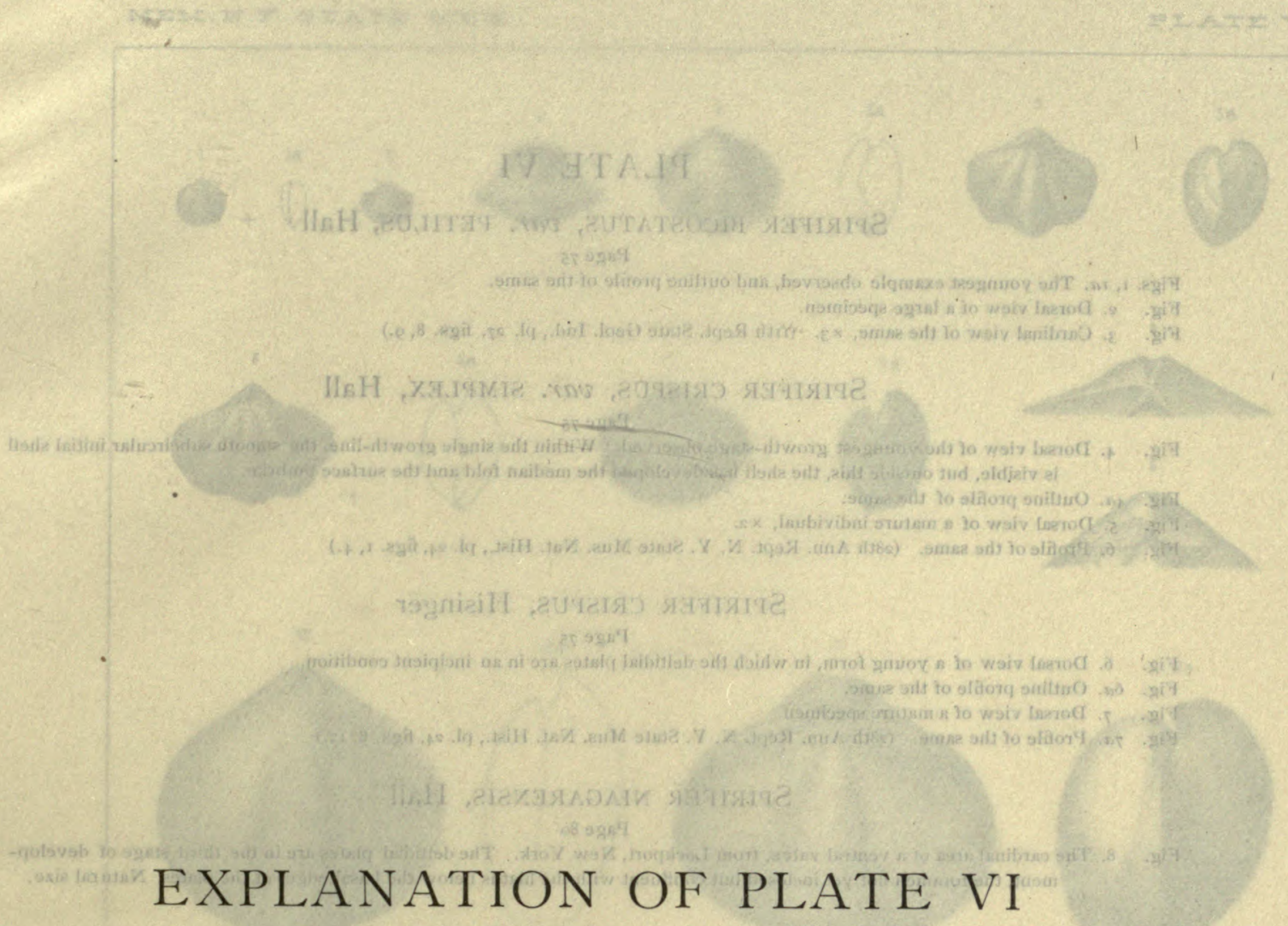

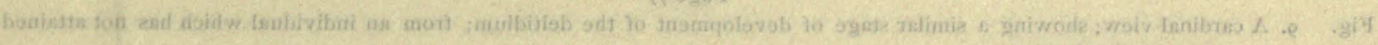

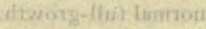

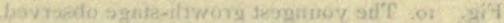

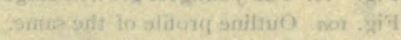

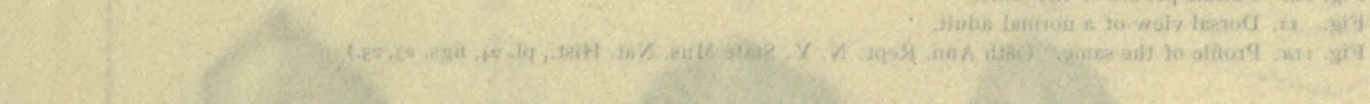

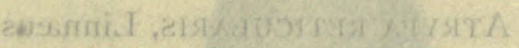

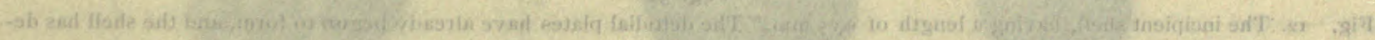

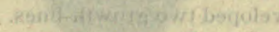

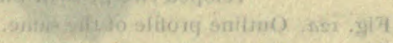

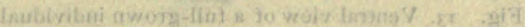

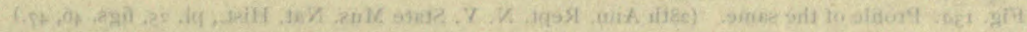

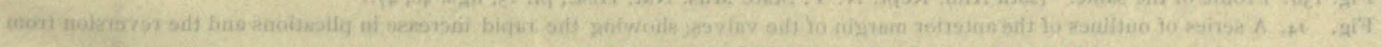

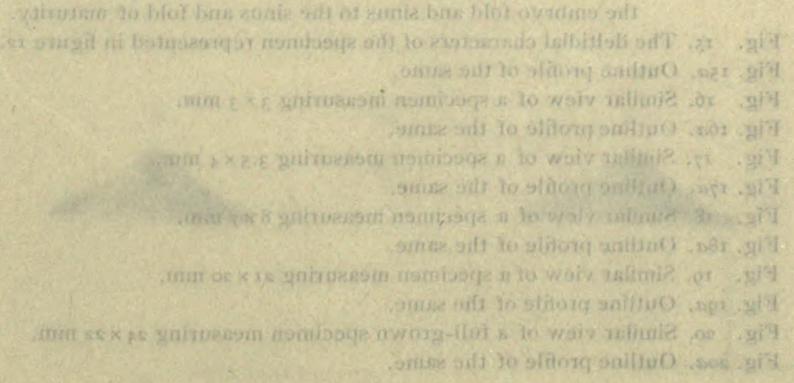




\section{PLATE VI}

\section{SPIRIFER BICOSTATUS, var. PETILUS, Hall}

Page 75

Figs, I, Ja. The youngest example observed, and outline profile of the same.

Fig. 2. Dorsal view of a large specimen.

Fig. 3. Cardinal view of the same, $\times 3$. (irth Rept. State Geol. Ind., pl. 27, figs. 8, 9.)

\section{SPIRIFER CRISPUS, var. SIMPLEX, Hall \\ Page 75}

Fig. 4. Dorsal view of the youngest growth-stage observed. Within the single growth-line, the smooth subcircular initiai shell is visible, but outside this, the shell has developed the median fold and the surface fimbriae.

Fig. 4n. Outline profile of the same.

Fig. 5. Dorsal view of a mature individual, $\times 2$

Fig. 6. Profile of the same. (28th A nn. Rept. N. Y. State Mus. Nat. Hist., pl. 24, figs. I, 4.)

\section{SPIRIFER CRISPUS, Hisinger \\ Page 75}

Fig. 6. Dorsal view of a young form, in which the deltidial plates are in an incipient condition.

Fig. 6a. Outline profile of the same.

Flg. 7. Dorsal view of a mature specimen.

Fig. 7a. Profile of the same. (28th Ann. Rept. N. Y. State Mus. Nat. Hist., pl, 24, figs. 8, 12.)

\section{SPIRIFER Niagarensis, Hall}

Page 80

Fig. 8. The cardinal area of a ventral valve, from Lockport, New York. The deltidial plates are in the third stage of development, the foramen not yet inclosed but contluent with the hiatus bclow the basal edges of the plates. Natural size.

\section{SPIRIFEr Radiatus, Sowerby}

Page 77

Fig. 9. A cardinal view: showing a similar stage of development of the deltidium; from an individual which has not attained norinal full-growth.

Fig. 1o. The youngest growth-stage observed.

Fig. Ioa. Outline profile of the same.

Fig. 11. Dorsal view of a normal adult.

Fig. rna. Profile of the same. (28th Ann. Rept. N. Y. State Mus. Nat, Hist., pl. 24, figs. 23, 25.)

\section{ATRYPA RETICUlaris, Linnæus}

Page $5 \mathrm{I}$

Fig. 12. The incipient shell, having a length of $2.25 \mathrm{inm}$. The deltidial plates have already begun to form, and the shell has developed two growth-lines.

Fig. r2a. Outline profile of the same.

Fig. $x_{3}$. Ventral view of a full-grown individual.

Fig. I3n. Profile of the same. (28th Ann. Rept. N. Y. State Mus. Nat. Hist., pl. 25, figs, 46, 47.)

Fig. 14. A series of outlines of the anterior margin of the valves; showing the rapid increase in plications and the reversion from the embryo fold and sinus to the sinus and fold of maturity.

Fig. 15. The deltidial characters of the specimen represented in figure 12

Fig. $15 n$. Outline profile of the same.

Fig. 16. Similar view of a specimen mcasuring $3 \times 3 \mathrm{~mm}$.

Fig. $x 6 n$. Outline profile of the same.

Fig. 17. Similar view of a specimen measuring $3.5 \times 4 \mathrm{~mm}$.

Fig. I7a. Outline profile of the same.

Fig. 18. Similar view of a specimen measuring $8 \times 7 \mathrm{~mm}$

Fig. r8a. Outline profile of the same.

Fig. xg. Similar view of a speelmen measuring $2 \times \times 20 \mathrm{~mm}$

Fig. 1ga. Outline profile of the same.

Fig. 20. Similar view of a full-grown speclmen measuring $24 \times 22 \mathrm{~mm}$.

Fig. 2oa. Outline profile of the same. 
BEACIIIOFODA.

MEMI.I.Y. STATE MUS

PIATEVI.
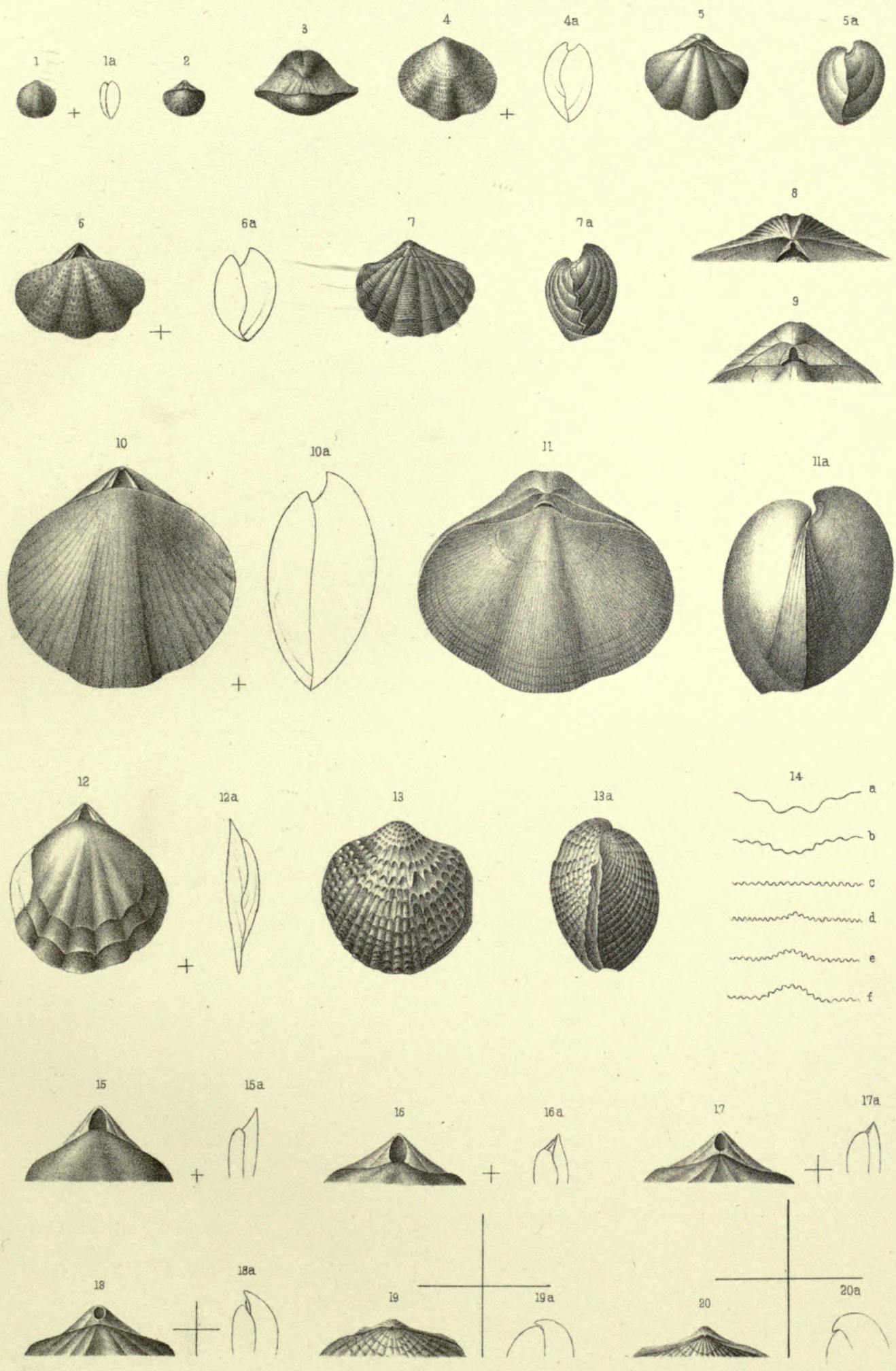



\section{HIU ATA.IT}

HBH .AIXAK A7CHATCHYH

$$
\text { es s.s. }
$$

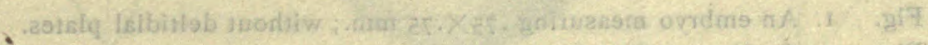

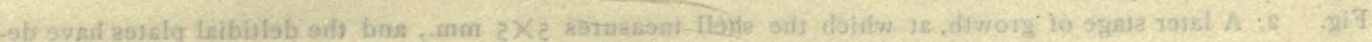

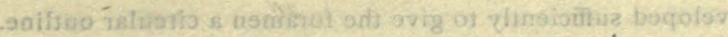

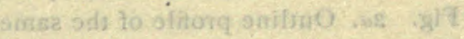

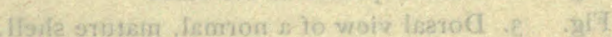

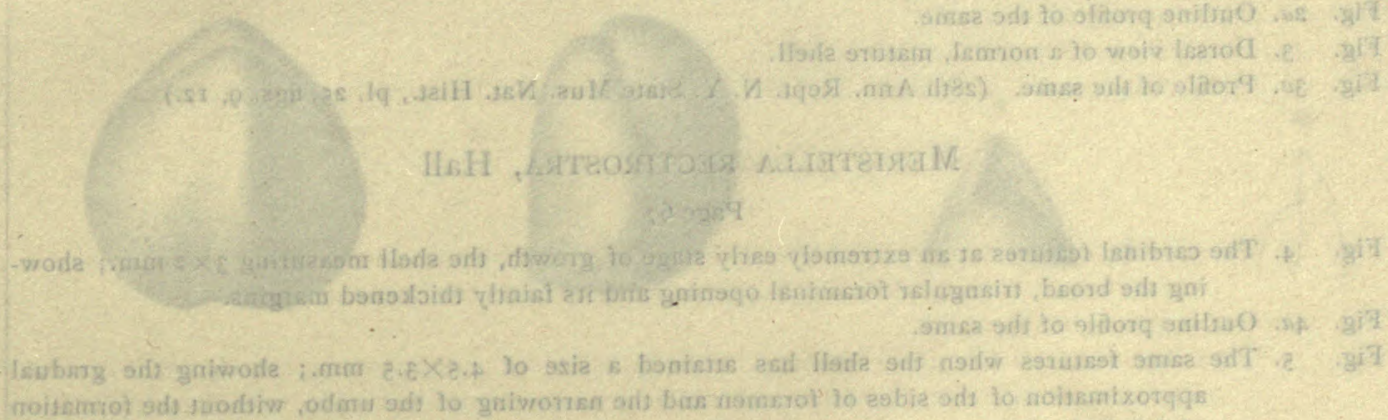

\section{EXPLANATION OF PLATE VII}

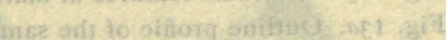

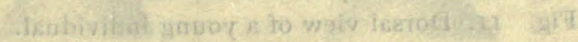

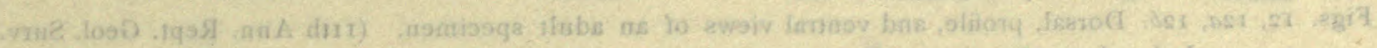

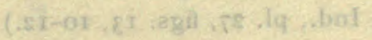

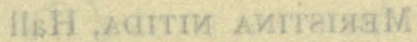 \\ or oxis}

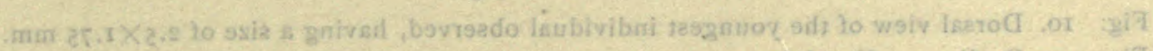
strise sils to stitore anthuo not . gi

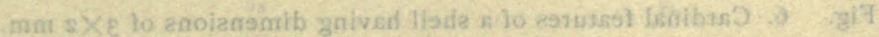

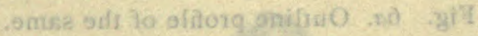

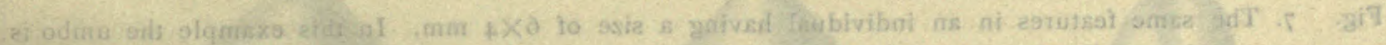

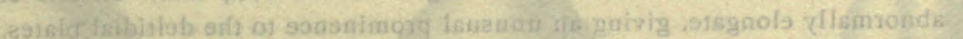

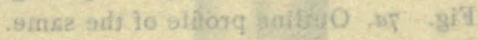

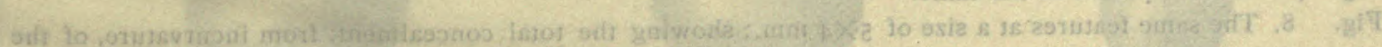
asield labbioloh

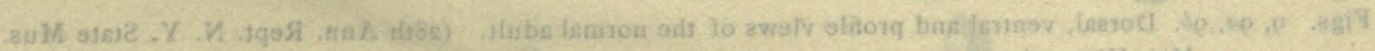

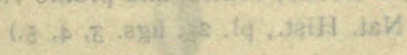




\section{PLATE VII \\ WhITFIELDIA MARIA, Hall \\ Page 73}

Fig. I. An embryo measuring $.75 \times .75 \mathrm{~mm}$.; without deltidial plates.

Fig. I $a$. Outline profile of the same.

Fig. 2. A later stage of growth, at which the shell measures $5 \times 5 \mathrm{~mm}$, and the deltidial plates have developed sufficiently to give the foramen a circular outline.

Fig. 2a. Outline profile of the same.

Fig. 3. Dorsal view of a normal, mature shell.

Fig. 3a. Profile of the șame. (28th Ann. Rept. N. Y. State Mus. Nat. Hist., pl. 25, figs. 9, 22.)

\section{Meristella rectirostra, Hall \\ Page 67}

Fig. 4. The cardinal features at an extremely early stage of growth, the shell measuring $3 \times 2 \mathrm{~mm}$.; showing the broad, triangular foraminal opening and its faintly thickened margins.

Fig. 4a. Outline profile of the same.

Fig. 5. The same features when the shell has attained a size of $4.5 \times 3.5 \mathrm{~mm}$; showing the gradual approximation of the sides of foramen and the narrowing of the umbo, without the formation of deltidial plates.

Fig. 5a. Outline profile of the same.

Fig. 13. The same features at maturity.

Fig. 13a. Outline profile of the same.

Fig. I1. Dorsal view of a young individual.

Figs. 12, 12a, $12 b$. Dorsal, profile, and ventral views of an adult specimen. (I Ith Ann. Rept. Geol. Surv. Ind., pl. 27, figs. 13, 10-12.)

\section{Meristina nitida, Hall \\ Page 70}

Fig. Io. Dorsal view of the youngest individual observed, having a size of $2.5 \times 1.75 \mathrm{~mm}$.

Fig. Ion. Outline profile of the same.

Fig. 6. Cardinal features of a shell having dimensions of $3 \times 2 \mathrm{~mm}$.

Fig. 6a. Outline profile of the same.

Fig. 7. The same features in an individual having a size of $6 \times 4 \mathrm{~mm}$. In this example the umbo is abnormally elongate, giving an unusual prominence to the deltidial plates.

Fig. 7a. Outline profile of the same.

Fig. 8. The same features at a size of $5 \times 4 \mathrm{~mm}$.; slowing the total concealment, from incurvature, of the deltidial plates.

Fig. $8 a$. Outline profile of the same.

Figs. 9, $9 a, 9^{b}$. Dorsal, ventral and profile views of the normal adult. (28th Ann. Rept. N. Y. State Mus. Nat. Hist., pl. 25, figs. 3, 4, 5.) 
BFACIIIOPODA.

MEMI.N.Y.STATE MUS.

PIAIEVII.

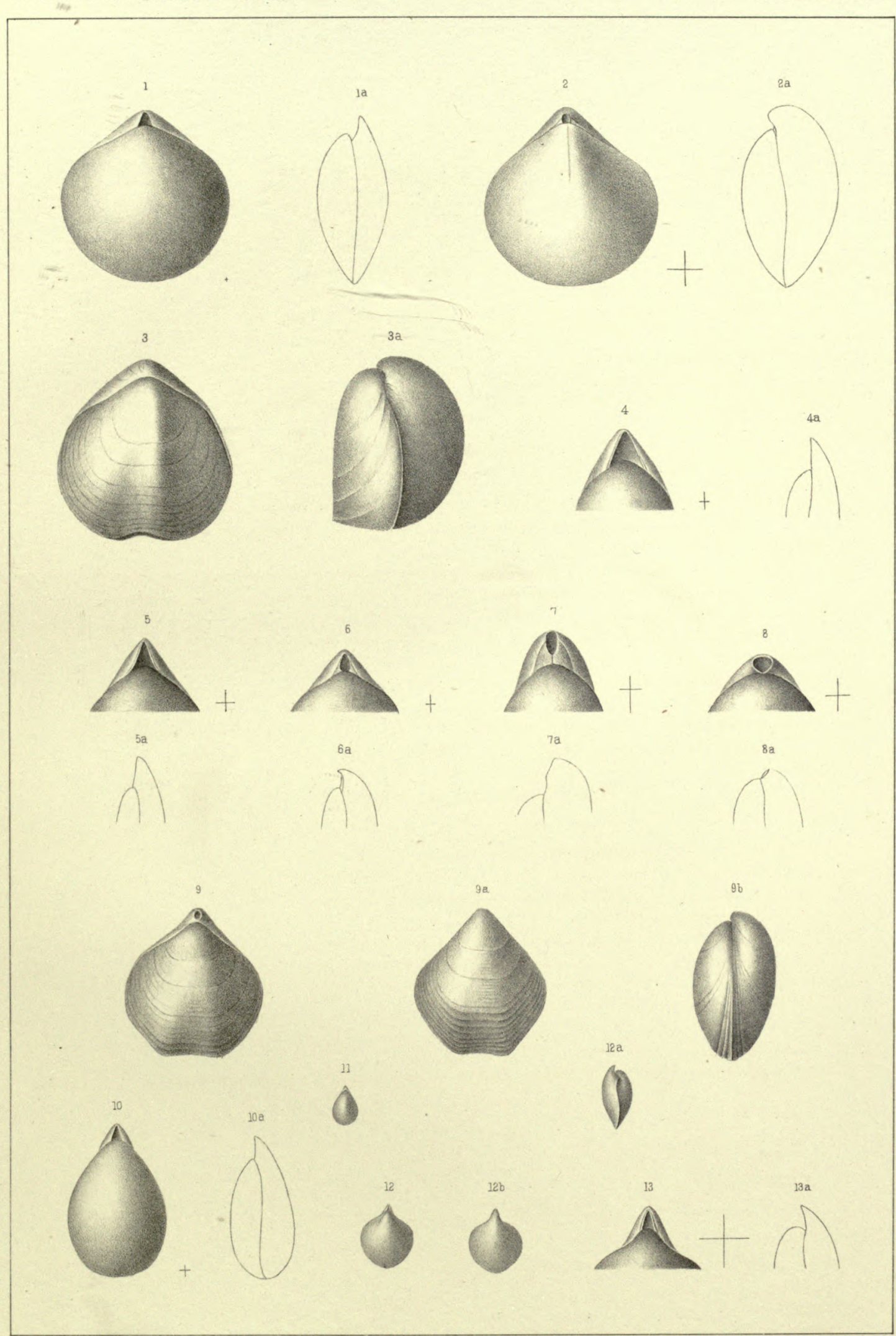

Philip Ast, lith,

Weed,Parsons \& Co. Albany, N.Y. 



\section{EXPLANATION OF PLATE VIII}




\section{PLATE VIII

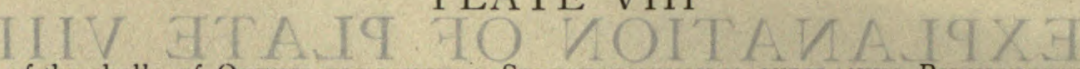

Series of the shells of Orthis elegantula, StreptorhynCHUS SUBPLANUM, RHyNCHOTRETA CUNEATA, and RETZia evax, from the youngest form observed up to the adult or senile condition. The plate has been drawn on stone from a photograph, and serves to show, not the details of structure, but the character and completeness of the material which has served as the basis of this work. 


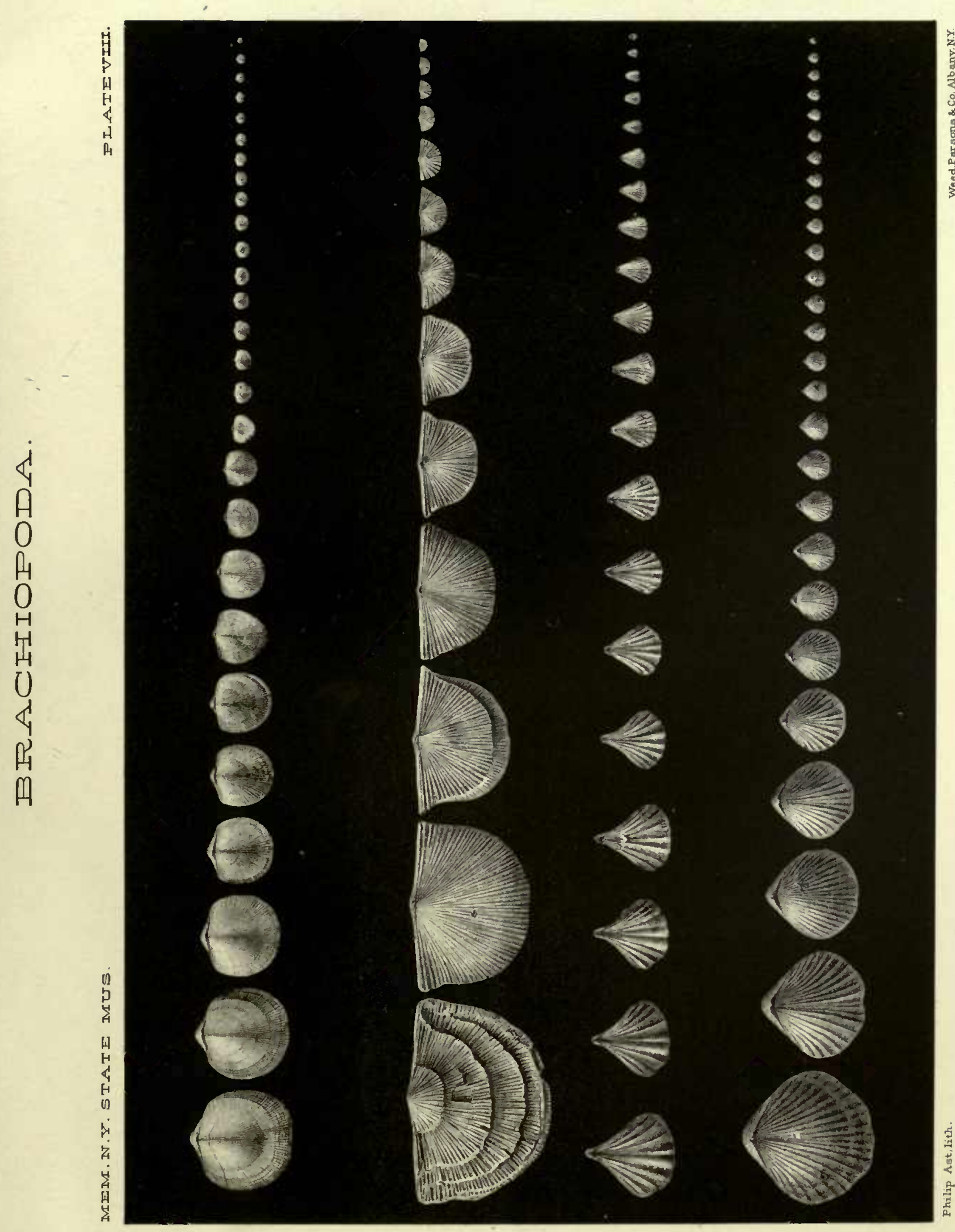




14 DAY USE

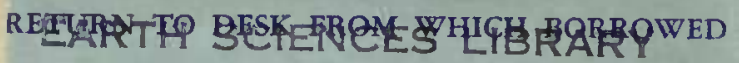

TEL: 642-2997.

This book is due on the last date stamped below, or

on the date to which renewed.

Renewed books are subject to immediate recall.

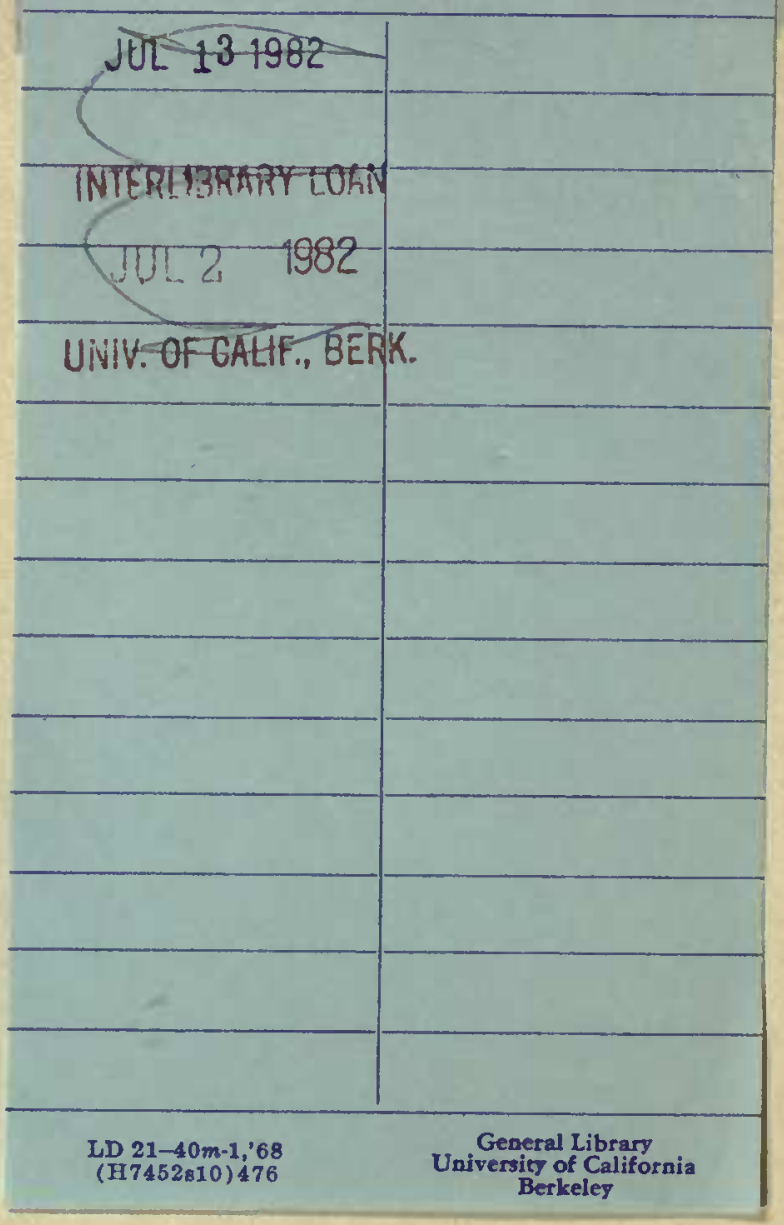



